\title{
Six day kidney preservation : combined hypothermic and normothermic perfusion
}

Citation for published version (APA):

Rijkmans, B. G. (1984). Six day kidney preservation : combined hypothermic and normothermic perfusion. [Doctoral Thesis, Maastricht University]. Rijksuniversiteit Limburg. https://doi.org/10.26481/dis.19840525br

Document status and date:

Published: 01/01/1984

DOI:

10.26481/dis.19840525br

Document Version:

Publisher's PDF, also known as Version of record

\section{Please check the document version of this publication:}

- A submitted manuscript is the version of the article upon submission and before peer-review. There can be important differences between the submitted version and the official published version of record.

People interested in the research are advised to contact the author for the final version of the publication, or visit the DOI to the publisher's website.

- The final author version and the galley proof are versions of the publication after peer review.

- The final published version features the final layout of the paper including the volume, issue and page numbers.

Link to publication

\footnotetext{
General rights rights.

- You may freely distribute the URL identifying the publication in the public portal. please follow below link for the End User Agreement:

www.umlib.nl/taverne-license

Take down policy

If you believe that this document breaches copyright please contact us at:

repository@maastrichtuniversity.nl

providing details and we will investigate your claim.
}

Copyright and moral rights for the publications made accessible in the public portal are retained by the authors and/or other copyright owners and it is a condition of accessing publications that users recognise and abide by the legal requirements associated with these

- Users may download and print one copy of any publication from the public portal for the purpose of private study or research.

- You may not further distribute the material or use it for any profit-making activity or commercial gain

If the publication is distributed under the terms of Article $25 \mathrm{fa}$ of the Dutch Copyright Act, indicated by the "Taverne" license above, 
SIX DAY KIDNEY PRESERVATION

combined hypothermic and normothermic perfusion 



\section{SIX DAY KIDNEY PRESERVATION}

\section{combined hypothermic and normothermic perfusion}

\section{PROEFSCHRIFT}

Ter verkrijging van de graad van doctor in de geneeskunde aan de Rijksumiversiteit te Maastricht, op gezag van de Rector Magnificus Prof. Dr. H. C. Hemker, volgens besluit van het College van Dekanen, in het openbaar te verdedigen in de aula van de universiteit op vrijdag 25 mei 1984 des namiddags te vier uur

door

Bernard Gijsbert Rijkmans

Geboren te Groningen 
Promotor: Prof. Dr. G. Koolstra

Referenten: Prof. F. O. Belzer MD PhD

Dr. A. J.M. Donker

Prof. Dr. H. A. J. Struyker Boudier

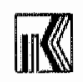

Zet-en drukwerk: Krips Repro Meppel

Het onderzoek werd mogelijk gemaakt door financiële steun van de Nier Stichting Nederland. (Subsidie C-163). Deze stichting en de firma Gambro, Nederland B.V. te Breda droegen bij in de drukkosten van dit proefschrift. 
Aan mijn ouders Aan Nienke 
VIrTON.

1. Kootstra $G$, van der Wijk $J$ and Rijkmans $B G$.

A new device toward intemediate term kidney preservation. An experimental study.

Scand J Urol Nephrol 54 (suppl): 86-89, 1980.

2. Van der Wijk $J$, Slooff MTH, Rijlmans BG and Kootstra G.

Successful 96-and 144-hour experimental kidney preservation: A combination of standard machine preservation and newly developed normothermic ex vivo perrifusion.

Cryoblology 17: 473, 1980.

3. Van der Wijk J, Voordes C, Rljkmans BG and Kootstra G.

Light microscopy findings in intemediate term kidney preservation.

Organ Preservation: Basic and Applied Aspects (Ed. DE Pegg, IA Jacobsen and NA Halasz), Lancaster: MIP press, p. 239, 1982.

4. Van der Wijk J, Rijkmans $B G$ and Kootstra G.

SIX day kldney preservation in a cantne model. Influence of a one to four hour ex-vivo perfusion interval.

Transplantation 35: 408-411, 1982.

5. RIJkmans BG, Van der Wijk J, Donker AJM, Sloof $\mathrm{MJH}$ and Kootstra G. Functional studies in 6 days successful preserved canine kidneys. J Urol 127: 163-166, 1982.

6. Rijkmans $B G$, Kootstra $G$, Van der Wijk $J$ and Nizet $A$. Intermediate ex-vivo and in-vitro perfusion to prolong hypothermic klaney preservation to 6 days.

Organ Preservation: Baslc and Applied Aspects (Ed. DE Pegs, IA Jacobsen and NA Halasz), Lancaster: MTP press, p. 267, 1982.

7. R1 Jkmans $\mathrm{BQ}$, Buruman $\mathrm{WA}$ and Kootstra $\mathrm{G}$.

S.x day canine kidney preservation: hypothermic perfusion combined with Isolated blood perfuston.

Treansplantation 37: 130, 1984. 


\section{CONTENTS}

PAPT I Introduction 9

Chapter I Review of literature

section 1 Normothermic perfusion 10

section 2 Cold storage 15

section 3 Hypothermic perfusion 20

section 4 Mechanisms of preservation fluids 31

section 5 Preservation at sub-zero temperatures 40

section 6 Combination of different preservation methods 45

section 7 The present thesis 47

PART II

Chapter II Materials and Methods 49

Chapter III SIx day hypothermic kidney preservation 55

Chapter IV Hypothermic perfusion combined with ex-vivo 69 perfusion

Chepter V Hypothermic perfusion combined with 1solated 83 blood perfusion

Chapter VI Modifled c1rcult for isolated blood perfusion 97

Chapter VII Hypothermic perfusion combined with 1solated 105

blood perfusion in modfled heart-lung machine:

Pilot studies.

Chapter VIII Hypothermic perfuston comblned with 1solated 109

blood perfuston in modifled heart-1ung machine:

Successful six day kidney preservation.

Chapter IX Blood flow durthg the intermediate blood perfu- 121 sion

Chapter X General discussion and conclusion

Sumary

Samenvatting

References

Slotwoord 



\section{PART I}

INTRODUCIIION

During the last fifteen years much researoh has been done in preservation of kidneys for transplantation. However no major improvements have been made since Belzer developed the hypothermic continuous perfusion in 1967 and Col11ns $1 \mathrm{n}-$ troduced the "cold storage" method in 1969. Nowadays k1dneys can be preserved satisfactory 24 to 48 hours by one of these basic techniques. This preservation time allows for tissue typlng, transport of the organ, preparation of the reclplent and the surgical procedure.

There are several advantages if long-term klaney preservation will be available. The shortage of donor organs can be reduced if less kidneys are discarded because the preservation time has exceeded safe limits. In addition more time w111 be provided for preparing the reciplent and for elective surgery. The introduction of new techniques in organ preservation may also enable improved viablilty testing of kidneys before transplantation. Moreover, further research in organ preservation may eventually lead to the ultimate goal of "organ banking", that has not been achleved as yet.

Much has been written about organ preservation. To give here a comprehensive review of the literature would be beyond the scope of this thesis. In chapter I an overview 1. presented of the development and current status of varlous methods for extracorporeal kldney preservation whlch are enployed in the clinlcal and experimental situation. Further, the subject of this thes $1 \mathrm{~s}$ w11 be introduced, $1 . e$. the comblnation of hypothermic- and nomothermic perfusion as a method for lntermediate-term kldney preservation. 
section 1: Normothermie pereuston

Throughout human history people have been interested in preservation of organs outside the body. In anclent Egypt (2700-1000 B.C.) most organs of human cadavers were carefully preserved and stored outside the body in vases (canopes). However, this kind of preservation took place as part of a mumiflcation procedure for magical-religious reasons and had nothing to do with sclentifle interest in living organs. In later dynastles, as reported by Herodotus (1), separate embalment of organs had been abollshed.

It was not before the nineteenth century that the first attempts at experimental preservation of $11 \mathrm{ving}$ organs were made from physlological polnt of view. In 1849 Löbel1 (2) Initiated the isolated perfusion of kidneys with defibrinated blood to investigate the process of urine formation. In 1881 Martin et al. (2) studied the activity of a heart-lung preparation. They succeeded in excluding the heart-lung circulation from the rest of the body by diverting the total cardiac output to the right auricle. In 1903 Brodie (3) deslgned an apparatus for isolated organ perfusion in which the oxygenation of the blood was effected by mixing it with air in 1 ts passage through the pump. However, In most of such experiments, especialiy in kidney perfusions, 1 t was difflcult to obtain a sufflelent flow rate through the organ. In 1912 Knowlton and Starling (4) slmpilfled and lmproved the heart-lung perfusion method of Martin. They succeeded In measuring the output of the left heart ventricle under nearly normal conditions. Hereby the amount of blood needed for one experiment was greatly reduced. This was an important contribution to the better quality of the perfusion.

In 1914 Balnbridge and Evans (5) employed the heart-lung preparation of Knowltion and starling for the perfusion of kldneys both in situ and 1solated. In this system, as opposed to the apparatus of Brodle, the kidneys seemed in a nor- 
mal functional condition and had a good blood flow so these conditions were more physiological although in thlo form of perfusion the investigation of the renal runotion was complicated by variations lnduced by metabolism of the heartlung preparation itself.

In 1920 Belt et al. (6) described the artiflolal perpusion of different organs and body tissues. They emphasized that different factors $1 \mathrm{~m}$ the perfusion procedure, such as composition of the perfusate, method of oxygenation, ischaemia and pressure were important in relation to injury to the perfused organ. The difference in results of the experiments between Brodie and Bralmbridge becomes more obvious by the work of Hemingway (7), who developed a lung-kidney preparation mechanlcally perfused by a pump. He demonstrated that deflbrinated blood, which had been stored for a while, caused vasoconstriction in the perfused kiney. The vasoconstriction properties of the blood disappeared within flve to ten minutes when $a$ lung was included in the perfusion circult. When a steady renal blood flow had been established, the lung could be removed without recurrence of vasoconstriction.

In 1957 Brull et al. (8) showed that also heparinized blood had vasoconstrictive properties when employed in artificial kidney perfusions. Since this vasoconstriction seemed to be the most limiting factor in the completely isolated kidney perfusion, N1zet, Cuypers and other coworkers of the group of Brul1 Investigated the olroumstances in which the vasoconstriction occurred. They detected vasoactive material in plasma of extravasated blood which had been stored for only a few minutes. The clrculation through an lsolated kidney could be blocked almost entirely by perfusion with blood that had been stored for 40 mlnutes (9). It was concluded that the vasoconstriction was caused by humoral factors whilon should be released malniy by erythrocytes (see also chapter IX). Moreover the traumaticaliy handing of the blood perfusate induced a more severe vasoconstriction $1 \mathrm{n}$ 
the perfused k1dneys. In additonal experiments cuypers and Nizet (10) lnvestigated the ablitu of different organs to neutralize the vasoconstrictive material. The r pesults confined the obserwation of Hemingway (7) that the vasoconstrictwe substances were eliminated or inactiwated by the lungs. However, this neutralizing efrect was also seen in the liver and in the kidney 1tselt. Taking into acoount these data, Cuypers and Mzet deslgned a signiflcanty $1 m-$ proved apparatus for lsolated kidney perfusion (11). With this device, approximately nomad kidney function could be achleved provided three important conditions were fulfilled $(12):$

a) The reduction of mechanical trauma of the blood was achieved by using a fllm oxygenator and a Dale schuster type pump with two 1 ight valves (13),

b) The perfusion stated Immediately after filling of the clrcult with fresh blood,

c) The amount of blood volume in tho perfusion machlne was kept Low and did not exceed $15 \mathrm{ml}$ per gram tissue weight. By fequert recirculation of the blood through the kidney, the released vasoconstricting material could be eliminated continuously. A more detalled description of this perfusion machine is given in Chapter $V$.

other or modifled techniques for nomothemie blood perfusion of 1 solated kidneys were descmibed by several authors $(14,15,16)$. Rosenfeld et al. (17,18) achieved satisfying function in rabbit kldneys by using whole heparinized blood In an entinely plastic perfusion system including a film oxyenator. Berkowltz et al. (19) obtalned good results in perfused canine kidneys: 1njury to the heparinlzed blood was reduced by employing a sillcone rubber circult and a membrane oxygenator. Waugh and Kubo (20) descmibed improved function In isolated dog kidneys. In their perfusion apparatus with a fllm oxygenator, normal blood flow rates were measured within the first hour of the perfusion although, as distinet from one of the prineiples mentioned by cuypers and 
Nizet, they used defibninated blood that had ben stored up to 1.5 hour.

Although some of the main problems in momothermic perfuston of 1 solated kidneys have been solved certaln dratbacks remain. After 2 to 3 hours 1 salated perfusion, a progressive loss of vascular tone, a decrease of glomerular filtration and a dissipation of urine acidification are observed (21). Momeover alterations in the Intrarenal blood flow distribution in favour of the medulla are probably responsible for an increasing loss of concentration ability of the kidney (22).

To avold the difficulties inherent to blood perfusions several investigators $(23,24,25)$ perfomed nomothemic 1 solated kidney perfusions with an artiflclal cell-free perfusate. These perfusions are best sulted for kldmeys of small amimals and yield satisfying results in metabolic and pharmacologic studies. Very high perfusate flow rates commonly observed in these perfusions are due to the low viscosity of the cell-free perfusate. However, other physlologlcal functions of cell-free perfused kidneys seem to deteriorate more rapidly than in blood perfused organs. Within two hours Bahlmann et al. (23) found a decreasing glomerular flitration rate (GFR) and a low sodlum and water reabsorbtion in isolated rat kidneys perfused with a bovine-albumin solution. Ross et al. (24) showed improved abllity of sodium reabsorbtion in rat kidneys by the addition of sucose as substrate to a dialyzed albumin solution. Fuller et al. (25) obtained GFR values within the normal range by using pluronic F108 as collold in two hours perfused rabolt klaneys. In all these cell-free perfusions, a hjgh oxygen pressure was malntained in the perfusate.

Another approach to achleve adequate oxygen supply in normothermic bloodless perfused organs ls the use of fluorocarbon. Micro-emulsions of fluorocarbon particles (two to three micron), whlch can be considered as artiflclal erythrocytes, have a high oxygen-carrylng capac1ty. Kowalewsk1 
et al. (26,27) described luorocarbon perifusion of isolated gatroduodenopanoreatio preparations in dogs which naintained secretory function up to flve hours. However, Endrich et al. $(28,29)$ showed that fluorocarbon emulsions had a detrimental effect on microcirculation and endothelial cells, unless used in small concentrations. Dunn et al. (30) perfused dog klineys whth fluorocarbon emulsions up to 18 hours. In these perfusions the loss of organ viablilty was related to swelling and considerable weight gain (>50\%) in combination with increasing vascular resistance.

Oxygen transport in extracorporeal organ perfusion can also be obtained with stroma free haemoglobin (SFH) solutions. In these perfuslons the free haemoglobin does not only play a role in oxygen delivery but also creates collold osmotic pressure. Schrier et al. (31) reported sufficient oxygen release in 1 solated dog kidneys perfused with a $6 \%$ SFli solution. However, during six hours perfusion they found a continuing decrease in perfusate flow rate. Mistological examination of the kidneys demonstrated haemoglobin deposits in the glomerul1. Suaudeau et al. (32) described isolated lamb heart perfusions with an $8 \mathrm{~g}$ SFH solution for eight hours. In their experiments the addition of plasma-proteins was essent1al for a good functional and morphologic preservation of the heart.

It can be concluded that sofar the functional integrity of an 1solated organ cannot be preserved longer than seven hours by one of the described methods of nomothermic perfuslons (33). Lack of substrates, hormones and oxygen supply, the cumulation of waste products and damage caused by the mechanlcal way of perfusion are all factors which may be responsible for this fallure. Therefore organ preservation by only nomothermic perfusion seems to be unsuitable for application in transplantation procedures.

Some investigators $(34,35,36)$ have used normothermic perfusions to assess the viablilty of kidneys after different methods of preservation. A new application of normo- 
thermic perfusion in kidney preservation w11 be 1 introduced at the end of this chapter.

section 2: Cold storage

In the early sixties cadaver kidneys were used for the first time in human transplantation (37). A reliable method was necesiary for preservation of the organ whlle the prospective recipients were prepared for surgery.

It was known by experiments of Lefèbre and N1zet, published in 1952 (38), that after intial cooling by brief perfusion with a "physiologlcal" solution, kidneys could be stored up to 24 hours at low temperatures. After autotransplantation the kidneys recovered functional activity. In 1959 Levy (39) demonstrated a marked but reversible reduction of oxidative metabolism in hypothermic perfused dog kineys. So the use of hypothermia seemed to be an attractive and simple appoach for practical organ preservation.

In 1963 Calne and PegB (40) described experiments in which the influence of simple surface cooling on dog kidneys was studied. After perfusion with $20 \mathrm{~m} \mathbb{1}$ of heparimlzed blaod the kldneys were stored at $4^{\circ} \mathrm{C}$ in a Hanks' solution for periods up to 24 hours. Kidneys preserved for 12 and some up to 17 hours had 11 fe-sustaining function after implantation followed by lmmediate contralateral nephrectomy. "The preservation time could be extended successfully to 24 hours $1 t^{\circ}$ the kidneys were perfused with cold arteriel blood prior to surface cooling. The cold blood ltself seemed to protect the kidney for 1 schaemia, because in the perfusion experiments of Calne the coollng rate was the same as in those w1th surface cooling alone. Mhis was due to the additional techndoal manipulations required in the penfusion with cold blood (41).

To investigate further the effect of rapld cooling low molecular weight dextran solutions were used. However, after 
24 hourg preservation no Ifre-sustalning kidney function was observed. Hstological examination of these kidneys showed hyaline deposits in the glomeruil.

Simliar histological findings were reported by kiser et al. (42) using dextran solutions for rapld cooling of dog kldneys collowed by surface cooling. In their serles they obtalmed life-sustaining kidney function arter seven to eight hours preservation.

Arother method of intial flushing with subsequent cooling wa described by Brunius et al. (43). The preservation method of kidneys obtalned from cadaver donors involved three stages:

a) Infection of a vasodilator and an anticoagulant in the renal artery,

b) flushlng of the organ with a 5\% low molecular welght dextran solution at $5^{\circ} \mathrm{C}$,

c) cold storage after perfusion with a solution containing equal amounts of $10 \%$ fructose and $1.4 \%$ sodium blcarbonate.

Elght out of 46 kidneys, preserved by this technique up to seven hours, never functioned. In dog experiments the authors obtalned satisfactory preservation up to 20 hours using this procedure. In Europe this technique has been used in clinical preservation for some years.

In 1966 Keeler et al. (44) described some Important experiments. They analysed the changes in water, sodium, potasslum, magnesium and phosphate content of rat kidneys af ter perfusion with a physlologlcal solution of sodium chloride at $0^{\circ} \mathrm{C}$. After three hours perfusion a considerable increase in tissue- water and sodlum was measured. Tissue potassium content decreased rapldy whereas loss of tissue magneslum was only observed during the third hour. No loss of phosphate occurred in any perfused kidney. The mechanisms (a.o. slowing down of $\mathrm{Na} / \mathrm{K}$ pump at low temperatures) responsible for these lon and water shifts w11l be discussed in section 4 of this chapter. 
To pind out if the damage caused by the diffusion of water and electrolytes across the cell membrame could be prevented, Keeler et al. used perfusates containing high concentrations of potassium and magnestum. After three hout perfusion of dog kidneys at $0^{\circ} \mathrm{C}$ followed by implantation good renal function was observed. The idea to use intracellular-11ke solutions was elaborated further by collins et a1. (45). Dog kianeys were flushed with 100 to $150 \mathrm{ml}$ of vam rious cold solutions with an intraceliular composition and stored for 24 to 30 hours at $4^{\circ} \mathrm{C}$. After Implantation and $1 \mathrm{~m}-$ mediate contralataral nephrectorn, the animals survived with excelient renal function. The composition of the varlous preservation flulds 15 listed in Table I, I. The solution without glucose $\left(\mathrm{C}_{1}\right)$ caused swelling and low perfusion-rate of the kidneys. Preservation with this solution was not superior to simple surface cooling. The $C_{2}, C_{3}$ and $C_{4}$ solutions protected the kidney adequate for hypotherma. Good results were achleved in clinical preservation of cadaver kidneys up to 12 hours using the $c_{3}$ solution (46). However, the additives procaine $\left(\mathrm{C}_{3}\right.$ and $\left.\mathrm{C}_{4}\right)$ and phenoxybenzamine ( $\mathrm{C}_{4}$ ) were found to be harmful for short periods of hypothermio storage (47,48), whereas the addition of heparin seemed to be of I1ttle value. In other experiments collins et al. (49) studied the influence of changes in cation composition on the efficacy of the preservation fluld. In presence of $\mathrm{MgSO}_{4}$ the exchange of $\mathrm{K}^{+}$by $\mathrm{Na}^{+}$in the preservation fiud was equally effective in the preservation up to 24 hours. This Indlcated that the beneflcial effect of the collins solution was not due to 1 is intracellular like composition. However, a high potassium content did have a beneflicial effect in preservations with solutions free of magnesium. Apparently magneslum prevented loss of 1 ntracellular potassium.

Lateron collins et al. (50) investigated the role of the anson content and the osmolarity of the flush solutions. They demonstrated that the presence of osmotically active, non-diffustble anions (phosphate) and non-electrolytes ( $\mathrm{B} I \mathrm{-}-$ 


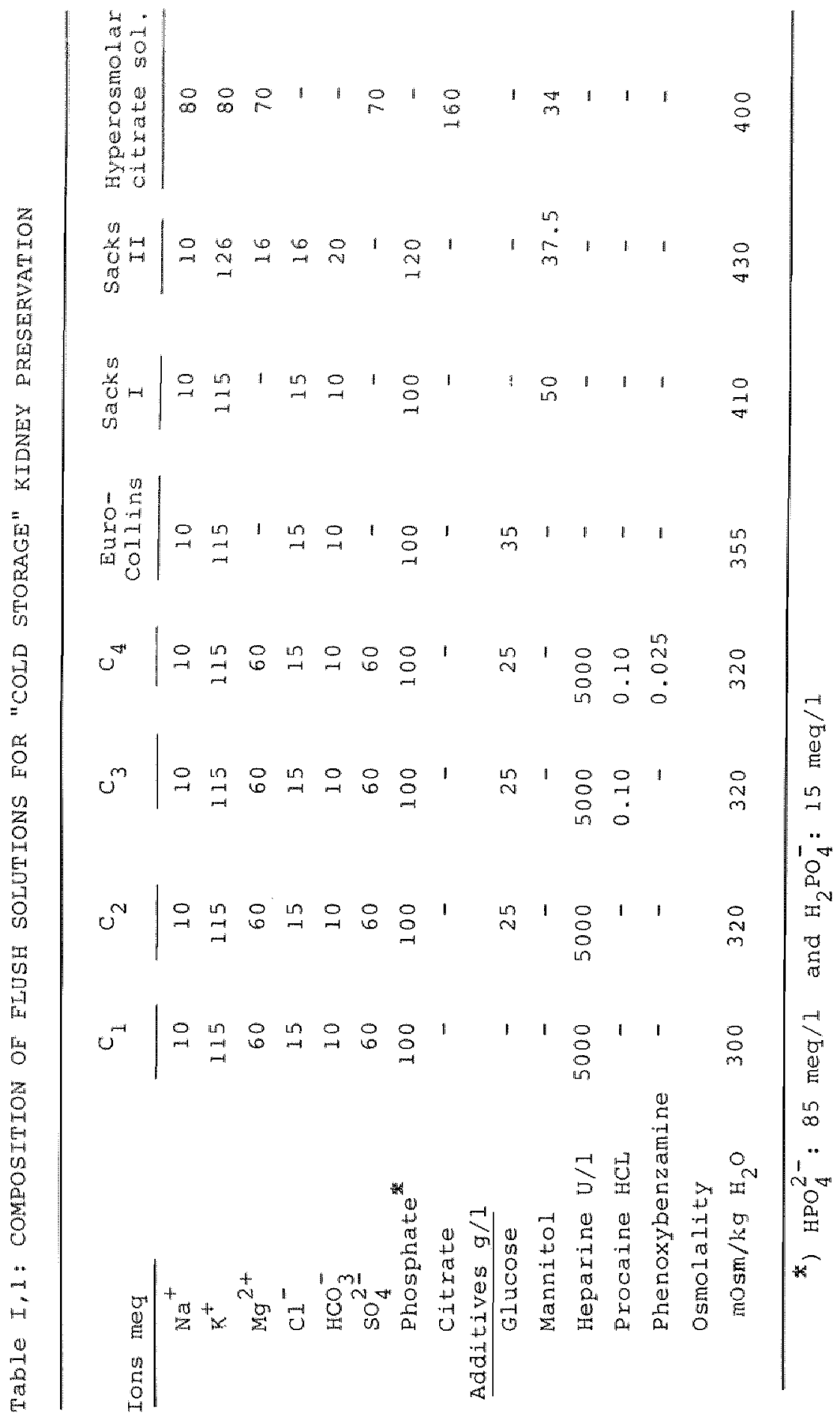


cose) was of major importance in the prevention or cell. swelling under hypothemic conditlons (see section 4). The "Collins-solutlons" are now widely used in ollndeal peservation. Watkins et al. (51) showed that similar solutions without magneslum-sulphate ylelded equally good results in 24 hour preservation of dog kidneys. This stmplifleation of the preservation fluid prevents the preclpltation of magneslum-phosphate which might cause vascular occluslon $(52,53)$. Sunce 1976 most centres of the Eurotransplant organisation obtain satsfactory results in clinical preservation using a madified Coll1ns solution. This "Eurocolilns"-solution (Table I, I) (54) contalns no magneslum and has an 1ncreased osmolarity by the use of a higher glucose concentration.

In 1973 sacks et al. (55) Introduced a new renal perfusate whlch was successfully used in preservation of canlne kidneys up to 72 hours. Remamably good results were obtalned In 48 hour preservation of dog kidneys whlch had suffered 30 minutes warm ischaemia in situ before perfusion with the flush solution. The solutions had also an intracellular Ion composition and were nade strongly hyperosmolat with mannito1: one solution (Sacks I) was free of magneslum and the other (Sacks II) contained magnealum in the form of $\mathrm{MgCl}_{2}$ (Table I). These solutions proved to be also sultable for preservation of kidneys at nomothermia allowing two to three hours "work-bench surgery". Particularly in the protection for wam lohamia the Sacks" solutlons were superor to the Collins solutions, which falled in 24 hour preservation of kldneys exposed to 30 minutes of warm lschaemla (56). However, other authors were not able to reproduce these favourable results. Some Investigators $(57,58)$ could not preserve canine kldneys with Sacks' solutions por periods longer than 24 hours.

In 1976 Rosis et al. (59) described successful 72 hour preservation with a hyperosmolar cltrate solution whlch differed from the intracellular solutions employed by collins 
and Sacks. The good results obtalned wth thls solution (Table 1,1$)$ clearly demonstrate that a high osmolarity and the presence of slowly permeable lons are of more importance than an "Intracellular" composition (see section 4). However, other authors $(60,61)$ have not been able to reproduce these results.

In 1978 poledo-pereyra et al. (62) introduced a collotid hyperosmolar solution with high concentrations of proteins, potassium and glucose. Th1s solution was found to be superior to sacks II solution in 24 hour preservation of dog kidneys with a preceding warm ischaemia time of 30 to $60 \mathrm{mi-}$ nutes.

It can be concluded that most of the cold storage solutions, which have been discussed, can be safely used for preservation up to 36 hours. Among several investigators different and reverse results are obtalned when these flushing solutions are used for preservation periods of 48 to 72 hours. A conslderable warm ischaemia time antecedent to hypothermic storage greatly reduces the efflcacy of the flush solutions. The mechanisms which might be responsible for thls fact will be discussed in the next section.

section 3: Hypothermic continuous perfusion

In the early stages of kIdney preservation most attention was pald to hypothermic continuous perfusion of the organ. Indeed this technlque has some advantages above cold storage.

In 1959 Levy (39) demonstrated that in perfused kidneys hypothermia induced a reduction in oxygen consumption which was proportional to the centrigrade temperature. Hence, cell metabolism and so the need for substrate and oxygen supply are not completely abolished under hypothermic conditions. Burg et al. (63) Indlcated that even at $0^{\circ} \mathrm{C}$ an active transport of cations can be detected in renal tubular cells. This 
persistence of active ion transpont at low temperatures was confirmed later by Lambotte (64). Therefore 1 t seems to be most likely that only a continuous perfusion can account for the cell requirements under hypothermia. The method of hypothermic continuous perfusion was pirst described by Humphries et al. In $1963(65,66)$. They perfused dog kidneys with $50 \%$ diluted blood at $10^{\circ} \mathrm{C}$ for 24 hours. After autotransplantation five out of seven kidneys had 11fe-susta1ning function. The perfuston clrcult included a glass wool rilter and a membrane lung. In a few experiments successful three day preservation was achleved (67).

In 1967 Belzer et al. (68) were the first who described consistent successful results in 24 and 72 hour hypothermic continuous perfusion of canine kianeys. Essentially their perfusion circult resembled that of Humphries', but as perrusate they used cryopreclpitated plasma obtained from c1trated blood to which magnesium sulphate, dextrose, Insulin, pentcilin and hydrocortisone were added (Table I, 2). In this cryopreclpitated plasma flocculations of lipoproteins, generated by a procedure of freezing and rapid thawing, were removed by microflitration. Preservation of canine kldneys for 72 hours using the Belzer technlque was also described by Woods in 1971 (69). However, his experiments were only successful if $250 \mathrm{mg}$ methylprednisolone was added to one 11tre of perfusate. Abouna et al. (70) were not able to obtain good results unless the amount of perfusate $(600 \mathrm{ml})$ was exchanged by fresh cryopreclpltated plasma at 12 to 16 hour intervals during the three day preservation period. He sug gested that high levels of ammonia concentration up to 1.5 mmol/L measured in the perfusate were responstble for fallure when the perfusate was not exchanged. Indeed in vituo studies of Preuss and Murdaugh (71) have Indicated that ammonia is a toxic substance to renal tubular cells. Abouna perfused the canine kidneys at 12 to $14^{\circ} \mathrm{C}$ whereas Bellzer perrused at $8^{\circ} \mathrm{C}$. The higher temperature might explain the rapld accumulation of waste products measured by Abouna. 


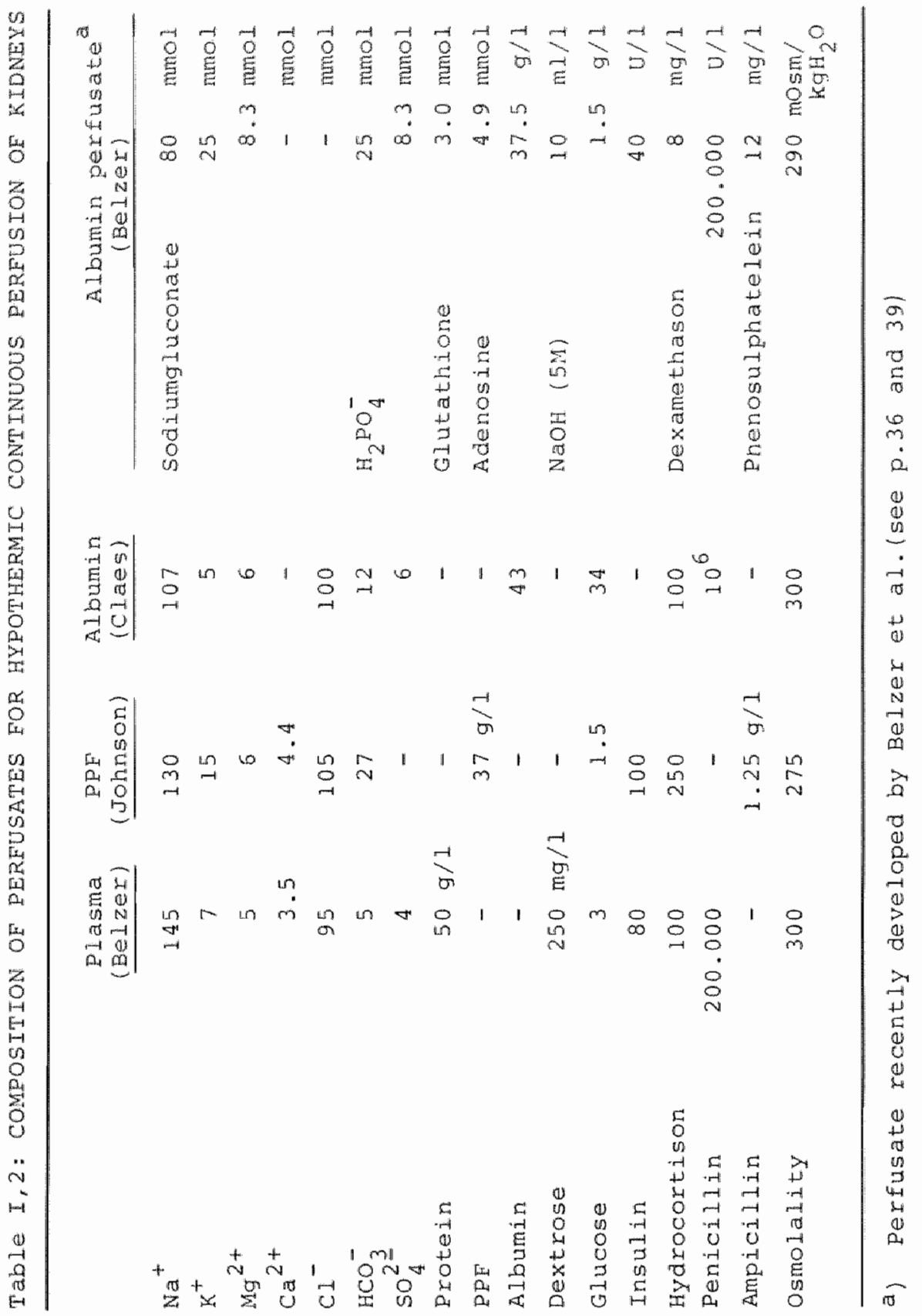


These observations were conflmed by Grundmann et a1. (72)* They achleved successful hypothermic continwous perfusion up to 96 hours by exchangling the perfusate volume of $1200 \mathrm{ml}$ every 24 hour. Good results were also obtalned when the perfusate volume was doubled and not exchanged during the preservation period. However, a controlled study of Willians et al. (73) showed equally good results in 24 hour canine kidney preservation with a perfusate which had been already used for 72 hours.

In 1972 Johnson et al. (74) Introduced a new perfusate containing plasma protein fraction (PPF). PPF is prepared by extracting heat-labile fibrinogen and gamma-globulin from plasma; subsequently the remaining heat-stable proteln solution is incubated at $60^{\circ} \mathrm{C}$ for ten hours to 1nactivate evertual serum hepatitis agent. Their perfusion apparatus inoluded a pulsatile pump and a disc-oxygenator. The perfusion was carried out at $6-3^{\circ} \mathrm{C}$ with a total perfusate volume of $500 \mathrm{ml}$. Using this PPF solution (Table $\mathrm{I}, 2$ ) good renal function was observed after 72 and 96 hours preservation (75).

In 1972 Claes and Blohmé (76) described successful 72 and 96 hour hypothermic continuous perfuston using a human albumin (KablVitrum) containing perfusate (Table I,2). Dog kldneys were perfused with 0.8 litre of this solution at $6-10^{\circ} \mathrm{C}$ in a Gambro ${ }^{(B)}$ machine including a roller pump and inftially a membrane oxygenator. However, in preservation experimentis up to 96 hours equally good results were obtalned when the membrane oxygenator was onltted and the oxygenation was established by blowlng the gas mixture above the surface of the perfusate in the organ chamber. This simpliflcation was also applied by Johnson (77).

In 1974 Abouna et a1. (78) described 24 hour hypothermic perfusion in dogs. In four experimental groups they compared cryoprecipltated plasma and albumin using pulsatile and nonpulsatile perfusion. Although the overall survival was similar in all groups, better perfusate flow characteristics were obtalned with albumln perfusate using elther pulsatile 
or not-pulsatile perfusion. Kineys perfused with plasma showed hlgher perfusate flow and beter function 1 mmedlately after lmplantation when pulsatlie perfusion had been used. In 1974 Toledo-Pereyra et al . (79) Introduced a perfusate contaln1ng silloa gel-treated plasma, which was found to be superior to cryopreclpltated plasma. By the sillea gel treatment all cholesterol, lipoprotelns amd florinogen are removed.

The flust alnical applications of hypothermic continuous perfusion was reported by Belzer et al. (80). Slnce that time this technlque has been widely used in preservation of human cadaver kldneys up to 3 days using elther cryopreclpitated plasma $(81,82,83)$, plasma protein fracton (84,85) or albumln $(76,86,87)$. Recently, Belzer et al. (88) obtalned very good results with a new albumin perfusate contalning a.a. sodium-gluconate, adenosine and phosphate (Table $I, 2)$.

In hypothermic kidney preservation there has always been a klnd of "cold war" between followers of the cold storageand the continuous perfuston technique. In 1969 Coll1ns 1ntroduced his preservation solutions as a counterpart of the "bulky, complex and expensive Belzer apparatus". Send1ng dog kidneys alt over the world (45), he gave more information about the slze of the Belzer machlne at that time, than about the quality of hls own preservation solutions. As mentioned before, simplifications in the method of pumplng and oxygenation ald not lnfluence the results of hypothermic contunous perfusion. By these contributions the development of much smaller perfusion systems was possible $(76,89,90)$. Today portable perfusion machlnes contalning disposable organ-chamber cassettes are commercially avaliable. These machlnes can be handled easliy by one person and are sultable for transport by alr. of course, form a practical polnt of view, perfusion preservation still remains more laborious than cold storage. However, there are several more important differences between these two technlques which may be relevant for the cholce of the best suited method for clinical. 
preservation.

There has been some controversy about the question whewher the method of preservation Influences the long term graft survival in clinloal klaney transplantation. Im a multicentre study opelz and Terasaki (91) lndicated that the overall survival rate of cold storage klaneys was slgniplcantly higher than in the perfused Broup. In this study the two groups are not strictly comparable since the cold storage group had a mean preservation time of nine hours as opposed to 23 hours in the perfused group. In the pereused group an unusual low Immedlate function rate (45\%) was reported. This mag be due to technical errors in the use of preserwation machines. Centres. with high experience in perfusion techniques obtalned immediate function rates up to $80 \%$ (92) and In their serles long term graft survival was slmidr or even improved after perfuston preserwation $(93,94,95)$. In another more recent study opelz and Terasak1 (96) reported superior one month and one year graft survival of human atdaver kidneys, preserved by cold storage up to 48 hours, with or without a preceding warm 1schaemia time up to 60 minutes. Hypothemic continuous perfusion was only better in kidneys preserved for longer than 48 hours. From this study they concluded that cold storage was superior to contlnuous perfusion. However, $1 t$ must be admitted that the percentages of one month and one year graft survival mefer only to the rate of rejection. The lmmediate kidnew function arter transplantatilon would be a better parameter to evaluate the preservation technique. Rather one might conclude from the study of opelz and Terasaki that k1dneys preserved by perrusion techniques are $11 k e l y$ to be rejected. Several authors (97,98) have reported endothellal damage and denud1rg of" the basement membrane following perfusion preservation. This perfusion nephropathy may "unmask" antigentc sites and thus accelerate allogrart rejection. Perfusion nephropathy ltsel $1 \mathrm{~s}$ morphologlcally 1dent1cal to hyperacute rejection (98). This perfusion-related injury can vary from minute breaks in 
the glonemiar endothelim to complete denudation of the basement membrane. Afier transplantation the exposed collaGen activates the clotting sequence resulting in platelet, florin and white cells deposition ln glomerular caplilary loops, whereas ln the hyperaute relection the triggering mechanlsm 1 s cytotoxlc reciplent antibody.

In an experimental study cerra et al. (99) showed that endothellal damage induced by perfuslon preservation could be minimized by $1 \mathrm{~s}$ lng $10 \mathrm{w}$ perfusion pressures and perfusates with hith collold osmotic pressure. Perfusion nephropathy was not observed by van der WIJk et al. (100) in dog kidneys preserved for 96 and 14 h hours. In these experiments a low perfusion pressure (20 $\mathrm{mm} \mathrm{Hg}$ ) and an albumin perfusate were used.

A general approved difference between cold storage and hypothermic continuous perfusion 1 the ablity of perfusion technlques to preserve kidneys which have suffered a considerable time of warm lschaemia. This was clearly shown by Johnson et al. (101). After 60 minutes af warm 1schaemia dog kilneys were perfused for 24 hours. All these kldneys returned to nomal function within two weeks following autotransplantation. On the other hand kidneys preserved by cold storage for 24 hours did not function if the preceding warm ischaemia time exceeded 30 to 40 minutes.

These observations have been conflrmed by Halasz (102) who reported guccessful 48 nowr perfusion preservation in dog k1dneys exposed to 20 minutes of warm 1schaemia. No surVIVal was obtalned after preservation of ischaemic damaged kldneys w1th Col11ns or Sacks solutions. Denham et al. (103) also described Improved results with continuous perfusion after warm 1schaemia. Moreover In these experiments comblnatlons of perfusion and cold storage were superior to cold storage alone, but infertor to continuous perfusion. In k1dneys subjected to prolonged perlods of warm Ischaemia, Johnson et al. (56) observed an increased vascular resistance duning hypothermic continuous perfusion, which was propor- 
tional to the warm ischaemia interval. This was evidenced by Low flow rates of the wash-out solution and higher perusion pressures. During the itrst 12 hours of the hypothemid oontinuous perfusion, the pressure decreased to values measured In kidneys preserved without antecedent wam ischaema. The intelal wash-out was less effective since the perfusate was stained with bload. Johnson et al. concluded that the contnuous perfusion had further opened up the renal circulation. Kidneys injured by warm lschaemla and preserved by cold stomage for 24 hours were not completely refilied with blood ater relmplantation. This so-called "no-reflow" phenomenon after renal 1 schaemia was plrst described by Sheehan and Davis (104) in 1959. The posstble mechantsm of this "no-reflow" phenomenon can be explained by the work of several inwestigators.

Flares et al. (105) observed swelling of endothellal cells after 60 minutes of warm lschaemia in rat kidneys. They suggested that during anoxia depletion of ATP 1 ractivated the sodium pump In the cell membranes, causing perivascular cell swelling and flnally vessel blockade.

Summers and JamLion (106) demonstrated perfusion defects In rat kidneys subjected to 60 minutes of warm 1 scharema by perfusion of the renal artery with carbor particles (600A). When the renal vessels were emptied of blood by sallne flushing prior to the warm 1schaemia, the carbon distrlbution was similar to that in non-1schaemic kidneys. on the other hand, If saline flushed kldneys were reperfused with blood, the "no-reflow" phenomenon occurred. This suggested that the caplliary lumina were too narrow to permit passage of red cells but large enough for the much smaller carbon particles. These authors also showed that the endotheldal cell swelling could not account entimely for the "no-refllow" phenomenon. Large perfusion defects, present in blood-f1lled kldneys subjected to only 15 minutes warm ischaemia, were prevented if heparin was glven before clamplng of the remal vessels. It was suggested that in absence of heparln, f1- 
brin-dependent rouleaux formation of erythrocytes and fibrin clots might contribute to caplliay ocolusion. However, anteoagulation with heparin did not prevent the "no-replow" phenomenon after 60 minutes of warm ischaema. This might be due to the decrease in $p H$ calsed by anaeroble metabollsm $1 \mathrm{n}$ the anoxlo renal tiseue. Hardaway et al. (107) have shown that heparlin la less effective at low pH levels. Another mechandsm which might also cause the "no-reflow" phenomenon was described by Weed et al. (108). Wam lschaemla not only Induces ARP depletion in endothellal and tubular cells, but a.so $1 \mathrm{n}$ blood cells stagnant in renal vessels. These invest1gators demontrated a decreased deformability in ATP depleted red-cells. They suggested that in absence of ATP, which nommally chelates calolum, the cell membranes become more rigla by calcium blnding to membrane proteln. These rlgld cells could be easlly trapped in caplliarles of Ischaemic kldneys. The calclum binding could be lnhiblted competitively by $\mathrm{Mg}^{2+}$; this would explain the beneplc1al effect of $\mathrm{Mg}^{2+}$ in wash-out solutions and perfusates. Bergstrom et al. (109) described rapld decrease of ATP levels $1 \mathrm{~m}$ dog K1dneys durlng 20 minutes warm ischaemia. After 24 hours of hypothermic continuous perfusion the ATP levels of those kldneys were 1ncreased, whereas a further decrease was observed $1 f$ the kidneys were preserved by cold storage w1th Collins solution. The data described by these authors glve a plablble explanation for the decrease in the high vascular reslstance in lschaemlc damaged Kldneys durlng hypothermio continuous perfusion.

Clinlodily the experimental evidence has been conflrmed that perfusion 1 s aperior to cold storage in kidneys subJected to wam 1schaemia. Slooff et a 1 . (110) reported a bicher percentage of limmediate function in klaneys obtalned prom non-heart beating donors preserved by continuous perfuslon compared to those preserved by cold storage.

It can be concluded that hypothermic continuous perfusion 13 a rellable method for preservation of kidneys up to 
72 hours. Moreover perfusion preservation should be the method of cholce for kidneys which have suffered constderable time of warm ischaemia.

\section{VIABILITY TESTS}

It would be a great advantage to have the disposal of reliable tests predicting the viability of cadaver kidneys before transplantation. In this respect the history and pretreatment of the donor may be important.

Belzer et al. (111) described the detrimental effect of renal vasospasm in the donor due to shock in the agonal period. After transplantation of these kidneys a high incldence of acute tubular necrosis was observed. Even in cadaver kidneys with minimal warm 1 schaemia this vasospasm caused Insuffletent wash-out and high perfusion pressures during preservation. Excessive manipulation and traction on kidneys during nephrectomy could also induce vasoconstriotion. Belzer emphasized the need for adminlstmation or phenoxybenzamine to the donor before cardlac arrest to prevent this vasoconstriction. Filoso et al. (112) have confirmed the importance of cadaver donor pretreatment with vasodilating arugs.

In kidneys harvested from heart-beating donors under optimal conditions, a high flow rate of initial wash-out is generally correlated with good viablitty arter preservation up to 24 hours with Collins solution. Kidneys obtalined from non-heart beating donors are mostly selected for hypothermic perfusion. It will be obvious that this preservation technique offers the opportunity to evaluate certain mechandcal and biochemical parameters durlng the preservation perlod. Clinical (81) and experimental (103) data indicate that low perfusion pressures and high perfusate flow rates during the Initial phase of the preservation period tend to correlate well with viablity after transplantation. However, low pressures and high flow rates measured during later phases 
of perfuson are not reliable in predicting renal runction. Ihls was shown by proctor (113). In lreversibly damaged dog kidneys he observed Initial high vascular resistance. After 12 to 24 hours these pressures decreased to values within the range of undamaged control kidneys. This equal resistance may be explatred by a changed pattern of corticomeduliary flow as observed by M11er et al. (114) In kidneys subjected to warm 1schaemla.

In thelr Intw1al studies Johnson and Baxby $(56,115)$ showed that a decrease in pH and rise in lactate levels in the perfusate during the first hour of perfuslon correlated with the viability arter 24 hours preservation. Throughout the remalning preservation period these values did not change very much. Lateron they argued that the lactate level was only sulable to assess the extent of lnjury by wam 1schaemia. Further deterioration of the kidney during perfusion was found to be related to the release of N-acetyl glucosaminidase (NAG), a tubule-speciflo lysozomal enzyme (75). However, the tubular release of NAG could not reflect the prosence of Glomerular lestons observed in kidneys preserved for 5 to 8 days $(77)$.

Gundmann et a1. (116) described good correlation between lactic dehydrogenase (LDH) concentration in perfusate and vlablitty of dog kidneys subjected to 30 minutes of warm 1schaemla prior to hypothermic perfusion up to 72 hours. In their serles the LDH concentration correlated not only with the lenght of warm lschaemia but also whth the duration of perfusion. Other authors (Johnson and Belzer) have obyections to LDH as predictor of viablitty. In some kldneys with hlgh perfusate levels of LDH, they observed good renal function after transplantation. An 1regular release pattern of LDH, which is a cytoplasmic enzyme, could explain the large owerlap in perfusate levels of LDH between viable- and nonWable kidneys. In a retrospective study Modg11 et al. (117) evaluated some vlabl11ty tests in cadaver k1aneys preserved by hypothermic continuous perfusion up to about 24 
hours. No significant difference in pH, LDH or free fatty acld levels could predict kidney fumotion after transplantation.

Feinfeld et al. (118) showed that high perfusate levels of ligandin, an enzyme having gluthathione s-transferase activity, correlated with damage of the proximal tubule after transplantation. Recently this finding has been conflmed by Cho et al. (119).

However, in conclusion it can be said that the prediction of viablity is not likely to be correlated to the change of one single factor. The injury on preserved kldneys, belng complex and multifocal, should be evaluated by all disposable data: the history of the donor, the method of preservation, perfusion characteristics and blochemical parameters. In combination with the duration of the preservation perlod, these factors will allow a more rellable assessment of viablitty after transplantation.

Section 4: Mechanisms of preservation flulds

In preservation technlques as described in section 2 and 3 , the vascular and Interstitial space are fliled with preservation fluld. The interaction between the extracellular and Intracellular space may be described by the following approach.

Some blilions of years ago life on earth began in the primordal ocean. It has been proposed that a relatively high concentration of potassium was present in this ocean. Evolutionary speculations suggest that the cytoplasm of earIy organisms closely resembled the composition of the primordial sea (120). During long-range ecologlcal changes potassium precipltated out in the form of s1licates on the bottom of the ocean. Finally the sea had a high sodium and low potassium composition. By the formation of cell membranes the living organisms protected themselves agalnst the $r$ 
INTRACELLULAR

100 Prot $^{-}$

$50 \mathrm{CL}^{-}$

(a) $40 \mathrm{Na}^{+}$

$110 K^{t+}$

100 Prot $^{-}$

$80 \mathrm{Cl}^{-}$

(b) $111 \mathrm{Na}^{+}$

$69 \mathrm{~K}^{+}$

\section{EXTRACEILULAR}

$150 \mathrm{Cl}^{-}$

$145 \mathrm{Na}^{*}$

$5 \mathrm{~K}^{+}$

before equilibrium

Gibbs-Donnan equilibrium

$74 \mathrm{Na}^{+}$
$46 \mathrm{~K}^{+}$

$150 \mathrm{Cl}^{-}$

$145 \mathrm{Na}^{+}$

$5 \mathrm{~K}^{+}$ active transport

osmotic equilibrium

Flgure I, 1: Hypothemia, as applied in preservation techniques, will slow down the $N a / K$ pump activity in cell membranes. Since these membranes are impermeable for (negatively charged) proteins, the diffusible lons will distribute themselves in a predictive way. This flgure Bhows a simplificated scheme of this situation, known as the GlbbsDonnan equilitibrtum.

a. Mstribution of lons at the onset of hypothermia before equilibration lis established.

b. Glbbs-Donnan equilibrium across the cell membrane under hypothemle clrcumstances (see text). The excess of lons ins1de the cell membrane induces osmotic imbalance and subsequent cell swelling.

c. For comparison the normothermic situation is 1llustrated here. Fqual osmotic pressure on both sides of the cell membrane is maintained by active transport of sodlum lons out of the cell. 
changed environment. In addition, these membranes had the advantage of malntalining a desirable conflguration of proteins and organic molecules. However, the development of membranes involved the need for active transport mechanisms. By active extrusion of sodium osmotically cell swelling could be prevented. This interaction between intra- and extracellular solutions will be explalned here in more detail.

Cell membranes are impermeable for intracellular organlo acids and proteins. At normal $\mathrm{pH}(7.4)$ these proteins are negatively charged (anlons). Hence, if there are no active transport mechanisms within the cell membranes, the diffusible lons will distribute themselves in a predictable way. A simpliflcated scheme of this situation, known as the "GibbsDonnan" equilibrium (121) is shown in figure $I, \mathbb{1}$.

Before the establishment of the equilibrium, as deplcted In figure $I, 1^{a}$, the chemical concentration gradient for $\mathrm{Cl}^{-}$ will induce a net movement of diffusible anlons ( $\mathrm{Cl}^{-}$) into the cell. By this $\mathrm{Cl}^{-}$Influx the cell w1ll become negative. This potential difference in turn results in a redistribution of cations $\left(\mathrm{Na}^{+}, \mathrm{K}^{+}\right)$. After the establishment of an equilibrium (figure $I, 1^{b}$ ) the potential alfference for aiffusible lons is described by the Nernst equation (122):

$\mathrm{E}_{\mathrm{d}}=\frac{\mathrm{RT}}{z \mathrm{~F}} \ln \frac{\left(\mathrm{C}_{1}^{+}\right)}{\left(\mathrm{C}_{\mathrm{e}}^{+}\right)}=\frac{\mathrm{R} T}{z \mathrm{~F}} \ln \frac{\left(\mathrm{A}_{\mathrm{e}}^{-}\right)}{\left(\mathrm{A}_{1}^{-}\right)}$

* $\mathrm{E}_{\mathrm{d}}=$ electrical potential difference

$\mathrm{R}=$ universal gas constant

$T$ = absolute temperature

$z=$ valency of 1 ion

$F=$ Faraday's constant

$\mathrm{C}_{1}=$ cation Intracellular

$\mathrm{C}_{\mathrm{e}}=$ cation extracellular

$A_{1}=$ anion intraceliular

$A_{e}=$ anion extracellular 
Simpliflcation of this expression gives the following relationship between the difuslble (unlvalent) lons:

$$
\frac{\left(C_{1}^{+}\right)}{\left(C_{e}^{+}\right)}=\frac{\left(A_{e}^{-}\right)}{\left(A_{1}^{-}\right)}
$$

If the amount of mols $\mathrm{Cl}^{-}$which have moved into the cell is called $x$, the ion concentration values in the equilibrium sltuation can be calculated by solving the equation:

$$
\frac{\left(\mathrm{Na}_{1}^{+}\right)+\left(\mathrm{K}_{1}^{+}\right)+\mathrm{x}}{\left(\mathrm{Na}_{e}^{+}\right)+\left(\mathrm{K}_{\mathrm{e}}^{+}\right)-\mathrm{x}}=\frac{\left(\mathrm{Cl}_{\mathrm{e}}^{-}\right)-\mathrm{x}}{\left(\mathrm{Cl}_{1}^{-}\right)+\mathrm{x}}
$$

After substitution of the lon concentration values of figure $I, 1^{a}$ (the numbers are chosen for explanatory purposes):

$$
\frac{150+x}{150-x}=\frac{150-x}{50+x} \quad x=30
$$

So in absence of active transport (Gibbs-Donnan equil1brium), the concentration of $\mathrm{Na}^{+}, \mathrm{K}^{+}$and $\mathrm{Cl}^{-}$in and outside the cell can be calculated.

The $\mathrm{Na}^{+}$and $\mathrm{K}^{+}$concentration ratios are reciprocal to the $\mathrm{Cl}^{-}$concentration ratio.

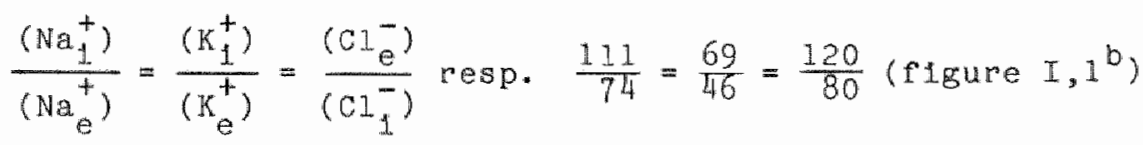

In this equilibrium situation a concentration difference exists for non-diffustble lons (by defintition (121)). Moreover, the total amount of diffustble ions inside the celi is also greater (260 inside versus 240 outside). By this osmot10 gradlent water w11. move into the cell. In the vegetable kingdom the cell can protect itself agalnst these osmotic forces by a rlgld cell-wall of cellulose. However, the animal cell membrane would lose its motility and deformability under this high osmotic pressure. Hence, as lilustrated in 
flgure $I, I^{C}$, there is a need for active transpont meohanisms to prevent cellular swelling. Equal osmotic pressure on both sldes of the cell membrane 1 s malntalned by active extrusion of sodlum lons out of the cell. In mammallan specles this energy dependent $\mathrm{Na} / \mathrm{K}$ pump requires oxygen, substrates and nomothemic conditions for optimal function.

Hypothermia, as applied in preservation technlques, w111 Induce a slowing down of the Na/K pump which results in osmotic cell swelling. Inltially the effectiveness of callins solutions for cold storage of kldneys was attributed to the higly potasslum content of this "intracellular" fluld. However, surrounding the cell with a $K^{+}$rich solution (11ke the primordial ocean) would cause as much osmotio cell swelling due to the Glbbs-Donnan equilibrium (flgure I, $I^{b}$ ). Indeed, as demonstrated later by collins hlmself (50), the beneflcial effect of this solution must be ascibed to the presence of poorly diffusible molecules (glucose) and slowly permeant anions (phosphates).

Previously this was also show very clearly by Acquatella et al. (123). In dog kidneys perfused with a collins solution without glucose $\left(C_{1}\right)$, enomols cellular swelling leading to tubular damage was observed. After 48 hours cold storage with a hypertonic solution contalning $\mathrm{K}_{2} \mathrm{SO}_{4}, \mathrm{NaHCO}_{3}$ and glucose, histological sections showed excellent preservation of renal tissue $\left(\mathrm{SO}_{4}{ }^{2-}\right.$ is a less permeant anion). Downes et al. (124) showed that a hyperosmolar solutlon with high sodlum and low potassium and sucrose was as effective as Collins in 24 hour preservation of dog kianeys. They concluded that during cold storage 1 t was cellular welling and not intraceliular potassium 10ss which primarily caused the poor renal function after implantation. States et al. (125) demonstrated that the $\mathrm{Na} / \mathrm{K}$ pump restored the intracellular potasslum content $1 \mathrm{n}$ kldney slices whlch had been rewarmed and oxygenated after preservation in an extracellular like solution for 48 hours. Later green and Pegg (126) also emphasized the importance of osmoticaly active and Impermeant 
neutral solutes and anlons In wash-out solutions.

These newtral molecules, when counteract osmotic cell swilng, cannot prevent a net movement of difrusible electrolyte into the cell (see figure I, ${ }^{b}$ ). In addition glucose, as appled in colins solutions, will slowly penetrate the cell during prolonged perlods of cold storage (124). Therefore these preservation flulds are made hyperosmolar. However by 1 on shifts across the cell membrane and osmotic imbalance, these hyperosmolar preservation solutions may even Lead to cell shrinkage. Southard et al. (127) developed an 13o-omolar solution that would effectively prevent both cellular swelling and shrinkage during hypothermia. They observed no lncrease in slloes of dog kldneys lncubated in an lso-omotic solution in which the major part of the anions was composed of the large lmpermeant anlon lactoblanate (4- $\beta-D$ galactos 1do-D-gluconle ac1d). Lateron good results were obtalned with an 1so-osmolar perfusate contalning sodiumgluconate, which was effective in preventing hypothermic-1nduced cel1 swell1ng $(128,129)$.

After hypothermic perfusion and revascularisation the osmotic equilibrium across the cell membrane will agaln be fully dependent on actlve transport mechanisms. This $1 \mathrm{mpl}$.es that the mitochondria w111 have to remaln intact to account for the energy requirements of the cell, $1 . e$. adenosine-triphosphate (ATP). Many investigators have emphasized the need Cor adequate preservation of energy generating functions.

Southard et al. (130) studled mitochondrial functions in klaney sllos obtalned from klaneys preserwed up to 48 hours by cold storage. The abll1ty to generate ATP decreased in proportion to the preservation time. Durlng respiration, in absence of ADP and with succinate as substrate, the oxygen consumption observed in sllces from 48 hour stored kidneys was higher than in control slices. This suggests an uncoupIng of oxldation and mitochondrial phosphorylation (ATP synthes1s). Klaneys exposed to warm Ischaemia before hypothermic preservation showed a more rapid decline in mito- 
chondrial function. In another study southard et a1. (131) investigated the effects of hypothermia on the function of isolated mitochondria prepared from fresh dog kidneys. Under hypothermic conditions $\left(5-10^{\circ} \mathrm{C}\right)$ the respiratory rate was suppressed; however, the oxidation remained fully coupled to the phosphorylation. In the presence of the uncoupler dinitrophenol (DNP) the respiration rate did not decrease after lowering the temperature, especially when succlnate was used as substrate. From these data it was concluded that at low temperatures not the respiratory chain is the rate limiting factor, but rather the translocation of adenosine-di-phosphate (ADP) across the mitochondrial membrane (FH. I, 2 ). Impaired rephosphorylation of ADP to ATP will induce conversion of ADP into adenosine-mono-phosphate (AMP) and ATP. So at the cost of ADP the ATP level is masntalned (BIE. $\mathrm{I}, 2)$.

Indeed Buhl and Jörgensen (132) observed relatively normmal ATP-, decreased ADP and increased AMP levels in rabbit kidneys subjeated to several hours of hypothermio ischaemia. During 24 hours hypothermic preservation the amount of AMP decreased while at the same time a progressive accumulation of hypoxanthine and inosine was measured in the renal tissues. This was explained by catabolism of AMP: after deamination of AMP Into IMP (Inosine acld) the nucleotide is hydrolized by 5'-nucleotidase to inosine, which in turn is converted into hypoxanthine by nucleoside-phosphorylase. The cell membrane is permeable to both lnoslne and hypoxanthine, so the catabolism of AMP finaliy leads to a decrease of the sum of adentne nucleotides (SAN). In addition the diffusion of hypoxanthine and Inosine out of the cell means a loss of intracellular precursors for the postischaemic refeneration of nucleotides. Buhl and Jorgensen also demonstrated that the catabolism rate of mono-nucleotides during normothermia was about 50 times higher than during hypothermic cond1tions. So after implantation the ATP synthesis may be impaired due to a low level of adenine nucleotides in the cell, 


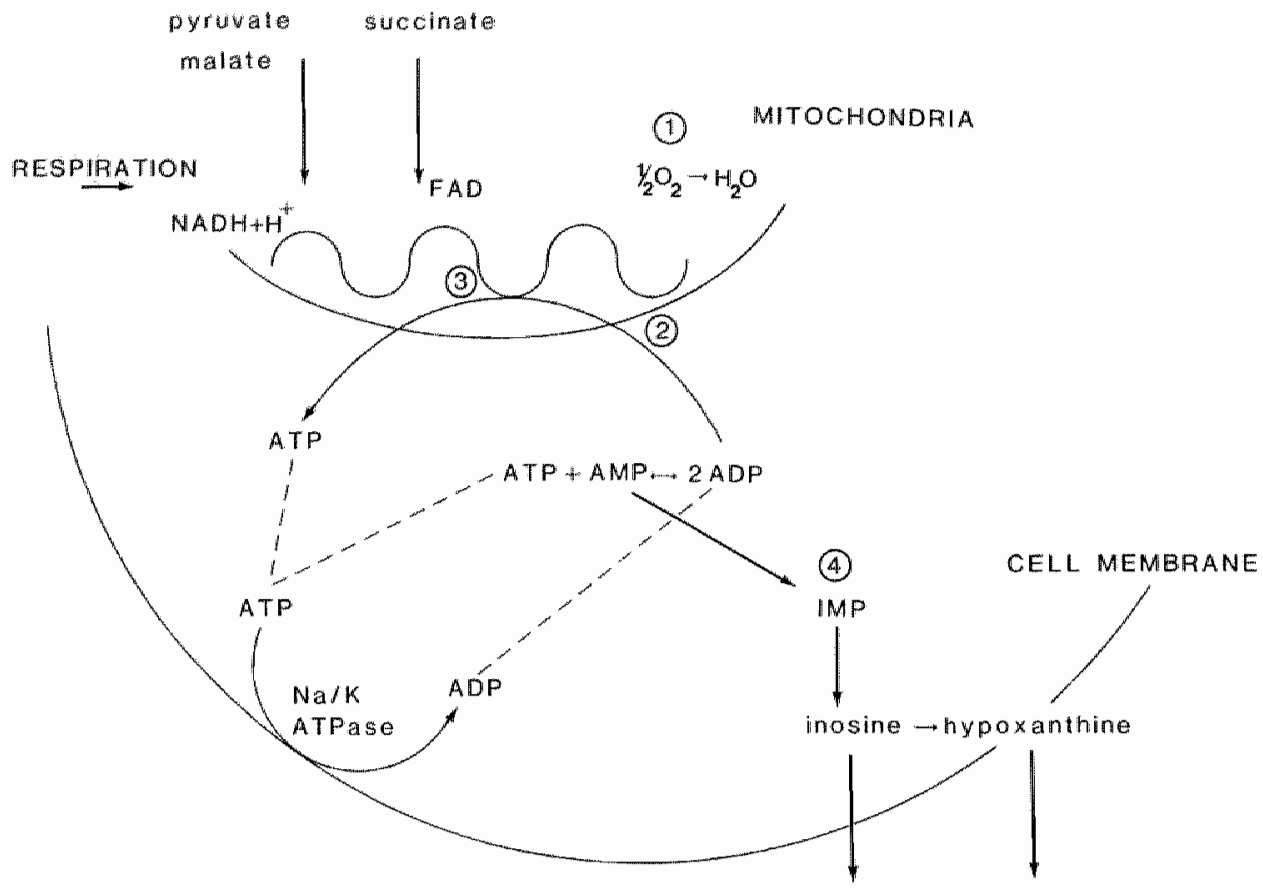

Plgure I,2: Soheme of preservation injury on energy metabo$2 \mathrm{sm}$.

The ATP synthesis may be impalred at several sites:

1. Ischaemia, $\mathrm{O}_{2}$ lack.

2. Suppressed translocation of ADP across mitochondrlal membrane.

3. Uncoupling of oxldative phosphorylation.

4. Catabolism of adenosine-mono-phosphate. (See text) 
even though the mitochondria are intact.

Several investigators $(133,134)$ have suggested that the SAN ralue correlates well with the viablilty of the kloney. Indeed Fischer et al. (135) found hlgher SAN lewels $1 \mathrm{~d}$ dog kidneys stored for 48 hours by "ROP"-preservation than 1 in kidneys preserved by cold storage. In conformation wlth others (136) using this technique, they had previously observed improved renal function compared to slmple cold storage (137). The technlque consists of cold storage with Collins solution $\left(4^{\circ} \mathrm{C}\right)$ comblned with retrograde oxygen persufflation (ROP) through the renal veln: the oxygen diffuses out through the capsular velns whioh are opened by mutiple pricks with a thin needie.

However, in kidneys preamaged by warm 1 schemia the SAN content aid not correlate with viablitty. In these kidneys the better quality of Rop-preservation did not result in recovery of the SAN loss, which had rapldIy occurred during the warm 1schaemia. Apparently the level of Intracellular nucleotides does not reflect the degree of mitochondmic integrity. It is suggested that after prolonged pertods of preservation a slow decrease of adenine nucleotides within the mitochondria may lead to irreversible damage and uncoup$11 \mathrm{ng}$ of oxidative phosphorylation (130).

Bore et al. (138) Indlcated that the abli1ty of mitochondria to produce ATP immediately upon reperfusion was a prerequisity for viablitty. In rat kidneys subjeoted to warm Ischaemia the ATP level measured after ten minutes reperfusion correlated well with subsequent function. Accounting the need for rapld mesynthesis of ATP Belzer et al. (B8) added adenosine ard phosphate to the perfusate during hypothermic perfusion. In human cadaver kidneys they obtalned 80\% Immediate function after preservation of 22 to 58 hours and a mean warm ischaemia time of 24 minutes (range $0-55$ min). Some Investigators have attempted to reduce the catabolism and loss of adenine nucleotides by exogenic gupplement of inosine and adenosine. Fernando et al. (139) demon- 
strated that rat klareys were protected from 60 minutes wam Bcharia by prior lntra-arterial lntusion of 1nosine. Pretreatment with lnosine resulted in a more rapid resynthesis of ATP upon reperfusion. Thls beneficlal effect of lnosime was also round by Buhl et al. (140) In rabblt kidneys, although the lmproved renal function in the inosine treated group was not attended with higher postischaemic ATP levels. on the other hand in cold-stored kidneys the pretreatment with Inosine had unfortunate results because it produced further damage to the kidney. It was sugeested that crystallization of lnosine at hypothemla might be responslble for this fallure.

By addition of ajlopurinol or adenosine to the preservation fiuld, Buhl et al. (141) observed Improved function in rabblt klaneys after 48 hours of cold storage. Allopurinol was found to reduce the loss of intracellular nucleotides by an Inhlbitory effect on 5'-nucleotidase.

From the results of the above mentioned studies it can be concluded that certain steps in the energy metabolism are affected during and after hypothermic ischaemia. Since the reactions in the intracellular metabolic pathways are all ljnked to each other, one cannot regard one of these steps to be critlcal to the viability of the kldney. The data of several Investigators rather suggest a time sequence for metabolide changes to occur (142).

\section{gectlon 5: Preservation at sub-zero temperatures}

Although "cryopreservation" is not the subject of the present study, some remarks about freezing of organs should not be omitted in this thesis. The complete arrest of metabollsm by storage at very low temperatures $\left(e .8 .-196^{\circ} \mathrm{C}\right.$ ) would enable an unlimited preservation time. However, there are some Important drawbacks lnvolved in this seemingly attractive approach to organ banking. The main problems w111 
be mentioned here.

a. Freezing of cells

During freezing of salt solutions the concentration of solutes increases. As lice formation goes on, this plse in salt concentration progressively lowers the freezing point of the remalning solution until the socalled "eutectio temperature" is reached. Below this temperature water solldiples together with the solute elther as a hydrated salt or as crystalline salt and crystaliline water (143). For example, an isotonlc sodium chlorlde solution ( 0.15 molar) reaches a concentration of 5.2 molar (concentration factor: 35 ) at $-21.6^{\circ} \mathrm{C}$ unt11 the last 11quid freezes (143). This lmplies that between the beginning of water-orystallization and eutectic freezing, the concentration of a solute depends only on the temperature. In 1953 Lovelock (144) showed that this Increase in salt concentration is the princlpal cause of Injury which occurs after freezing of cell suspensions. High concentrations of electrolytes would damage the lipoprotelns of cell membranes, which increase the permeabllity to cations (145). As a result the cells become hypertonlc whtch leads to osmotic lysis upon thawing and resuspending in an isotonlic medium.

During subzero-cooling of cell suspensions the formation of lce crystals starts in the extracellular space at -2 to $-5^{\circ} \mathrm{C}$. Intracellular crystalization does not accur at these temperatures. The celi interior would not contalin effective nucleators to form lce crystals above $-10^{\circ} \mathrm{C}$ (146). Slnce the vapour pressure of supercooled water is higher than that of ice at the same temperature, the simultaneous existance of extracellular ice and intraceliular supercooled fluld induces a thermodynamic Imbalance across the cell membrane. This aifference results in a water movement out of the cell, which leads to cell shrinkage and increase in concentration of Intracellular solutes. Hereby the freezing polnt is depressed and the intracelilular formation of lce is prevented. A high cooling rate allows insufficlent time for water to 
leave the cell, and results in intracellular lce fomation, which 1 s usually lethal to the cell. It has been suggested that subcellular organelles are disrupted by lice crystals (147). However, the amount and size of intracellular lee crystals can be reduced by extremely rapid cooling. The survival of such cells depends highly on the rewaming rate. During slow rewarming there is sufflcient time for recrystallization, which has a damaging effect as yet. So the optimal cooling rate of cells should be slow enough to prevent intracellular loe formation and fast enough to avold a severe increase in concentration of electrolytes. Since the cell membranes of various cell types have a different permeabil1ty for water, each cell type has 1 ts optimal cooling rate. However, in most cells it is not possible to prevent the injury by Increase of concentration as well as the damage by lce formation (148).

In presence of cryoprotectants, such as glycerol and dimethyl sulphoxide (DMSO), the Increase in electrolyte concentration can be reduced. For example, a solution contalning 2M glycerol solidifles at $-45.5^{\circ} \mathrm{C}$. The concentration of glycerol at this temperature amounts $8.45 \mathrm{M}$. So during slow cooling the concentration increase of the electrolytes is the same as that of glycerol, 1.d. only 4.23 times. Hence in presence of cryoprotectants optimal freezing of cells can be obtalned at lower cooling rates since both the concentration rises and intracellular lce formation can be avolded.

At the eutectic temperature freezing $1 s$ modifled probably by the strong hydrogen binding capacity of glycerol. The high viscosity of the solution prevents crystal formation, and the liquid tends to solidify in an amorphous state (143).

Low molecular cryoprotectants such as glycerol may have a damaging effect themselves. These substances penetrate the cell at a much lower rate than water, so they may damage the cell by osmotic effects when they are added or removed in hibh concentrations. This implies that in presence of cryo- 
protectants the rewarming of frozen cells should be performed slowly.

By the utilisation of glycerol or DMSO, successful oryopreservation of a number of cells can be achleved. Long term storage of red blood cells (149), lymphocytes (150), bone marrow (151), spermatozoa (152) and manmallan embryos (153) has been performed without unacceptable loss of viabjlity. b. Freezing of organs

Freezing and thawling of whole organs lnwolves speclal problems. First, organs conslst of varlous cell types which may have alfferent optimal cooling rates. Secondly, the cooling rate of bulk organs is limited due to their thermodynamic properties. The low ratio of surface area to volume prevents rapid cooling. So high concentrations of cryoprotecting substances are necessary to obtain a compromise cooling rate for the survival of all different cells.

The addition and removal of cryoprotecting agents require organ perfusion techniques. Jacobsen (154) showed that rabbit kidneys perfused with glycerol in concentrations up to $4 \mathrm{M}$ recovered nomal renal function after autotransplantation. Osmotic damage to the kidneys could be prevented by gradual introduction and wash-out of glycerol using hypertonic perfusates. However, kldneys equ1librated with $3 \mathrm{M}$ glycerol and frozen to $-80^{\circ} \mathrm{C}$ for 30 minutes showed no $\mathrm{sign}$ of function after removal of glycerol and implantation. PegB et al. (155) also reported unsuccessful attempts to preserve rabblt kldneys and hearts by the use of hlgh concentrations of cryoprotectants with slow freezing and thawing. Halasz et al. (156) observed life sustalning function in 25 per cent of dog kidneys protected with glycerol and frozen to $-50^{\circ} \mathrm{C}$ for 15 minutes. Guttmann et al. (157) reported survival of dog kidneys protected with DMSO, frozen by intra arterial hellum to $-80^{\circ} \mathrm{C}$ for 15 minutes and thawed by microwave irradiation. However, these good results could not be repeated by Pegg et a1. (158). 
The mechanlams of freezing Injury in whole organs have been pat lally elueldated. Jacobsen (154) observed cessation of blood flow in autotransplanted rabolt kidneys protected w1th $3 M$ glycerol and frozen to $-80^{\circ} \mathrm{C}$. Histologleal examinaton of the kidreys 30 to 60 minutes after revascularisation revealed glomerular damage and bleeding into the tubulus, suggesting a primary vascular infury. Mhs abservation was supported by the high vascular resistance measured during the deglycerolisation perfusion after freezing. The vascular damage was explatned as follows: after the perfusion with blycerol before freezing the renal caplilaries are widely dilated stnce the collold in the perfusate draws water from the lnterst1tum into the vessels as soon as the perfusion pressure $1 \mathrm{~s}$ removed. So the caplliares are likely to be dispupted by the mechanlcal effect of Intravascular lce during freez1ng. The occurrence of extracollular lce 1 s generally considered as rather innocuous in freezing of diluted cell suspenslons. However, in freezing of organs the pormation of extracellular tee may discupt the morphological structure, since the expansion is prevented by the architecture of the tissues and the high density of interconnected ce11s.

In conclusion the characteristics in which whole organs distingulsh from celi suspensions, namely a fixed geometry, a high density of various cells and a vascular system, are malnly responstble for the disappolnting results sofar obtalned in ireezing of organs (154).

Another appoach to preservation of tissues at low subzero temperature was reported by Fahy and H1rsch (159). In the presence of very ligh concentrations of cryoprotectants golldiflcation wlhout lee formation accurs. This so-called vitrification refers to solidiflcation of a liquid into a non-structured, amorphous state (glass transition) upon coo$11 \mathrm{ng}$ to suflelently low temperatures. In theory this offers an attractive approach to organ preservation. During vitriflcation all mechanlsms whlch cause "freezlng injury", such 
as electrolyte concentration elevation and mechanical damage by Intra- and extracellular lce formation, are avolded. However, the concentrations of cryoprotecting agents required for vitrification are toxic to living organs. Frahy and Hirsch reported that high pressures of 1000 and 2000 atmospheres reduced the cryoprotectant concentration required for vitrification. This discovery of baroprotection provides hope for eventual success in cryopreservation of organs by vitification.

section 6: Combination of different preservation methods

The preservation methods, sofar discussed in this chapter, all have their limitations, advantages and drawbacks. From the two methods currenty used in kidney preservation, the cold storage technique has a maximal preservation time of about 48 hours, whereas the hypothermic continuous perfuslon can be successfully employed up to four days. The exact mechanisms responsible for the limitations in preservation time are not completely understood. There is evidence that changes in the metabolism of parenchymal cells are restrictive to the duration of cold storage (130). According to some authors prolongation of hypothermic continuous perfusion seems to be prevented mainly by progressive endothelial damage 1 nduced by the mechanlcal perfusion 1tself (160). So from theoretical point of vilew the comblnation of the two methods could have a synerglstic effect, making long-term kidney preservation possible. However, as reported by Belzer and Southard (160), attempts at intermittent hypothermic perfusion and cold storage have been disappointing. Kidnays preserved with this procedure were inferlor to kidneys elther cold stored or perfused separately for the same time.

In clinical kidney preservation a comblnation of the two methods is often employed for technical and practical reasons. Mostly hypothermic continuous perfusion af kidneys 
Which have suffered a constaterable warm lschaemia time (see section 3) stapte after several hours of cold storage, because the centre performing the donor-nephrectomy does not have the disposal of a perfusion machine.

To evaluate the effectiveness of this preservation procedure Denham et al. (103) compared the combination of continuous perfusion and cold storage with both techniques separately in an experimental model. Canlne kidneys subjected to 15 minutes of warm ischaemia were preserved for 24 hours by elther hypothermic continuous perfusion, six hours perfusion followed by 18 hours cold storage, six hours cold storage wh subsequent 18 hours perfusion, or cold storage alone. Two hours after autotransplantation renal function was assesied by creatinine clearance deteminations. In these experiments hypothermic continious perfusion was found to be superior to the other techniques. The combination perfuslon - cold storage was slightly better than cold storage followed by perfusion, which was in turn much better than cald storage alone.

Milner and Lakely (161) confirmed that the comblnation of hypotherinc continuous perfusion and collins technique ylelded inferior results compared to hypothermic perfusion alone. Simflar results were obtained by scott et al. (162) and Woods et al. (163). In 24 hour preservation of dog kidneys they combuned hypothermic perfusion with cold storage in the same perfusate (cryopreclpltated plasma). The comblnation of 18 hours hypothermic perfusion followed by six hours cold storage (Scatt et al.) had a remakable bad result: this combination revealed no lire-sustaining kidney function. Summarialng the data of comblned technlques during 24 hour kldney preservation, it can be concluded that the best results were obtalned when kldneys were perfused as long as possible until the time of revascularization. 
A new approach to kidney preservation was introduced by Kootstra et a1. In $1980(164)$. They showed that the results of four days hypothermic continuous perfusion of canine kidneys could be slgntricantly improved by a normothermic penfusion of four hours halfway the preservation period. Durlng the normothemic perfusion, the preserved kldney was connected with the femoral vessels of the again-anaesthetised donor dog. The possiblities of thls so-called "ex-vivo" perfusion were investigated further by Van der Wijk et al. (165).

The combination of four hours normothemic ex-vivo perfusion and $\mathrm{six}$ days hypothermic continuous perfusion revealed life-sustalning kidney function in flve out of six experiments. On the contrary, one out of six dogs survived autotransplantation in the control group with only hypothermic perfusion. In other experiments the slx day hypothermic perfusion was comblned with one, two and three hours intermediate perfusion. In this six day preservation model the best results were obtained with three hours ex-vivo perfusion.

The experiments presented in this thesis are based on the experiences and results obtained by Van der W1jk and Kootstra. The study is a continuation of their previous work. The results of six day experimental kidney preservation will be presented. The comblnation of hypothernlc continuous perfusion with various types of three hour normothemic intermediate perfusion w11l be compared with hypothermic perfuston alone.

In chapter II the experimental model 1 s described. Furthermore detalis are glven about the laboratory animals and the surglcal procedure. In the next chapters four series of preservation experiments are described. The kldney function wis assessed by measurement of blood flow, urine production, glomerular flitration and tubular secretion rate. The serum creatinine concentration values and histologleal data after 
Implantation are presented.

The results of each experlmental group are discussed separately.

In chapter VI the development of a new heart-lung machine, especially adapted for the perfusion of preserved kidneys, $1 \mathrm{~s}$ described. A number of pllot studies with the newly bullt heart-Iung machine $1 \mathrm{~s}$ reported in chapter VII. These experiments were useful for the technical improvenent of the isolated blood perfusion. In chapter VIII a final series of preservation experiments $1 \mathrm{~s}$ described. In this group successful $\$ 1 x$ day kidney preservation was achieved by combined hypothermic and nornothermic perfusion. In chapter IX speclal attention will be pald to the blood flow durling the 1ntermedlate blood perfusion, which played an important role In the ultimate results of the experiments.

Finaliy the possible mechanisms involved in the beneficial effect of the intermediate normothermic perfusion on hypothermic perfusion will be discussed in chapter $X$. 
Laboratory animals: For the kidney preservation experiments mongrel dogs of both sexes were used with a body welght of 20 to $30 \mathrm{~kg}$. The animals had not been used prevlously for other experiments and were apparently healthy. During the experiments the animals were kept in separate cages at room temperature. They were fed on a nomal laboratorial diet and were allowed to drink water at liberty.

Experimental model: In all preservation experiments the kidneys were preserved for $s 1 x$ days (Fig. II, 1). After unllateral nephrectomy the right kidney was immediately flushed through the artery with Eurocolilns solution at $4^{\circ} \mathrm{C}$. Subsequently hypothermic continuous perfusion was performed in a preservation machine (Gambro(B), Lund, Sweden). After six days hypothermic continuous perfusion the preserved kidney was implanted in the donor dog. The auto-transplantation model was selected to avold immunological damage of the preserved kidney. One hour after implantation the contralateral kidney was renoved and the animal was now fully dependent on the preserved kidney.

Anaesthesla: The animals did not recelve food and water during the night before operation. As premedication $0.5 \mathrm{mg}$ atropin 1.m. was given half an hour prior to the operation. Anaesthesia was induced with thiopenthotal (Nesdonal $(\mathrm{B}) 20 \mathrm{mg}$ per $\mathrm{kg}$ body welght $1 . \mathrm{v}$. Immediately thereafter the animal was 1ntubated and anaesthesia was continued by ventilation with a nitrous oxlde/oxygen mixture supplemented with halothane (Fluothane ${ }^{B}$. During the operation the dogs were hydrated by intravenous infusion of $500 \mathrm{ml}$ glucose solution (5 $\mathrm{g} / 100 \mathrm{ml})$ and $500 \mathrm{ml} \mathrm{NaCl}$ solution $(0.9 \mathrm{~g} / 100 \mathrm{ml})$. Through- 


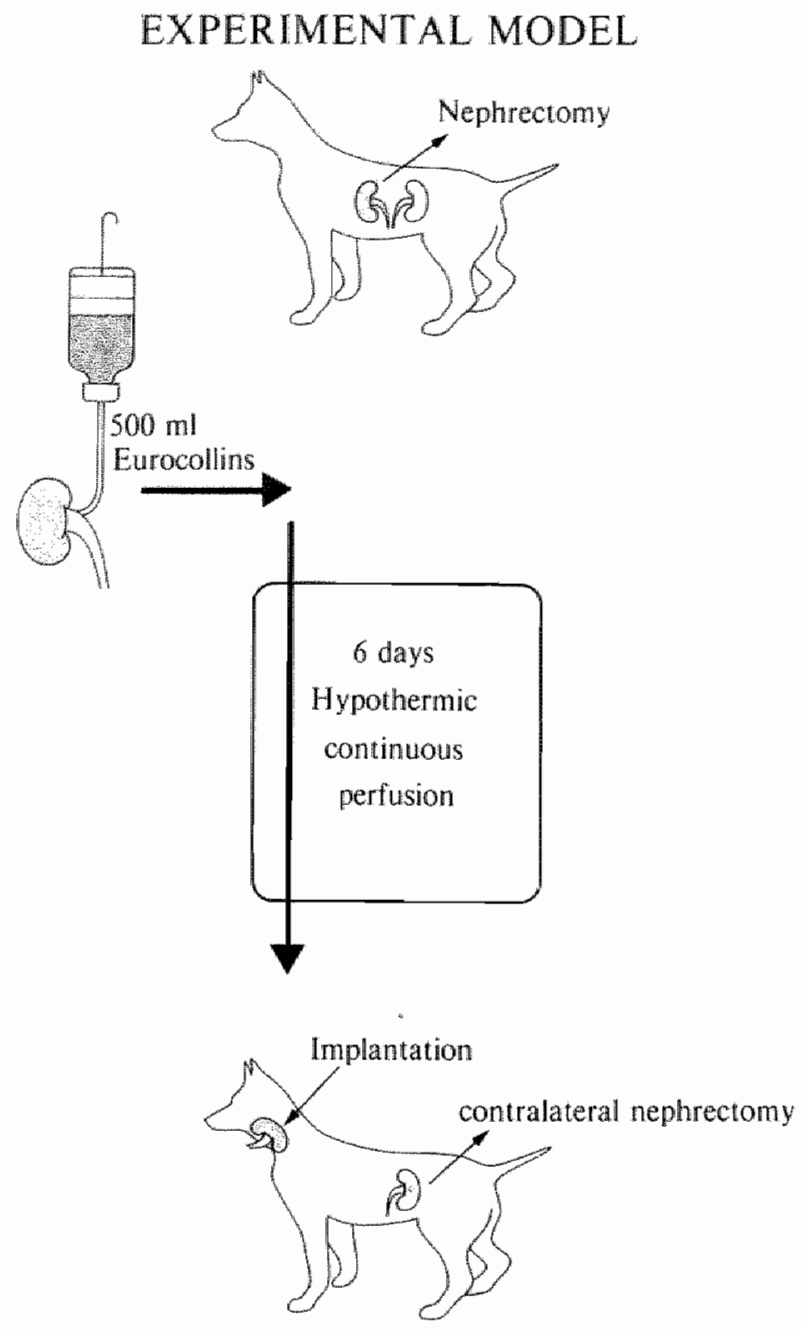

Flgure II, 1: Experimental mode1.

After six days preservation autotransplantation was performed followed by contralateral nephrectomy. 
out cach operation the animals lay on a themostatic waten mattress $\left(37^{\circ} \mathrm{C}\right)$.

Surgical procedure: Nephrectomy: The anaesthetised dog was placed on his left slde on the operating table. The right subcostal region was carefully shaven and the skin was desInfected with an alcohol solution contalndis two per cent lodine. Subsequently the dog was covered with sterlie towels. A subcostal 1ncision was made. The external obllque muscle was transsected. The internal oblique muscle and the tramsversis abdominis muscle were split parallel to thelr Pubres and the abdomen was opened. So the right k1dney was exposed intraperitoneally. The subcostal incision was prePerred above a midline abdominal lmclsion. By a subcostal. Inclston the kidney oan be exposed without handling of $1 \mathrm{n}-$ testinal loops, which might prevent postoperative intussusception to a large extent.

First the fibrous flbres between gerota's fascla and the dlaphragma were dissected. Hereby the upper pole of the kldney was moblised. The perirenal fat was removed. Durdng this procedure small vessels between the perirenal fat and the klaney were ligated as much as posslble. Subsequently the renal artery and vein were dissected free on the dorsal slde of the kidney. The ureter was divided about $10 \mathrm{~cm}$ distally to the kldney and freed upwards to the hilus. A small sll1con tubling $(0.096$ in 0.D., 0.068 in I.D., Down Coming Corp. Midland, M1chlgan) was inserted Into the ureter. Five minutes before clampling of the renal vessels, 100 mi mannltol solution $(20 \mathrm{~g} / 100 \mathrm{ml})$ was glwen $1 \mathrm{ntravenously.} \mathrm{Flrst}$ the renal antery was clamped and dissected and gubsequently the renal vein. Within two minutes the kidney was weighed and a plastic cone-shaped cannula was inserted in the renal. artery. The kldney was flushed with $500 \mathrm{ml}$ Eurocoll1ms golution (Table III, I) at $4^{\circ} \mathrm{C}$ and transferred to the Gambro preservation machine. The renal wessels $1 n$ the donor dob were ligated with slik and abdomen was closed in two layers 


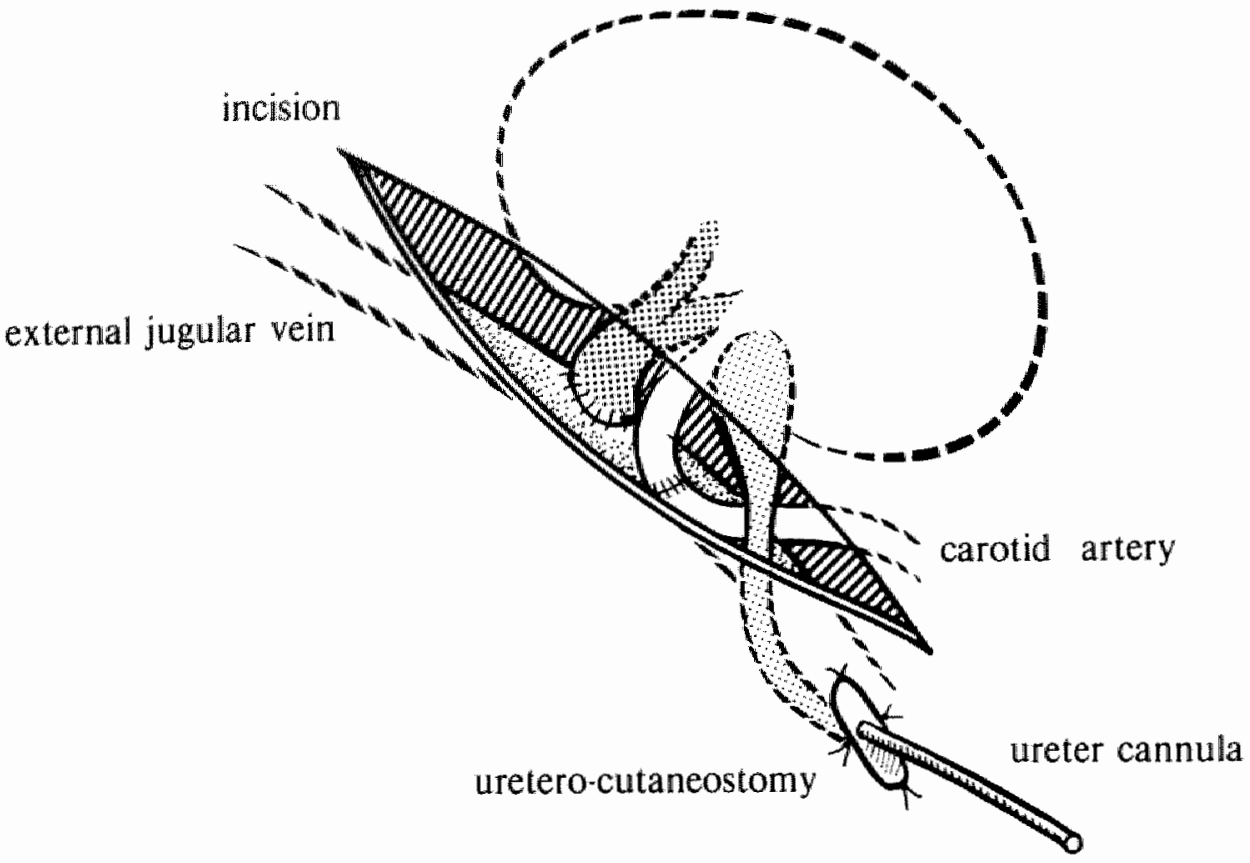

Pleure II,2: Implantation of the preserved klaney was perfomed at the left slde of the neck. The menal vein was anastomosed end to slde to the external jugular veln, the renal artery end to end to the carotid artery. The kidney was placed in a subcutaneous pocket and a uretero-cutaneotomy was made. 
with chromic catgut. The skin was closed with interrupted mersliene sutures.

Implantation: After slx days the donor dog was angesthetised as mentioned before. The animal was placed on 1 ts right slde on the operating table. The left flank and left collar region were carefully shaven and desinfected. The remalning parts of the dog were covered with sterile towels. First a subcostal incision was made and the left kldney was dissected free according the same technique as applied for the right kldney. The kidney was left in situ, only attached by its vessels, and a cannula was inserted in the ureter to collect the urine. Subsequently implantation of the preserved kidney was performed. A longltudinal incision was made on the lateral side of the neck. The external jugular vein was dissected free the length of about $5 \mathrm{~cm}$. By separation of the musculus sternocephalicus and the long muscles of the neck the common carotid artery was exposed. The renal vein was anastomosed end to side to the external jugular veln and the renal artery end to end to the carotid artery. The time for performing the anastomoses (6-0 silk, Ethicon) was about 25 minutes. The kidney was placed in a subcutaneous pocket and a uretero-cutaneostomy was made (Fig. II, 2). The silastic cannula was left in the ureter and flxed with one suture to the skin near the uretero-cutaneostomy. All anjmals received antiblotic prophylaxis (amoxiciline, $1 \mathrm{~g} / \mathrm{day}$ ) during the first five days after implantation. Besides technical raclilty, the implantation of the kidney in the animal's neck has several advantages:

First, the risk of intusseption is avolded which 1.s a frequent complication after abdominal operations in dogs.

Secondly, the diuresis can be observed continuously and clearance studies can be performed after implantation. However, the technique is not sultable for long-term postoperative follow-up as in immunological experiments since the kidney is likely to be damaged by ascending infectlons after 
a rew weens

\section{Statiot 10 :}

A non-parametric method was used for statistical analysis of the results. The Wleoxon test was chosen for comparing the results of the alfferent groups. 
In this chapter the results of six day kldney preservation are presented. In elght dogs the kldneys were preserved by hypothermic continuous perfusion. The semes (group I) served as control group for the other preservation experiments described in the next chapters.

Materials and methods:

According to the experimental model described earlier, the right kidney was removed under general anaesthesia. The renal artery was cannulated and the kidney was fushed with Eurocollins solution $\left(4^{\circ} \mathrm{C}\right)$. The compostition of this collins solution is given in Table III, 1 . Subsequently the kidney was transferred to a preservation machine (Gambro ${ }^{\circledR}$, Lund, Sweden). The kidney was placed in the organ chamber of a disposable sterile preservation cassette, which was connected with the Gambro machine (FIg. III, I and III,2). As perfusate $800 \mathrm{ml}$ albumin solution (Kabl Vitrum, Amsterdam, The Netherlands) was used. The composition of the perfusate is given in Table III, 1. The temperature of the perfusate was kept between 5 and $7^{\circ} \mathrm{C}$. The systolic perfusate pressure was indicated by a pressure manometer and the perfusate flow could be estimated by calibration of the pump speed.

Pure flltered oxygen ( $200 \mathrm{ml}$ per minute) was blown into the organ chamber above the surface of the perfusate. During the flist minutes of the hypothernic perfusion the perfusion pressure was adjusted to $60 \mathrm{~mm} \mathrm{Hg}$. After one hour perfusion the perfusion pressure was readjusted to $20 \mathrm{~mm} \mathrm{Hg}$.

Dally pH measurements of the perfusate were made at $37^{\circ} \mathrm{C}$ (ABL, Blood gas analysator, Radlometer, Copenhagen, Denmark).

After the six day preservation period the kidney was autotransplanted. One hour after recirculation of the pre- 

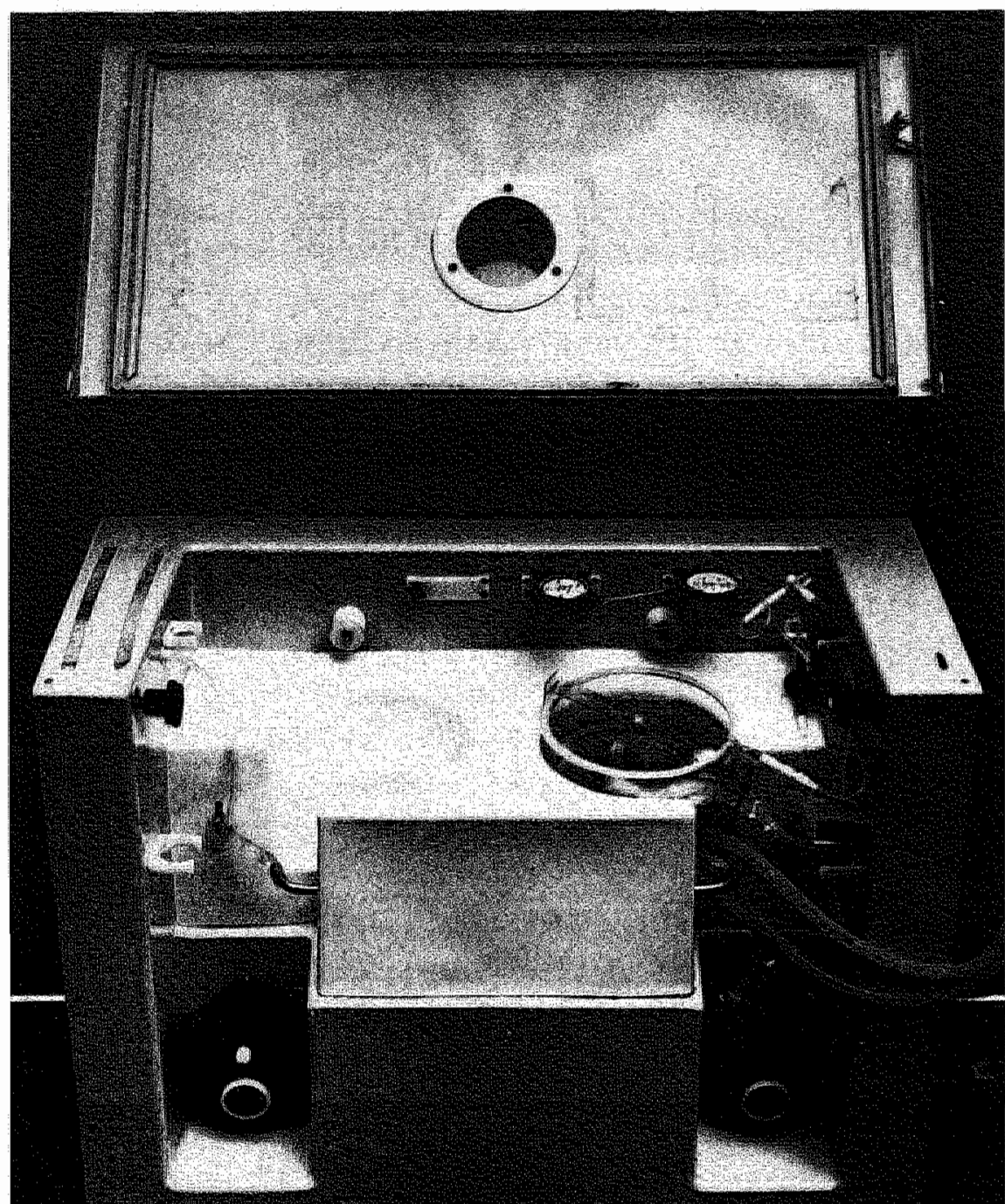

P1eure IIT, 1: Gambro preservation machlne used for hypothermic continuous perfusion of kidneys. In this apparatus the kidneys were perfused for six days with an albumin perfusate (see F1g. III, 2). 


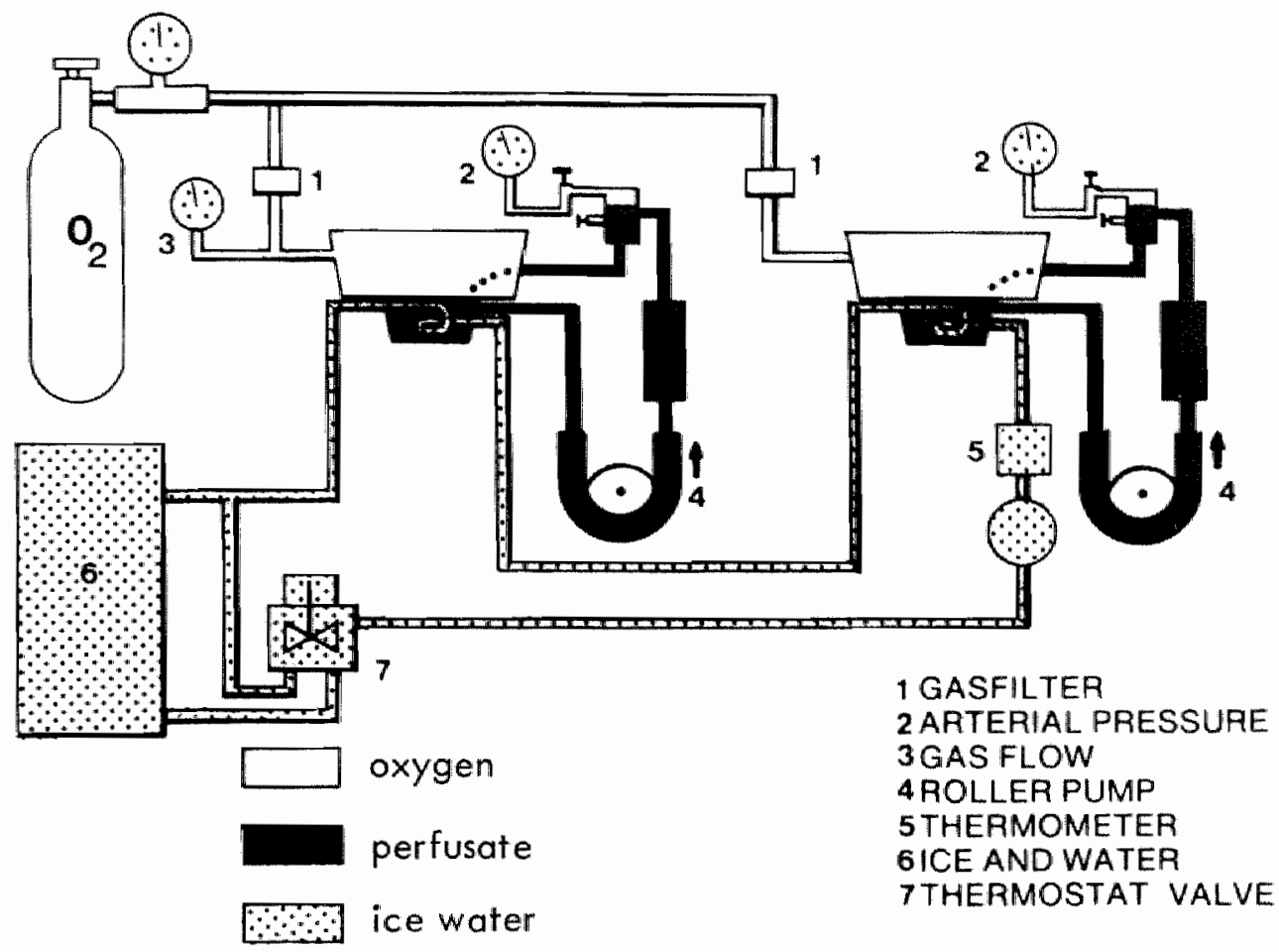
Figure III, 2: Scheme of Cambro preservation machine applied for hypothermic continuous perfusion of kidneys. Two disposable perfusion circults can be placed in this apparatus (see Fig. III, 2). 
Table III, $:$ COMPOSITION PER LTTER OF THE EUROCOLLINS SOLUTION USED FOR FLUSHING THE KLDNEYS AND OF THE PERFUSATE USED IN THE GAMBRO MACHINE

EUROCOLLINS

\begin{tabular}{|c|c|c|c|c|c|}
\hline $\mathrm{Na}^{+}$ & 10 & mmol. & $\mathrm{Na}^{+}$ & 107 & mol \\
\hline$K^{+}$ & 115 & mmol & $\mathrm{K}^{+}$ & 5 & moll \\
\hline $\mathrm{Cl}^{-}$ & 15 & manol & $\mathrm{Mg}^{2+}$ & 6 & mol \\
\hline $\mathrm{HCO}_{3}^{-}$ & 10 & tnmol & $\mathrm{Cl}^{-}$ & 100 & mol \\
\hline $\mathrm{H}_{2} \mathrm{PO}_{4}^{-}$ & 15 & mmo ]. & $\mathrm{HCO}_{3}^{-}$ & 12 & mmol \\
\hline $\mathrm{HPO}_{4}^{2-m}$ & 42.5 & mmol & $\mathrm{SO}_{4}^{2-}$ & 6 & mmol \\
\hline \multirow[t]{2}{*}{ glucose } & 132 & mmo1 & glucose & 34.24 & mmol \\
\hline & & & albumine & $5 \%$ & $g / V$ \\
\hline osmolad1ty & 355 & $\mathrm{mosm} / \mathrm{KgH} \mathrm{H}_{2} \mathrm{O}$ & osmolallty & 300 & $\mathrm{mosm} / \mathrm{kgH}_{2} \mathrm{O}$ \\
\hline
\end{tabular}

osmolality 355 mosm $/ \mathrm{KgH}_{2} \mathrm{O}$ osmolality $300 \quad \mathrm{mosm} / \mathrm{kgH}_{2} \mathrm{O}$

\section{PERFUSATE}


served kidney, the contralateral kidney was amoved and 100 mi mannitol solution (20 g/100 ml) was glven intravenously. Kidney function after implantation was assessed by dally serum creatinine measurements for two weeks. clearance studies were performed at one hour after implantation. "The glomerular f11tration rate (GR) and the effectve renal plasma Now (ERPF), the latter as tubular parameter were determned by clearance calculations of respectively 125 Iothalamate and 131 -hippurate (166). One hou after Implantation a 3 inGie Injection of $0.010 \mathrm{mCI} 125$ Iothalamate and $0.005131 \mathrm{mcl}$ 131 I-hippurate (Amersham, Buckinghamshire, England) was given Intravenously and the clearances of these labelled compounds was measured during half an hour after ten minutes equilibration. All samples were counted in a dual channel. ganma counter (Hewlett Packard). The clearances of ${ }^{125}$ Iothalamate and ${ }^{131}$ I-hippurate were calculated using the standard fomula $\frac{[\mathrm{H}] \mathrm{V}}{[\mathrm{P}]}=\mathrm{C} \mathrm{ml} / \mathrm{min}$ (167). By dividlng the GRR by the ERPF the flltration fraction (FF) was calculated.

H1stology: At autopsy the lmplanted kidneys were b1sected for gross macroscoplc examination. Wedge-shaped blopsies were flxed in formaline. Light microscopy of these blopsles was performed on $4 \mu \mathrm{m}$ sections stalned with hematoxilln and eosin. Tubular damage was correlated to the assessed amount of" casts; these casts are supposed to be necrotic remants of tubular cells whlch have been passed lnto the tubudar lumen.

\section{Results:}

Hypothermic perfusion: At the start of each pertusion the systotio perfusion pressure was adjusted to $60 \mathrm{~mm} \mathrm{Hg}$. Among the eight experiments the perfusate plow varled from 70 to $80 \mathrm{ml} / \mathrm{min} / 100 \mathrm{~g}$ kidney welght at that perfusion pressure. During the first hour of hypothermic perfuslon the pressure 
HYPOTHERMIC PERFUSION

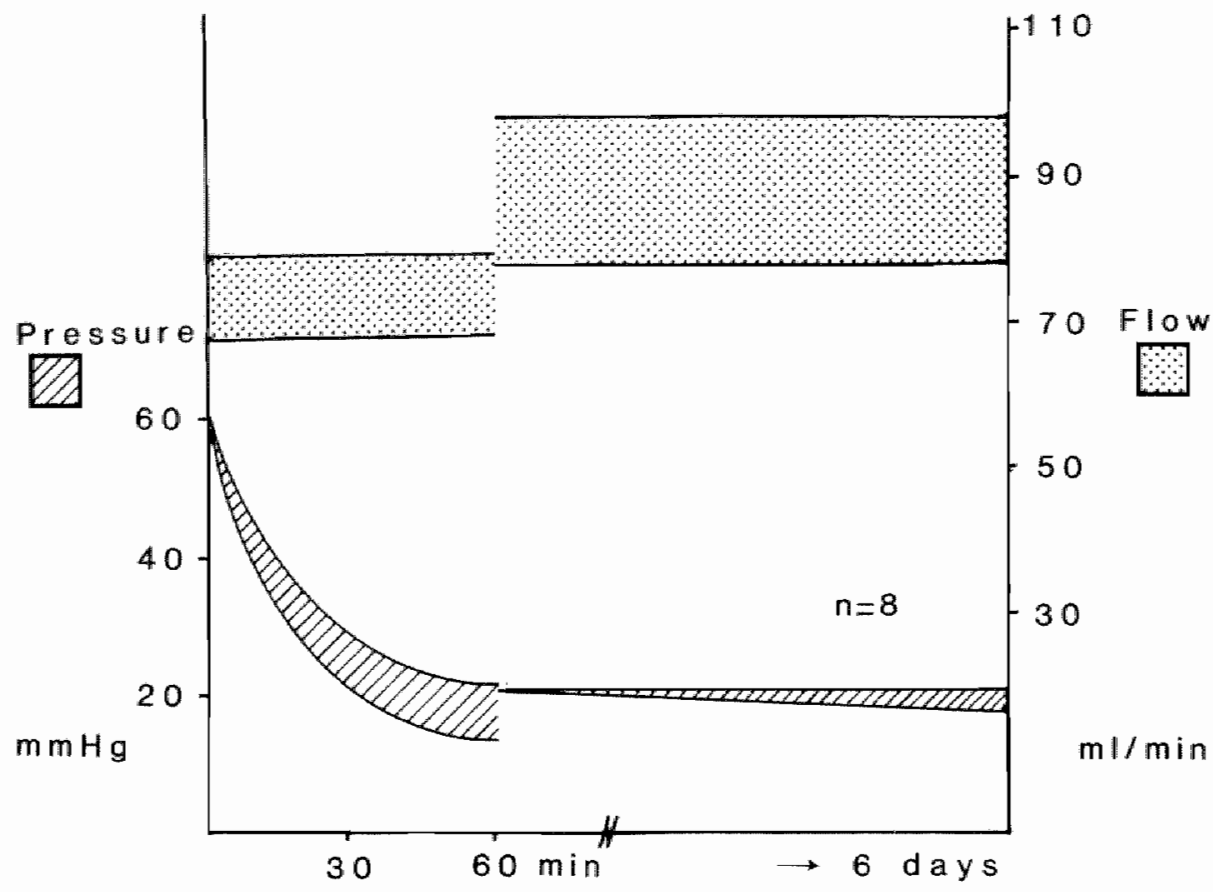

F1gure III, 3: Perfusate pressure and flow during 6 day hypothermlc perfusion of canine kidneys. At the start of the perfusion the pressure was set at $60 \mathrm{mmHg}$. After 60 minutes the perfuston pressure was readjusted at $20 \mathrm{mmHg}$. 
fell to about $20 \mathrm{~mm} \mathrm{Hg}$ or even lower. The perfusate flow amounted 80 to $100 \mathrm{ml} / \mathrm{min} / 100 \mathrm{~g}$ kidney welght at this perfusion pressure (F18. III, 3$)$.

So in all experiments the renal vascular resistance (quotient of mean perfusion pressure and mean perfusate flow) decreased to one third - one fourth of the lnithl va1ue. In all experiments the pH of the perisuse lncreased from 7.0 to about 7.2 (measured at $37^{\circ} \mathrm{C}$ ).

Survival after implantation: Upon revascularisation all k1dneys regalned nomal colour. However, the duresis remained low or anuria occurred. The mean urine production measured at one hour after implantation was $2 \mathrm{~m} 1 / \mathrm{h} / 100 \mathrm{~g}$ (range 0.5 - $3.5 \mathrm{ml}$. On1y one out of elght dogs survived after autoImplantation of the preserved kidney and contralateral nephrectomy. The others died uraemic within flve days after implantation. The only survivor had a maximum serum creatinine concentration of $1030 \mu \mathrm{mol} / 1$ on day five after lmplantation $(\mathrm{F} 1 \mathrm{~g}$. III, 4$)$.

Kidney function after implantation: Al1 kidneys regalned normal colour upon revascularisation. However, as mentioned before, the urine production remalned low (range $0.5-3.5$ Inl, measured one hour after implantation).

Clearances of 125 Iothalamate (GFR) and 131 I-hippurate (ERPF - tubular secretion) rewealed low values at one hour after Implantation (Table III,2). In seven dogs without 11fe-sustain1ng kidney function, the ERPF was equal or slightly higher than the GFR, resulting in a high filtration fraction (FF = GFR/ERPF). In the only surwivor a low FP (0.17) was measured (F1g. III, 5).

H1stology: The dog with 11 fe-sustalning kldney function was sacriflced three weeks after implantation. At autopsy the kldney showed nomal morphology. Howewer, 11 ght-microscoplc examination of biopsies showed $1 \mathrm{gns}$ of pyelonefritis, due 


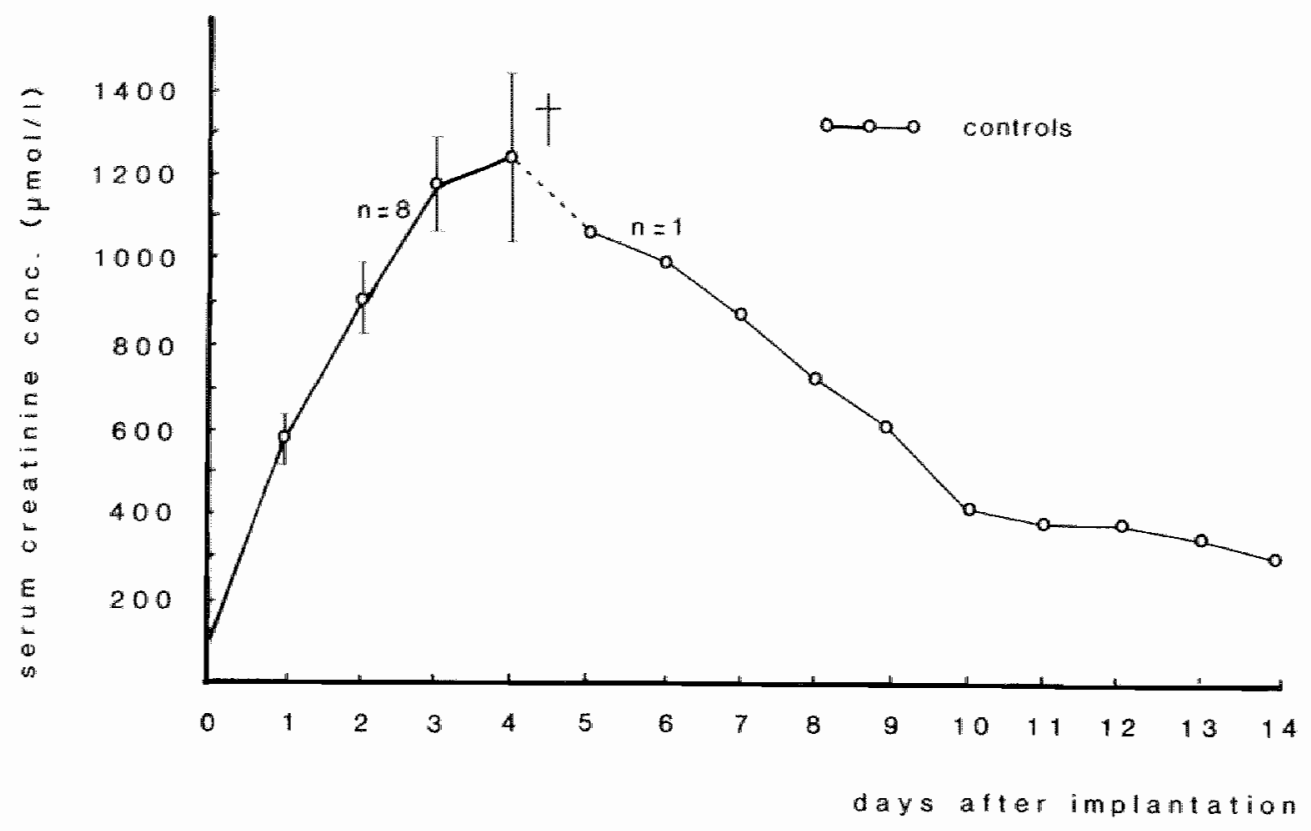

Flgure III, 4: Serum creatinine concentration after six days hypothermlc perfuston (mean values \pm S.D.). Only one out of elght dogs survived after implantation. 
Table III,2: GLOMERULAR FILTRATION RATE, EFFECTIVE RENAL PLASMA FLOW AND FILTRATION FRACTION MEASURED IN SIX DAYS PRESERVED KIDNEYS ONE HOUR AFTER IMPLANTATION

\section{GROUP I (controls)}

\begin{tabular}{|c|c|c|c|}
\hline $\operatorname{dog}$ & $G F R^{a}$ & ERPF ${ }^{\mathrm{a}}$ & $\mathrm{FF}$ \\
\hline 1 & 0.11 & 0.11 & 1 \\
\hline 2 & 0.11 & 0.01 & 1 \\
\hline $3^{b}$ & 0.04 & 0.24 & 0.17 \\
\hline 4 & 0.17 & 0.21 & 0.81 \\
\hline 5 & 0.09 & 0.17 & 0.53 \\
\hline 6 & 0.09 & 0.11 & 0.82 \\
\hline 7 & 0.03 & 0.04 & 0.75 \\
\hline 8 & 0.12 & 0.15 & 0.80 \\
\hline
\end{tabular}

a GFR and ERPF values were calculated $1 \mathrm{n} \mathrm{ml} / \mathrm{min} / 100 \mathrm{~g} k 1 \mathrm{dney}$ welght.

b only survivor* 


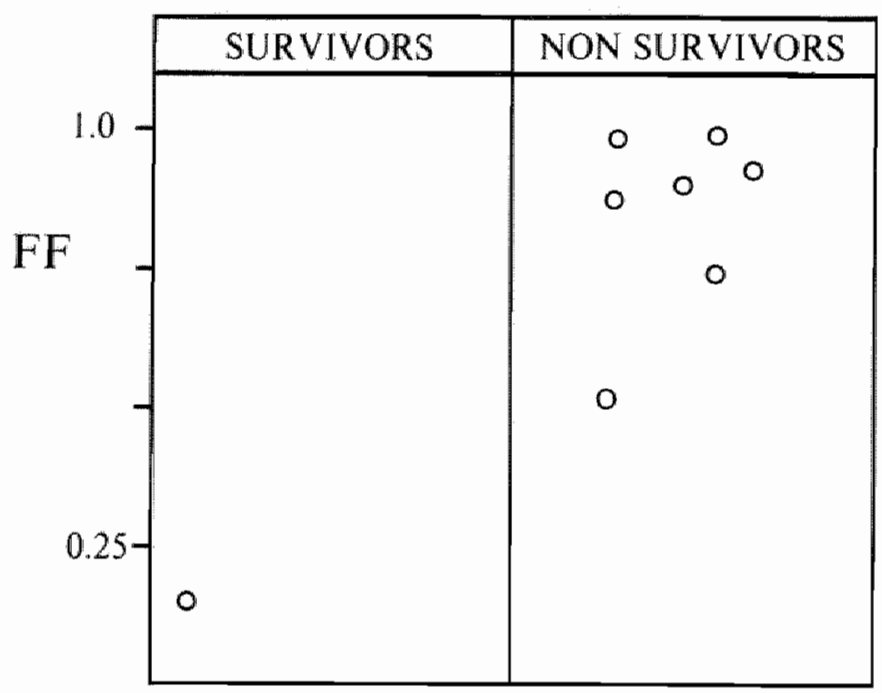

Igure III, 5: One hour after Implantation of 6 days hypothermic-preserved kidneys, high f1ltration fractions were measured in all non-wable kidneys. 
to ascending Infection, which is inherent to the implantation in the neck (168).

In the other non-viabie kidneys severe tubular damase attended. with many casts was observed. Dispersed tubular regeneration was seen. The glomerull and vessels had a normal aspect (FIg. III, 6).

\section{Discussion:}

Successful experimental kidney preservation of three to four days by hypothermic continuous perfusion has been achieved by several investigators $(72,73)$ (Chapter I, 4). However, consistent good results have not been reported after longer preservation periods $(75,69)$. Similar results were obtalned with the "standard" hypothermic preservation technique as described in this chapter.

In earlier experiments by van der W1jk et al., successful four day canine kloney preservation was achleved with hypothermic perfusion in a Gambro-machine and an albumin perfusate (165). Attempts to preserve kldneys for longer than four days falled. The results in this group (I) clearly show that a six day hypothermic perfusion is not ilkely to maintain the viability of the kidney. Only one out of elght dogs survived with a high serum creatinine concentration af ter implantation.

At the start of the hypothermic perfusion in all experiments the perfusion pressure dropped from $60 \mathrm{~mm} \mathrm{Hg}$ to about $20 \mathrm{~mm} \mathrm{Hg}$ within half an hour, whlle the perfusate flow remalned constant. This 1 intial hlgh vascular resistance is probably due to the high potassium concentration of the Eurocollins flush solution. Scott et al. (169) demonstrated that potassium infusion in concentrations exceeding 0.69 $\mathrm{mmol} / \mathrm{min}$ caused vasoconstriction by a direct action on the vessel walls. By flushing with Eurocollins solutions in 


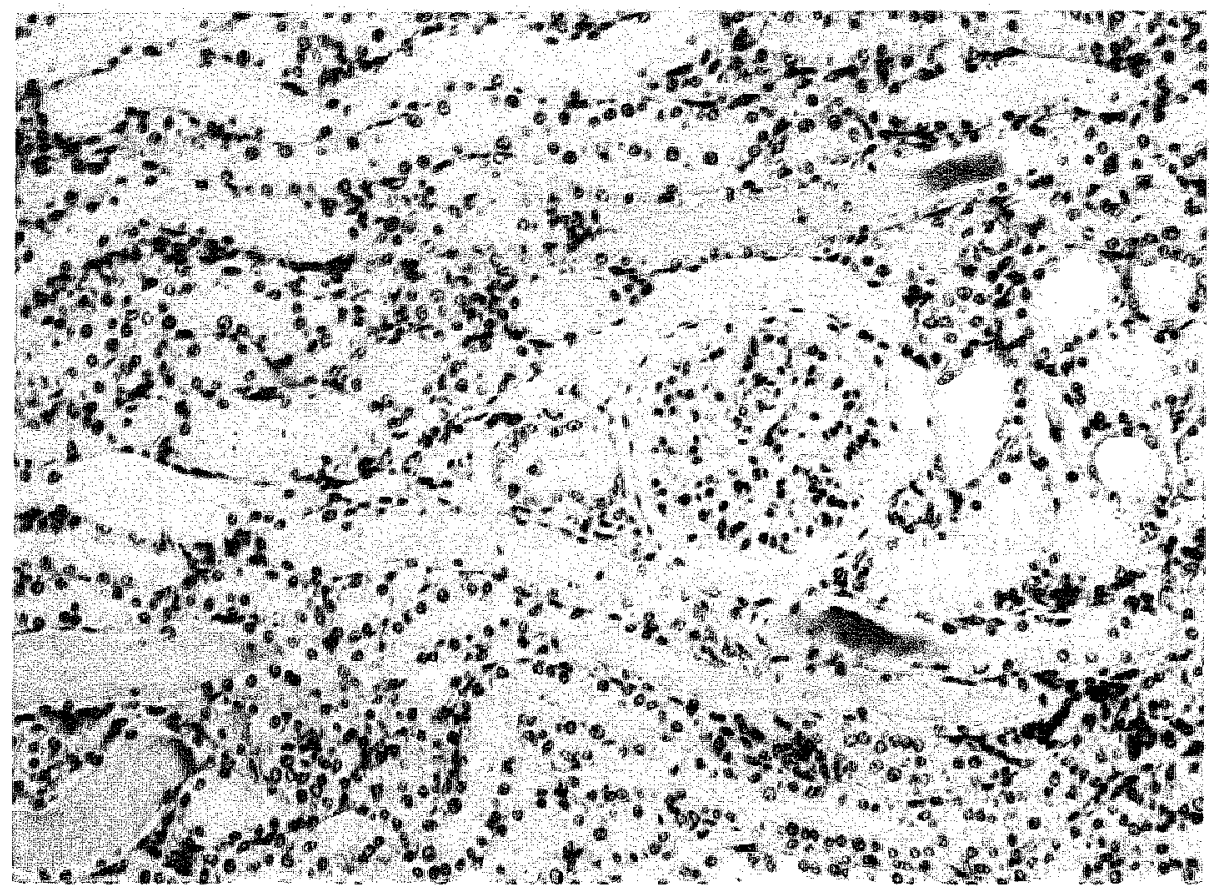

Figure III, 6: After 6 days hypothermic preservation the nonviable kidneys showed severe tubular damage with many casts. The glomerull and vessels had a normal aspect (Hematoxil1in/Eosin, ca. $250 \mathrm{x}$ ). 
tery in concentrations of approximately 6 to 10 mol/minl

During the hypothemic continuous perfusion the pH of the perfusate increased from 7.0 to about 7.2 (measured at $37^{\circ} \mathrm{C}$ ). This phenomenon has 21 so been described by Johnson et a1. (75). The changes in $\mathrm{pH}$ were due to a decrease in carbon dioxide concentration, since no carbon dioxide was added to the oxygen which was blown into the organ chamber.

In all experiments of this group hyperosmolar mannitol was given after surgical mantpulation Just before nephrectomy and after revascularisation at the end of the preservation perlod. Mannitol was supposed to improve the renal blood flow by reducing swelling of tissues and endothellal cells, and thereby restoring clrculation to 1 schaemic areas $(170,171)$.

In all experiments the preserved kldneys were subjected to clearance studies al; one hour after 1mplantation. The $a b-$ solute values of $G F R$ and ERPF did not correlate with the serum creatinine concentration after implantation but their quotient, the filtration fraction $(F F)$, had a predictive value regarding the viablitty of the kidney. In the surviving $\operatorname{dog}$ a low FF was measured, Indicating the presence of active functioning tublules. In the seven non-viable klaneys absence of tubular function resulted in a high flitration fraction.

Histological examination of the non-viable kidneys at autopsy showed severe tubular damage. However, the blaod vessels and glomeruli were intact. Slgns of endothellal damage leading to intravascular coagulation and flbrin thrombi in the glomerular caplilarles were not observed. This socalled "perfusion nephropathy" following hypothermic cont1nuous perfusion has been described by several authors ( 97 , 98) (chapter I,3). It has been suggested that perfusion nephropathy can be prevented by low perfusion pressure in hypothermic perfusion (100) as applied in all preservation experiments described here. 


\section{EXPERIMENTAL MODEL}

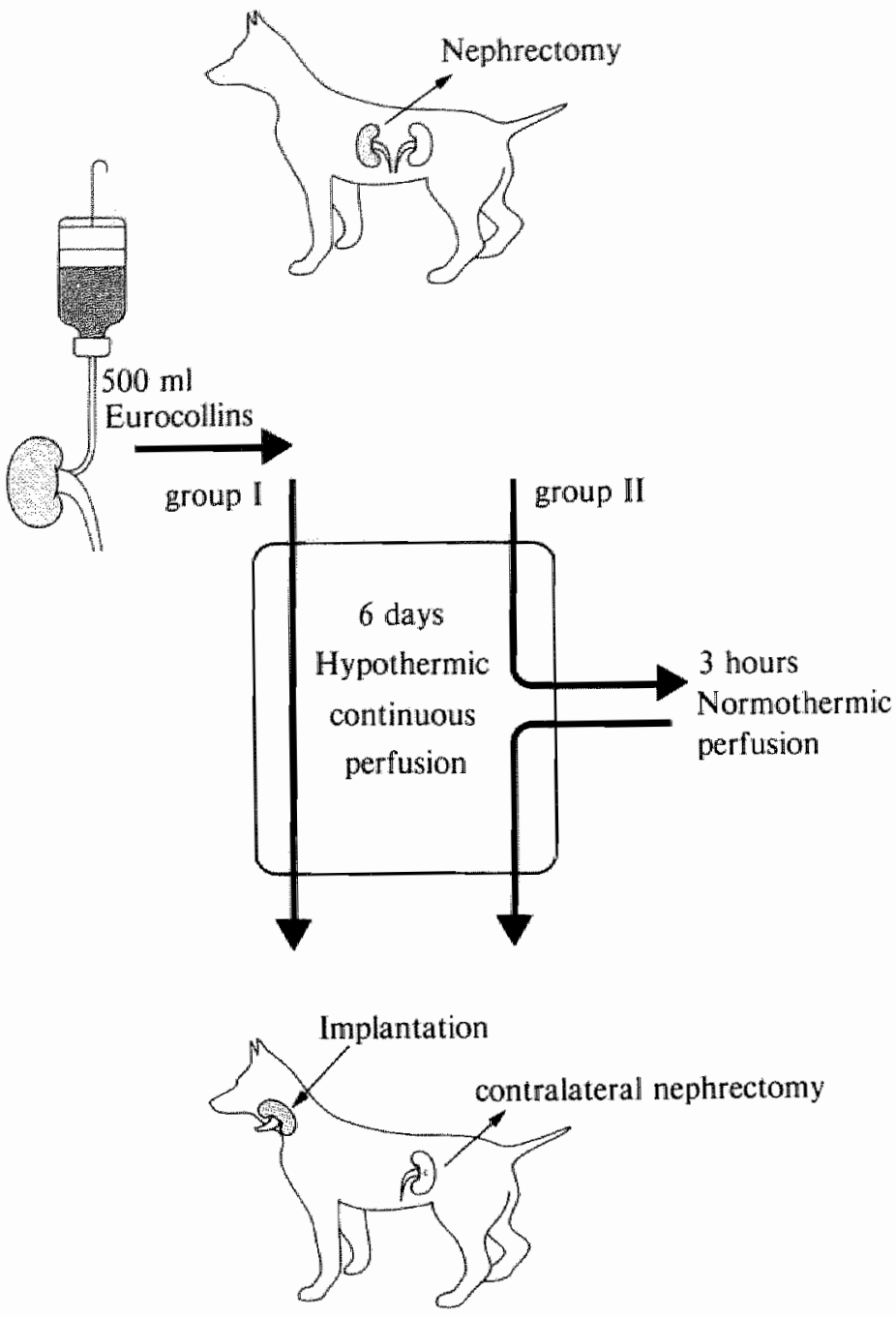

Flgure IV, l: Modifled experimental model. In a series of 7 experiments (group II) kidneys were preserved by hypothermic perfuslon as in group I (controls). Halfway the preservation perlod, kldneys were normothermic perfused for 3 hours. The klaneys were connected ex-vivo with the same donor dogs (Fig. IV, 2). 
The results, described in chapter III, clearly show that successful six day kidney preservation cannot be achleved by hypothermic perfusion only.

A new approach to kidney preservation was introduced by Kootstra and van der Wijk $(164,165)$. They showed that the results of four and six day hypothermic continuous perfusion could be signiflcantiy improved by a few hours normothermic perfusion. During this perfusion the preserved kidney was connected "ex-v1vo" wth the femoral vessels of the agalnanaesthetised donor dog. In the six day preservation model the best results were obtained with three hours ex-v1vo perfusion. The experiments described in this chapter are based on the results of wan der WIjk and Kootstra. In a serles of seven experiments six day hypothermic perfusion was combined with three hours ex vivo perfusion. The beneflclal effect of the normothermic ex vivo perfusion was assessed by determination of GFR and ERPF during the ex-v1vo perfusion.

Materials and methods:

In a serles of seven experlments kidneys were preserved for six days by the same method as described in chapter III. However, halfway the preservation period the experimental model was changed (FIg. IV,1). On the third day the hypothermic perfusion was interrupted and the preserved kidney was connected "ex-vivo" with the same donor dog for three hours. For this ex-vivo perfusion a speclal circult was constructed (F1g. IV,2,3). Under general anaesthesla a femoral artery and vein were cannulated. Before the cannulation heparine, $300 \mathrm{IU} / \mathrm{kg}$ body welght was given intravenously followed by $100 \mathrm{IU} / \mathrm{kg}$ per hour during the ex-v1vo perfusion. The cannulae In the femoral vessels were connected with sllastic tu- 


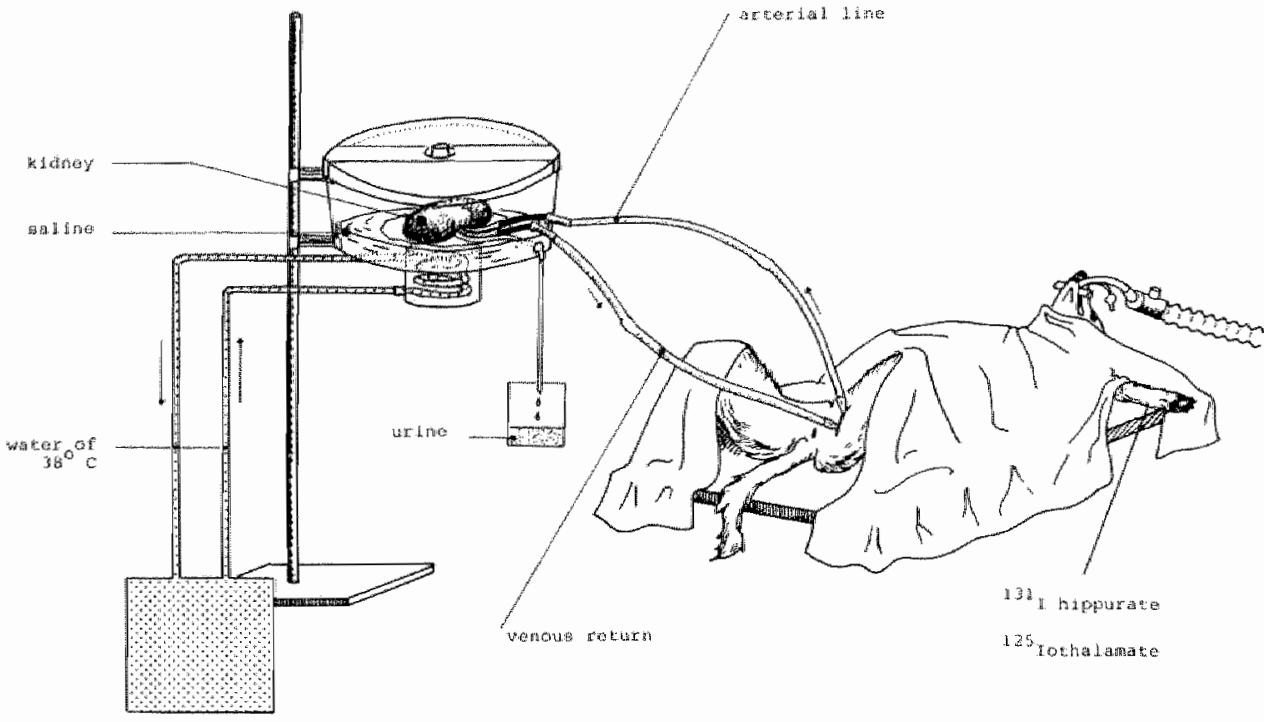

Blgure IV,2: Scheme of "ex-vivo" perfuston in group II. Halfway the $s i x$ day preservation perlod, the kidneys were connected with sliastlo tubing to the femoral vessels of the donor dog. After three hours blood perfusion, the kidneys were placed back on the Gambro machine (see F1g. IV, 2). 


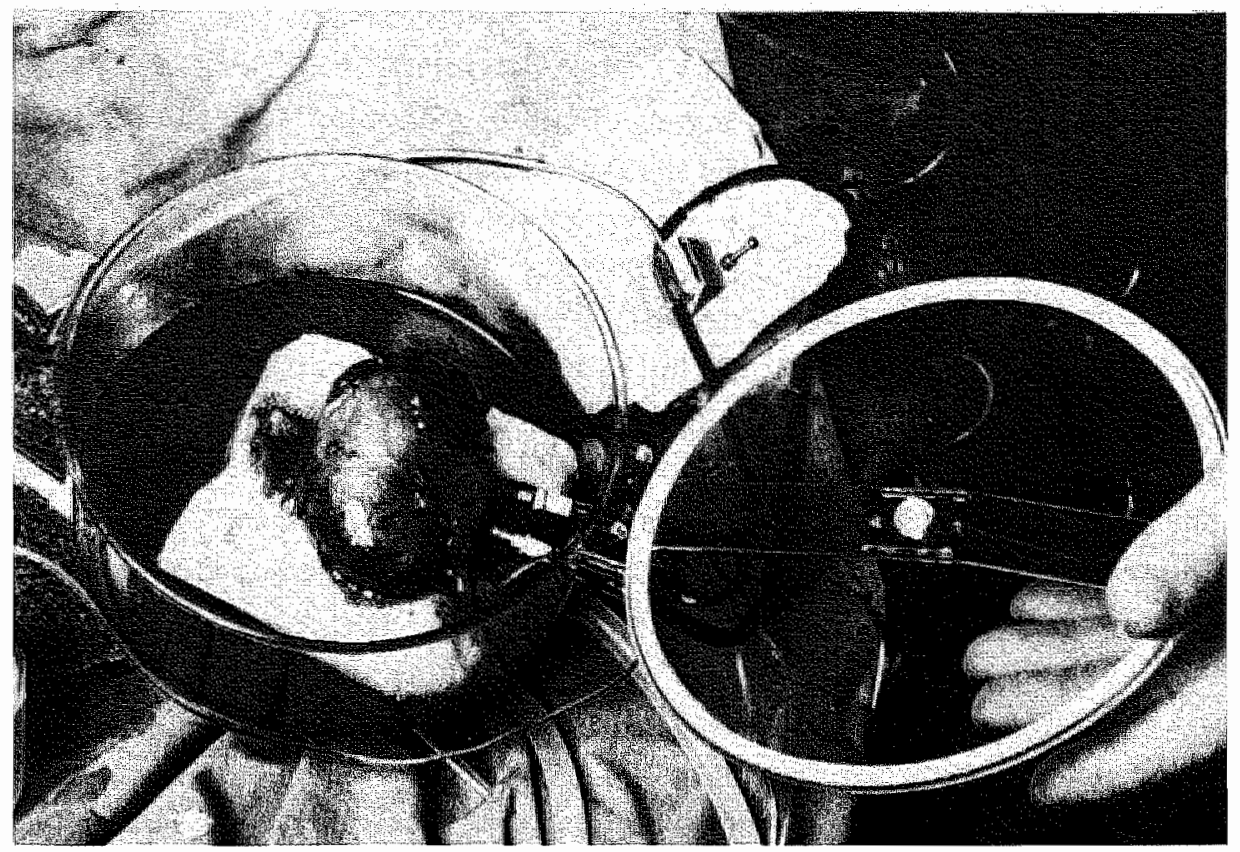

Flgure IV, 3: Ex-Wivo perfusion in group II. To malntain humidity and temperature, the kidney was placed in a disposable organ chamber filled with $500 \mathrm{ml}$ sallme and heated with water of $38^{\circ} \mathrm{C}$ through the origlnal cooling system of the organ chamber (see FIg. IV,2). 
bing to the cannulae in the artery and vein of the preserved kldney. To malntain humidty and temperature the kidney was placed in a disposable organ chamber (Gambro ${ }^{\text {B }}$, fllled wt th $500 \mathrm{~m} 1$ saline solution and heated with water of $38^{\circ} \mathrm{C}$ through the cooling system of the organ chamber. The cannulated ureter was led out through a separate hole in the organ chamber. The arterial and venous blood pressure were measured and recorded on a Sanborn 7700 serles recorder (Hewlett Packard). The venous pressure was kept between 0 and $5 \mathrm{~mm} \mathrm{Hg}$ by varylng the helght of the organ chamber. The blood flow through the kidney was measured in the arterlal line and recorded continuously (Directional Doppler Model 806, Parks Electronles Laboratory). After the ex-vivo perfusion the klaney was flushed with $500 \mathrm{ml}$ Eurocollins solution $4^{\circ} \mathrm{C}$ and the kidney was placed back on the Gambro machine for another three days. The same perfusion pressures were used during the second period of hypothermic perfusion. After the ex vivo perfusion pratamine chloride was given intravenously to the donor dog to counteract the effect of heparine unt11 the clotting time (measured with Hemochron 1200) reached a normal value.

After six days auta-implantation of the preserved kidneys was performed, followed by contralateral nephrectomy. As in the control group mannltol was given at one hour after implantation. Kldney function was assessed by dally serum creatinine measurements for two weeks. One hour after implantation GFR and ERPF were determined as in the control group (Chapter III).

During the normothermic perfusion on the third day of the preservation period, GFR and ERPF were also detemined by clearance calculations of respectively ${ }^{125}$ Iothalamate and ${ }^{131}$ I-hippurate. During this ex v1vo perfusion a loading dose of $0.012 \mathrm{mC1}{ }^{125}$ Iothalamate and $0.005 \mathrm{mC1} 131$ I-h1ppurate was given intravenously. Thereafter a saline solution with 0.040 mal ${ }^{125}$ Iothalamate and $0.050 \mathrm{mcl}{ }^{131} \mathrm{I}$-hippurate was infused In an anticubltal veln of the donor dog. The speed of the 
Infusion pump was $9 \mathrm{ml}$ hour. Urine and blood samples were taken at hourly intervals.

\section{Results:}

Hypothermic perfus1on: During the hypothermic perfusion the same values for perfusion pressure, perusate flow and pH were measured as in the control group (I) (FI. III,I). After the normothermic ex-vivo perfusion, the same perfusion parameters were measured as during the first part of the hypothermic perfusion.

Survival after implantation: Upon revascularisation all k1dneys regalned nomal colour and produced lmmediately urine. At one hour after implantation the unime production was signiflcantly higher (p<0.01; W11coxon test) than in the control group and had a mean value of $53 \mathrm{ml} / \mathrm{h} / 100 \mathrm{~g}$ (range $10-$ $100 \mathrm{ml}$ ). In this group all seven dogs surviwed in a heal thy condition. After implantation the mean serum creatinine concentration reached a maximum value of 580 , mol/1 "range $425-$ $824 \mu \operatorname{mol} / 1)$ on day two and returned to normal values within two weeks $(F \perp B . I V, 4)$.

Kidney function after implantation: "The GFR and ERPF values measured at one hour after Implantation were higher than din the control group (Table IV,1). In the ex-v1vo perfused group much variation was found among these values and the 1nd 1 dual values did not correlate w1th the level of serum creatinine concentration after implantation. As shown in f1Eure IV, 5 in all kidneys low flitration fractions (FF=aFR/ ERPF) were measured at one hour after Implantation (ror comparlson the FF values of the control group are also given). 


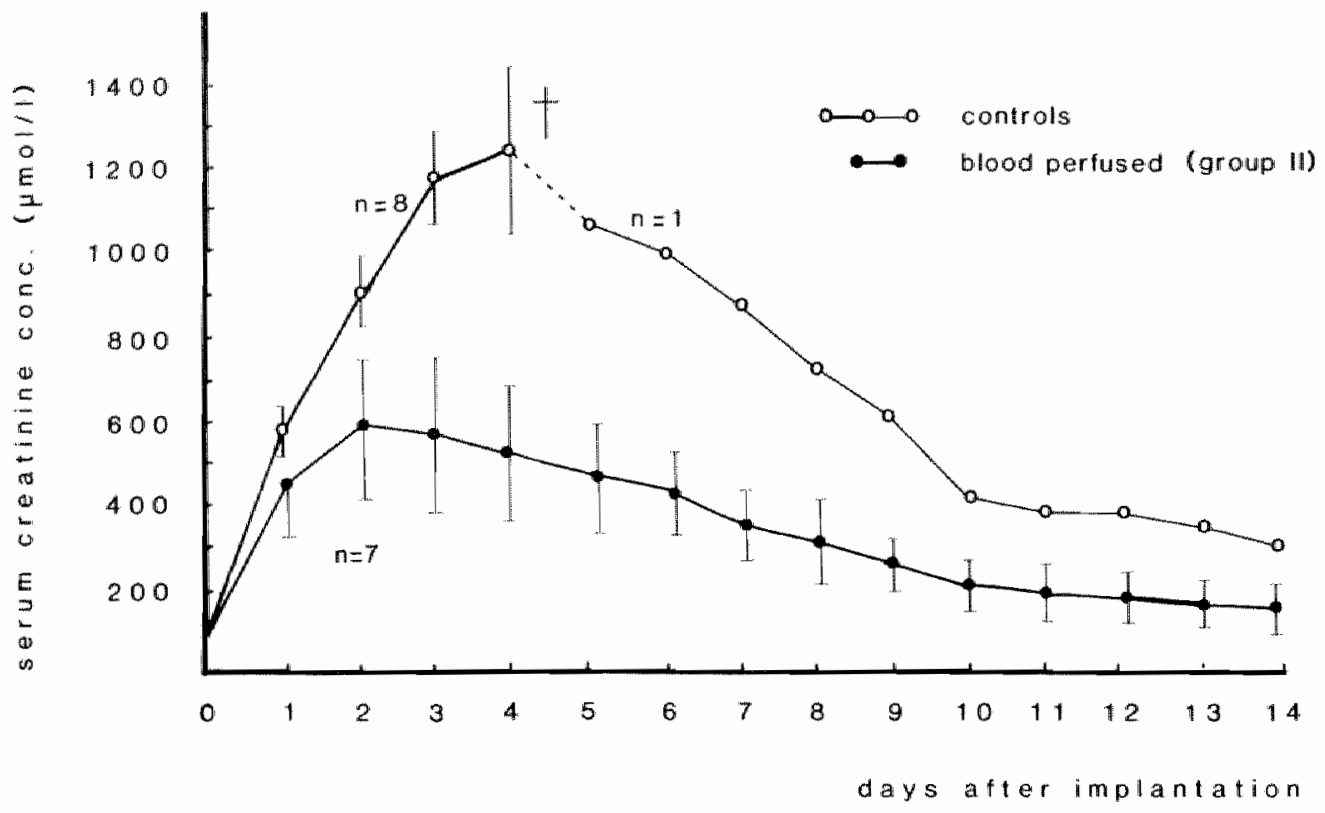

Figure IV, 4: Serumereatinine concentration in group II (mean values \pm S.D.). In the ex-v1vo perfused group all kidneys had iffe-sustalning function after 6 days preservation. The results of the control group (I) with hypothemic perfusion only are also presented. 
Table IV,I: GLOMERULAR FILTRATION RATE, EFEOTIVE RENAL PLASMA FLOW AND FILTRATION FRACTION MEASURED IN SIX DAYS PRESERVED KTDNEYS ONE HOUK AFPER IMPLANTATION

\section{GROUP II (ex-VIto perfused)}

\begin{tabular}{|c|c|c|c|}
\hline dog & $\mathrm{GFR}^{\mathrm{a}}$ & $\operatorname{ERPF}{ }^{2}$ & Fi \\
\hline 1. & 0.41 & 4.24 & 0.10 \\
\hline 2 & 6.26 & 45.93 & 0.14 \\
\hline 3 & 6.78 & 59.35 & 0.11 \\
\hline 4 & 0.8 & 11.154 & 0.07 \\
\hline 5 & 2.94 & 13.40 & 0.22 \\
\hline 6 & 12.57 & 47.77 & 0.26 \\
\hline 7 & 4.52 & 27.85 & 0.16 \\
\hline
\end{tabular}

a GFR and ERPF values were calculated $1 \mathrm{n} \mathrm{m} / \mathrm{m} / \mathrm{m} / 100 \mathrm{kldney}$ weight. 


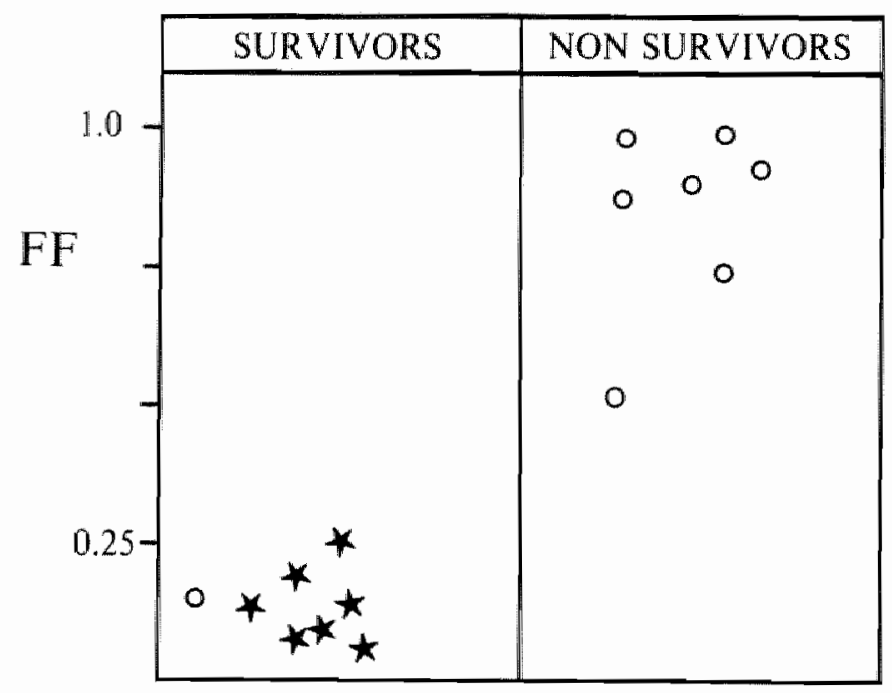

Flgure IV, 5: In group II (ex-vivo perfused) all kidneys had low flutration fractions (FF) at one hour after implantation (*). For comparison the FF values of the control group are aliso given $(0)$. 
Histology: In this group all dogs were sacrifloed three weeks after Implantation. Blopsies of these klaneys showed nomal morphology. However, slgns of pyelonephritis were present to a certain amount in all kidneys due to ascending Infection, whiloh is inherent to the Implantation in the neck $(168)$.

Normothermic ex-vivo perfusion: On the third preservation day the kldneys were connected ex-vivo to the alroulation of the anaesthetised donor dog. All kidneys regalned thelr normal colour as soon as the three hour nomothermio blood perfusion started. Within flve minutes the kidneys produced urine. During the ex-vito perfusion the mean arterlal pressure delivered by the donor dog was between 90 and 100 mm $\mathrm{Hg}$. The mean blood flow through the kidney amounted to $110 \pm$ $17 \mathrm{ml} / \mathrm{m} 1 \mathrm{n} / 100 \mathrm{~g} \mathrm{kidney}$ welght and remalned constant during each separate perfusion. In six out of seven experiments GPR and ERPF determinations were performed during the three hours ex-vivo perfusion (1n one case the urine collection falled). In five out of $s i x$ measurements the GFR and ERPF Increased to a multiple of the first hour values during the perfusion $(\mathrm{Fg}$. IV, 6). In one case the first how values of GFR and ERPF were relatively hlgh; the ERPF showed a moderate decrease in the third hour whereas no change in GFR was observed. In this perfusion the urine production decreased In contrast to the other experiments, In which the low d1uresis rema1ned unchanged throughout the ex-v1vo perfusion. During each perfusion a low flltration fraction $(<0.28)$ was measured.

\section{Discussion:}

In this series experiments (group II) the preservation time of dog kldneys could be extended successful. Iy up to slx days by three hour ex-v1vo perfusion halfway the hypothermid pre- 


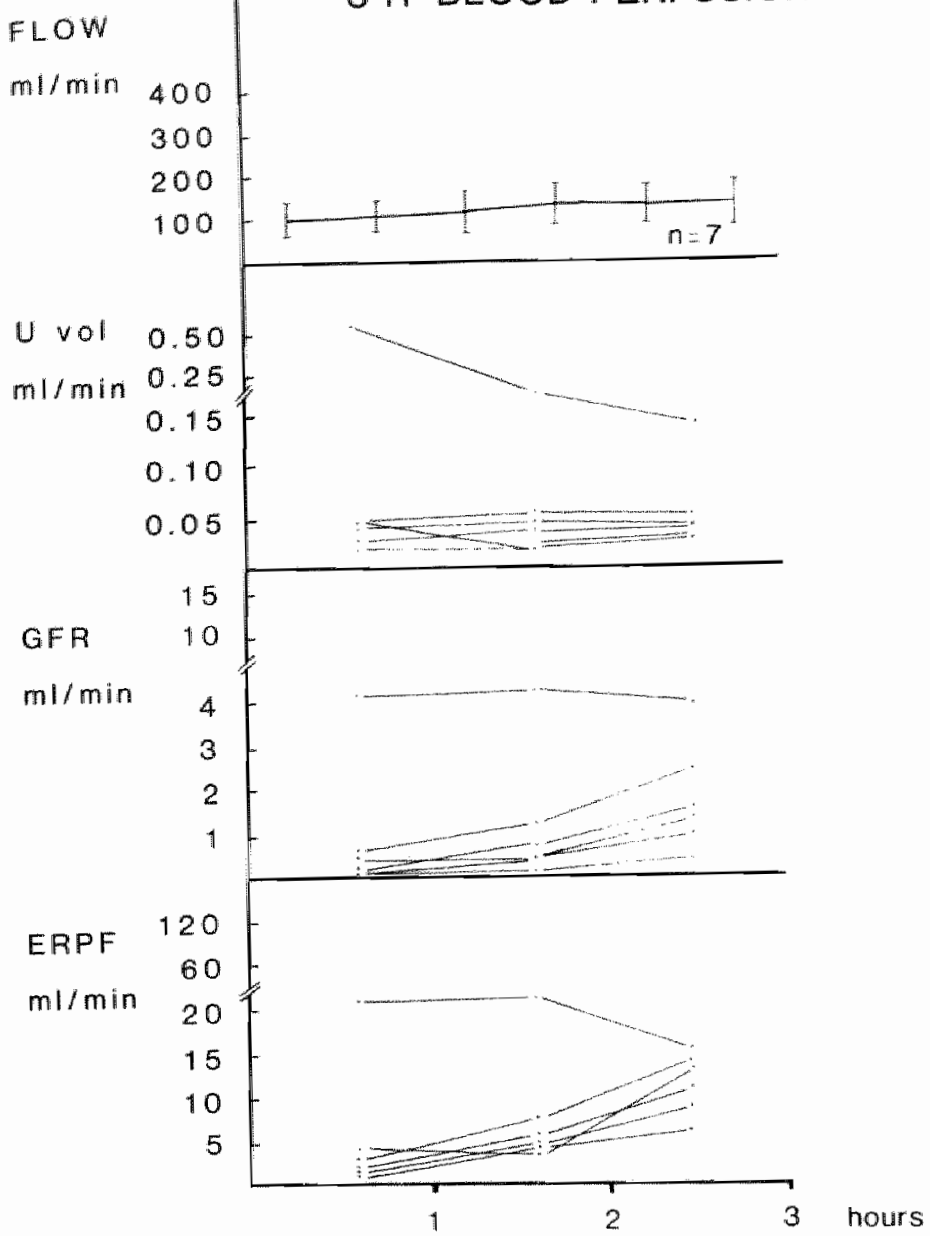

Figure IV,6: Perfusion parameters of the ex-vivo perfusion halrway the six day preservation perlod in group II. The renal blood flow is presented in mean values $\pm S . D$. In six out of seven experiments GFR and ERPF determinations were performed during the three hours perfusion (1n one experiment the urline collection falled). The urlne production, GFr and ERPF are presented for each perfusion. The filtration fraction (GFR/ERPF) showed no vartation and was low throughout each perfusion $(<0.28)$. FF values are not presented in the fligure. 
servation period. In a consecutive serles sever out of seven dogs survived In a healthy condition after implantation $(172)$.

A nomothermic ex-vivo perfusion of kidneys as applied In group II has been used by Baltz (173) and Lavender (174) in the sixties for preservation and viability tests. Laverder demonstrated that it was technical feasible to preserve a kidney ex-vivo ror long time. In a 35 year old male patient wlth terminal renal fallure, a kidney was anastomosed to the vessels 1 the forearm. The renal artery was cannulated, the renal vein dralned freely 1 nto an organ contalner and hence into the vein of the forearm. The venous reservol comprised the entire organ contalner with the kldney. A blood pump was not included in the clmoult. Urine was collected through a cannula in the ureter. Good renal function was measured unt11 rejection occurred after 25 days. Lateron Capter et al. (175) have described an ex-v1vo perfusion model for rabblt k1dneys to evaluate hypothermic storage with new flush solutions.

Nornothermic ex-vivo perfusion in comblnation with hypothermic continuous perfusion has been described by Paugescu et a1. (176). They found that dog heats perfused hypothermically for 24 hours and thereafter functionally tested exvivo fior slx to seven hours could be subjected again to hypothermic preserwation and subsequent ex-vivo perfusion for another period, without loss of viablity and function. In their studies the alm of the ex-vivo perfuston was to evaluate an amino-acid contalning perfusion fluld, whloh was used as perusate in hypotheric heart preservation.

The results of six day kidney preservation in group II are $\mathrm{In}$ accordance with the data of Pauģescu et al. However, the good results are $11 k e 1 y$ aue to a beneflcial effect of the normothermic ex-vivo perfusion itself and not to the special composition of the perfusate in the hypothermic preservation, as stated by Paugescu. The 1schaemic damage to the klaney induced by hypothermic perfusion was restored by 
the nomothermit ex-vivo periusion, which allowed the organ to sustaln another three days of hypothermic preservation.

It must be notloed that the compasition of the perfusate In the Gambro (B) Eurocolins prior to the hypothermic perfusion. Against the successul preservation model the objection can be ratsed that in Group II, the composition of the perfusate was influenced twice by the wash-out with Eurocolilns solution, whereas this occurred only once in the control group. However, 1t 1 s not ilkely that a single Eurocolilns perfusion haleway the preservation period should account for the excellent pesults obtalned in group $I T$. Belzer and Southard (160) reported disappointing results in experiments with cold storage and lntermittent perfusion. In each experiment kidneys treated w1th thls procedure did noticeable worse than kidneys elther cold stored or perfused separately for the same preservation period.

The concept of the ex-vivo perfusion in combination with hypothermic continuous perfusion was established by Kootstra (164) and van der W1.Jk (165), who obta1ned good results in four and six day preservation exper1ments. The alm of the experiments $1 \mathrm{n}$ group II was to study the kldney function during the ex-vivo perfusion of three hours, whlch was the optimal time to 1 mprove the s1x day preservation results (177). In all ex-vivo perfustons in group II low blood flow values were meared whlch was 11 kely due to the low arterlal perfuslon pressure dellvered by the donor dog. First the arterial pessure was reduced by the helght of the organ chamber, whlch was necessary to keep the venous pressure between 0 and $5 \mathrm{~mm} \mathrm{Hg}$. Secondly, the perfusion pressure was lowered by the narrow cannulae flxed in the wall of the organ chamber.

In comparison to the total renal blood flow, very low values for afR were measured during the ex-v1vo perfusion. These low values might be explalned by interstitial oedema, artsen durlng the preceding hypothermic perfuston. The ERPF 
values were four to 20 times higher than the GFR values, which indicate that a concentration gradient of ${ }^{131}$ I-hippurate could be created between the tubular lumen and the peritubular cap1liarles by active functioning tubular cells. During the ex-vivo perfusion a marked increase in GFR and ERPF was observed in five out of $51 x$ cases, total blood flow being constant. The increase in ERPF was greater than the rise in GFR. This finding may indicate an improving extraction of ${ }^{131}$ I-rippurate, a phenomenon also described in human renal allotransplantation during the first 24 hours (178). As opposed to the increase in GFR the urine production remained relatively low. It $1 \mathrm{~s}$ of interest that in the only dog with inltial high and constant GFR and ERPF values, the urine production decreased. So in all experiments in group II the water reabsorbtion improved during the ex-vivo perfusion.

In most kidneys of group II subnormal filtration fractions were measured after $\mathrm{s} 1 \mathrm{x}$ days preservation. In successful human allotransplantation subnomal filtration fractions have also been reported $(179,180,181)$, although the total ischaemic time of those kidneys varied between 16 and $55 \mathrm{ml-}$ nutes. Herdman et a1. (179) explained this phenomenon by dilatation of glomerular efferent arterioles in the presence of normal or partially closed afferent arterioles. Hereby the lowered filtration pressure caused a decrease in GFR whlle the blood flow along the proximal tubules continued und is turbed.

In these preservation experiments the FF, measured at one hour after implantation, seemed to have a predictive value for the viabli1ty of the kidney. As shown in figure IV, 5 all klaneys with life-sustaining function had low FF values, whereas the non-viable kldneys of the control group had a high FF, which obviousiy indicates absence of tubular function.

The experiments described in this chapter 11lustrate the beneficial effect of an intermediate normothermic ex-vivo 
perifusion once more. Although a preservation time of six days was reached, there was no question of true preservation 10 group II snce the klaney were connected again to the blood clrculation of the donor dog. However, the data gave valuable infomation useful for the replacement of the exvivo perfuslon by an artlifelal heart-lung circult, which was the next step in the preservation experiments. 


\section{BLOOD PERFUSION}

The alm of the experiments described in thls chapter was to investigate whether the benefit of nomotherinic perfusion halfway the preservation period was an intrinsle effect of the ex-vivo situation, or whether the same results could be achleved using a heart-Iung machine.

Materials and methods:

In elght dogs (Group III) kldneys were preserved by hypotheric perfusion for six days. On the third day of the preservation period the kidneys were normothermically perfused in a heart-lung machine. The experimental model is shown in figure IV, 1 . The heart-lung machlne was fllled with fresh alloblood ( $10 \mathrm{ml} / \mathrm{g}$ kidney weight) drawn from the carotid artery of a blood donor dog which was anaesthetised with nembutal ( $30 \mathrm{mg} / \mathrm{kg}$ intravenously) and treated with 400 IU heparine/kg and $1 \mathrm{~s}$ amoxicilline. The perfusion of the preserved kidney started within two minutes after prining of the circuit. After three hours blood perfusion the kidney was plushed with Eurocollins at $4^{\circ} \mathrm{C}$ and perfusëd in the Gambro ${ }^{(1)}$ machine with the same perfusate for another three days. The heart-lung machlne applied in group III was designed and constructed in the laboratorles of Prof. Nlzet (Llege, Belgum) (11) (Fig. $V, 1, V, 2)$. The axygenator was made of two concentric plexiglass cylinders flxed on the same bage. The venous blood was spread over the outer surface of the inner cylinder and the inner surface of the outer cylinder by a slowly turning disc. The blood, flowing down the cylinder was oxyzenated by a humidified mlxture of $95 \% \mathrm{O}_{2}$ and $5 \% \mathrm{CO}_{2}$ which was blown between the cylinders. The oxygenated blood was pumped upwards from the bottom of the oxysenator to the renal artery. In the arterlal line a blood fllter $(250 \mu \mathrm{m})$ 


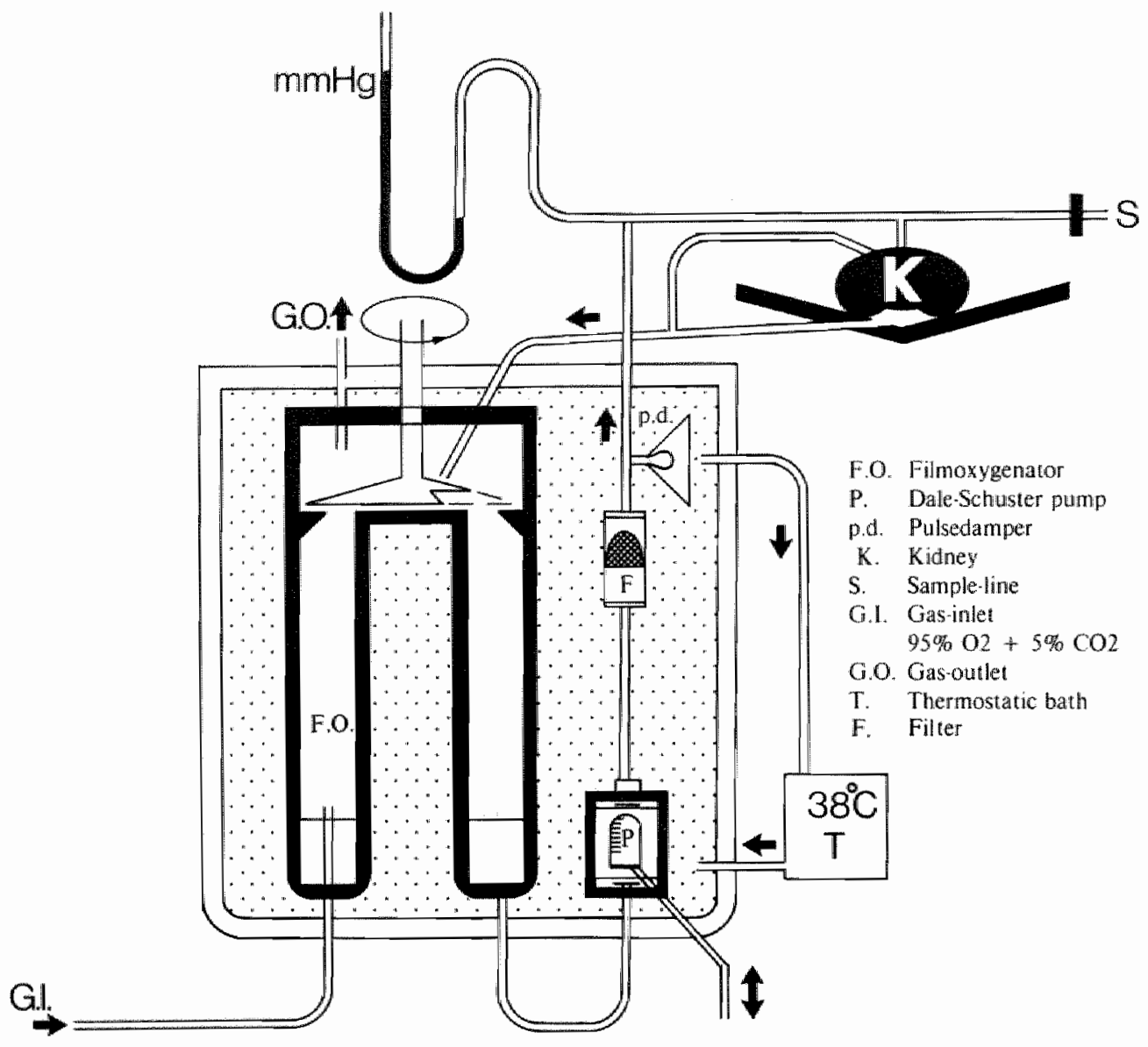

F1gure V, 1: Scheme of the heart-lung machine applied fior the intermediate perfuston in group III. The perfusion clrcult tncluded a fllm oxygenator and a hydraulic balloon pump (Dale schuster type). Halfway the six day preservation perlod the klaneys were perfused for three hours with fresh hepartnised alloblood. After three hours blood perfusion the kidneys were placed back on the Gambro machine. 


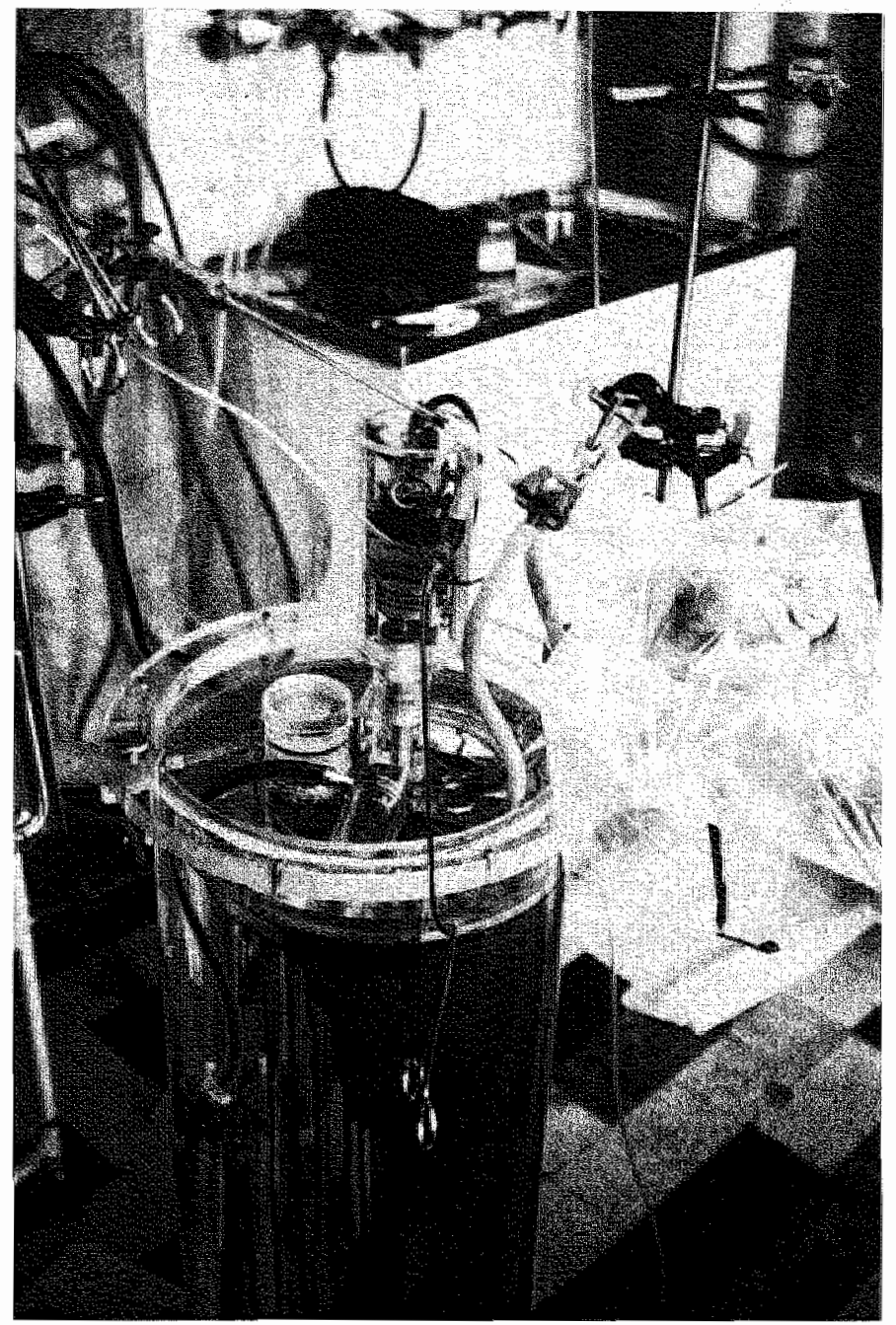

Flgure W, 2: Heart-lung machine for blood perfusion ln group III. The kidney lay In a shallow plexiglass bowl and was covered with a plastlc bag to malntaln sterility and to prewent dehydration (see flgure V,1). 
and a pulse damper were included. The Dale schuster type (13) blood pump was made as follows: wlthin a sma11 plexiglass cylinder with two light in- and outlet stalnless steel valwes, a balloon was constructed. This balloon - the finger tip of an operating flove - was fllied with saline solution and connected with a pressure tublng to a plston pump. The plstor of the pump regulated the volume of the balloon by hydraulic transmision. By varying the deflection of the plston the stroke rolume of the blood pump was altered (11). The blood pressure was measured at the end of the arterial Ine by a mercury manometre. The renal blood flow was determined by intemittent coliection of wenous blood in a calibrated plpet. The kldney lay in a shallow plexlglass bowl and was covered with a plastlc bag to malntion sterlity and to prevent dehydration. Blood leaking from the renal capsule was added contlnuously to the venous blood. The oxygenator and the blood pump were surrounded by a thermostatic water bath. Funally an Inframed lamp prevented cooling down of the kldney. Whroughout the blood perfuston a perfusion pressure of $120 \mathrm{~mm} H \mathrm{Hg}$ was malntalned. At the start of the perfusion $40 \mathrm{mg}$ promethazine ${ }^{*}$ per liter perfusate was added. At hourly intervals $5 \mathrm{ml}$ glucose solution (5 g/100 mil) was given to malntaln normal blood glucose levels.

Before each experiment the whole perfusion circult was sterlilsed with ethylen-oxyde gas. The ethylen-oxyde was removed by ventilation of the perfusion clroult with sterile alr durlng 10 days.

As in Broup II, GPR and ERPF measurements were done by clearance calculations. At the start of the lsolated blood perfustons in the heart-lung machine a single dose of 0.005 mC1 125 Iothalamate and $0.002 \mathrm{mCl} 131$ I-hippurate was added to the perfusate. Urine and blood samples were taken at hourly Interwals. After implantation and contralateral nephrectomy kldney function was assessed by dally measurements of serum

The action of promethazine is discussed $1 n$ chapter $\mathbb{I X}$. 
creatinine concentration. One hour after implantation GPR and ERPF were measured as in the control group (chapter III). Histological examination of the kidneys was performed at autopsy three weeks after implantation or after uraemic death. This was done in the same way as described in the control group (Chapter III).

Results:

During the hypothermic perfusion the same perfusion characteristics were found as in group II (Chapter IV). After implantation all kidneys regalned normal colour upon revascularisation. The mean diuresis measured at one hour after implantation was $5 \mathrm{ml} / \mathrm{h} / 100 \mathrm{~g}$ (range $2-15 \mathrm{ml}$ ), which was $\mathrm{s} 1 \mathrm{~g}$ nificantly lower $(p<0.01)$ than in the ex-v1vo perfused group (II). Although the diuresis was signiflcantly higher ( $p<$ 0.05) than in the control group (Chapter III), the urine production decreased to anuria within a few hours after implantation. In three out of eight dogs the diuresis recovered two days after Implantation. Only these three dogs had life-sustaining kidney function. In the three surviving dogs the mean serum creatinine concentration reached a maximum value of $890 \mu \mathrm{mol} / 1$. on day three (Fig. V, 3).

Most GFR and ERPF values, measured one hour after $1 \mathrm{~m}-$ plantation, were lower than 1 in group II and as in this group, no correlation with the serum creatinine concentration values could be demonstrated elther (Table $v, 1$ ).

As in the control and ex-vivo perfused group, the three surviving dogs had low flitration fractions after implantation (Fig. $V, 4)$. However, low flltration fractions $(0.11$ 0.50) were also measured in the flve dogs which did not prove to have life-sustaining kidney function (see discussion).

H1stology: In this group all non-viable kidneys ahowed a typlcal feature at autopsy. On blsecting the kidneys a hae- 


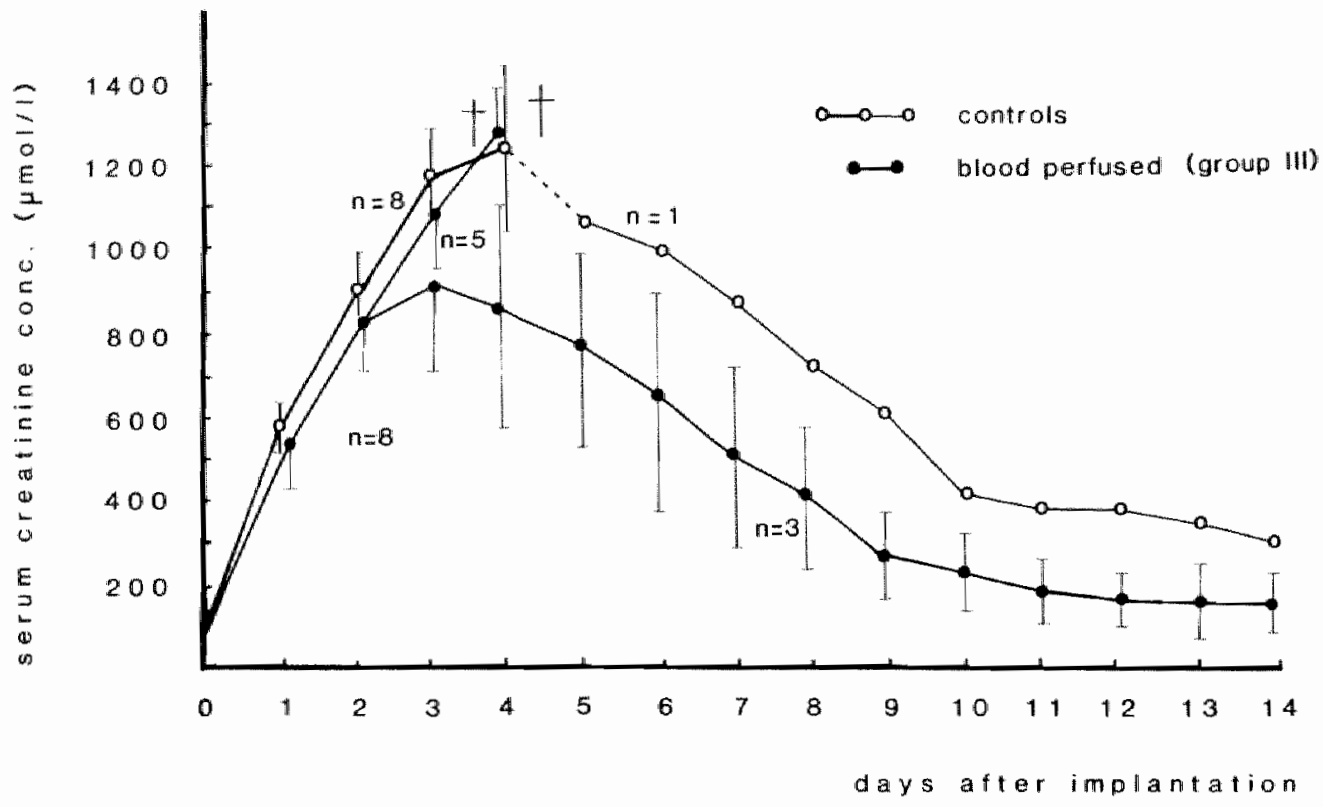

Flgure V,3: Serum creatinine concentration in group III (mean values $\pm S . D$. ). In the lsolated blood perfused group 3 out of 8 kldneys had life-sustalning kidney function. The results of the control group (I) with hypothermic perfusion only are also presented. 
Table V, 1: GLOMERULAR FILTRATION RATE, EFFECTVE PLASMA FLOW AND FILTRATION FRACTION IN SIX DAYS PRESERVED KIDNEYS ONE HOUR AFTER IMPLANTATION

GROUP III (heart-Iung perfused)

\begin{tabular}{cccc} 
dog & $G F R^{a}$ & $\operatorname{ERFF}$ & - \\
\cline { 2 - 3 } $1^{b}$ & 0.12 & 0.73 & 0.16 \\
$2^{b}$ & 0.86 & 3.34 & 0.26 \\
3 & 0.11 & 0.98 & 0.11 \\
$4^{b}$ & 0.04 & 0.08 & 0.50 \\
$5^{b}$ & 2.07 & 40.00 & 0.05 \\
$6^{b}$ & 0.51 & 4.38 & 0.12 \\
$7^{b}$ & 0.07 & 0.16 & 0.44 \\
8 & 0.08 & 0.41 & 0.20
\end{tabular}

a GFR and ERPF values were calculated in $\mathrm{ml} / \mathrm{mln} / 100 \mathrm{~g} k 1 \mathrm{dney}$ we 1.ght.

b These dogs had iffe-sustaining function. 


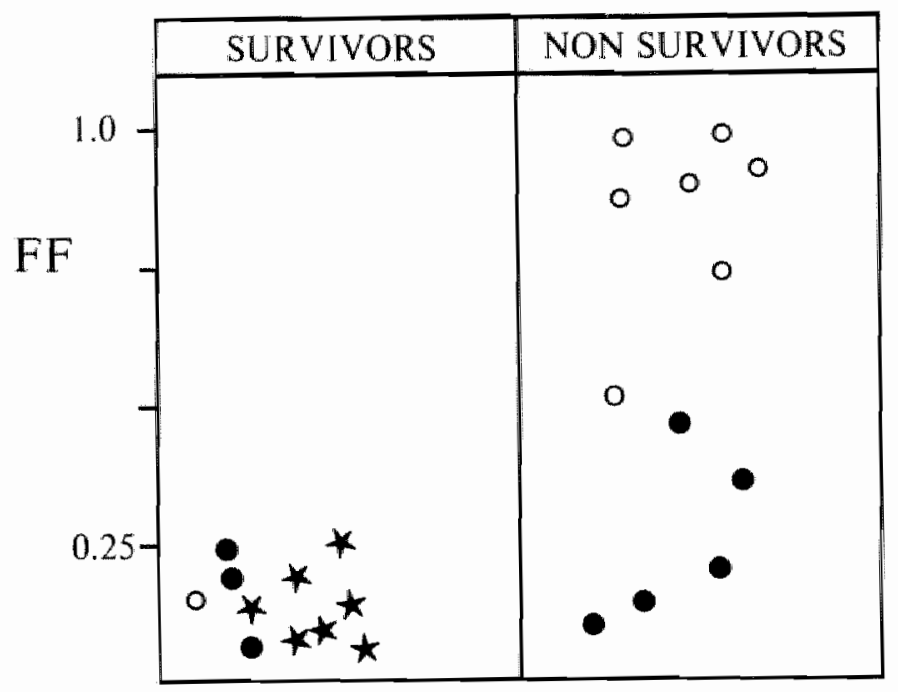

Flgure V, 4: In group III (1solated blood perfused) the 3 surviving dogs had low flitration fractions after implantation (-). However, low flitiration fractions were also measured $1 \mathrm{n}$ the 5 dogs which did not prove to have 11fe-susta1ning function (see discussion). For comparison the Fr values of the control group (o) and the ex-v1vo perfused group (*) are also presented. 


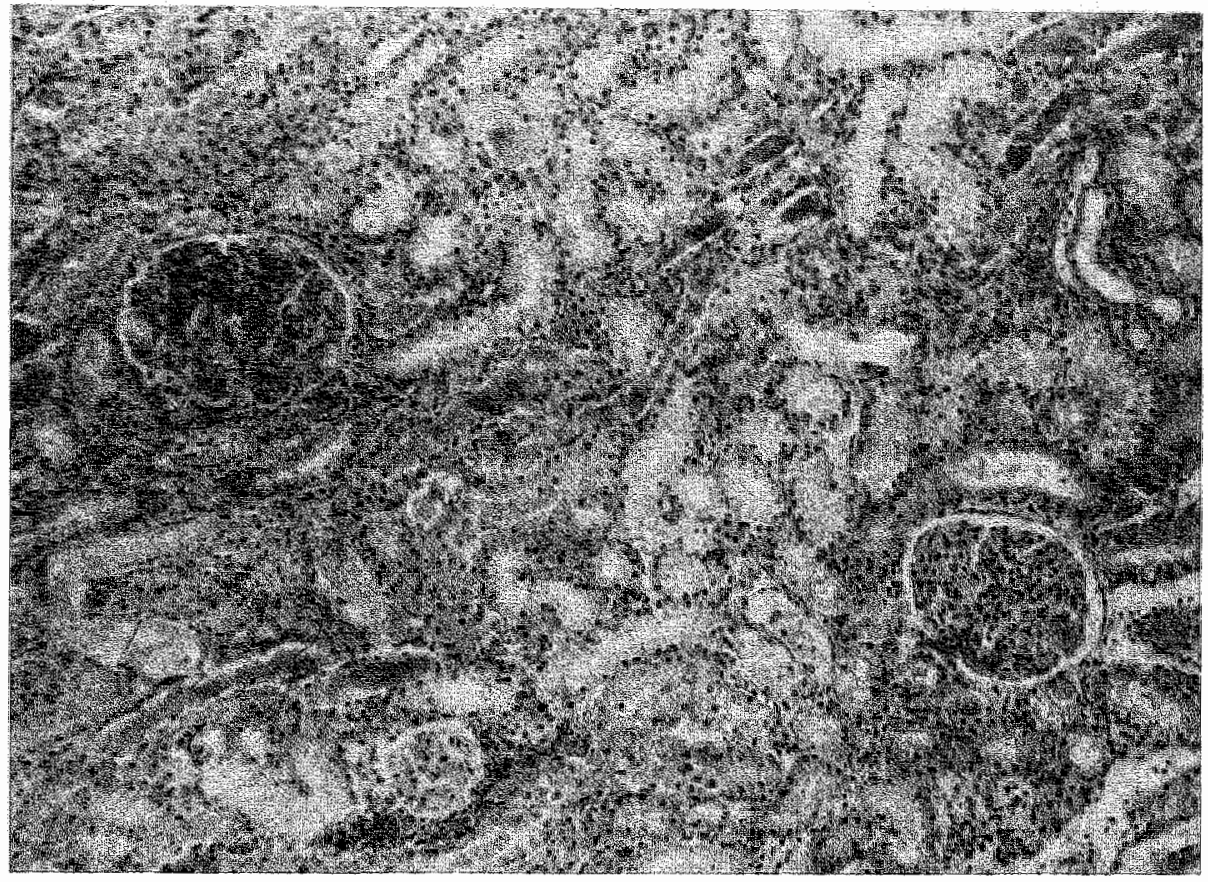

Figure V,5: In group III all non-viable kidneys showed a typlcal feature at autopsy. On blsecting the kidneys a haemorrhagic zone was observed between the cortex and the medulla. In histological sections of these kldneys, bleeding around vessels was assoclated with glomerular and tubular damage. In some places unaffected blood vessels tobether with nomal glomerull and tubules were seen (Hematoxillin/ Eosin ca. $250 x$ ). 
mormaglc zone was observed between the cortex and the medulla. In histologlcal sections of these kidneys bleeding around vessels was assoclated with glomerular and tubular damage. In some places unaffected blood vessels together with normal glomerull and tubulus were seen (Fig. $V, 5$ ).

At autopsy of the surviving dogs, three weeks after implantation, small traces of the typical haemorrhagic zone were observed on blsecting the kidneys. Apart from this the histologlcal sections showed normal morphology as in group II.

Isolated blood perfuslon. During the 1ntermediate blood perfusion in the heart-lung machine the mean arterial pressure was kept at $120 \mathrm{~mm} \mathrm{Hg}$. In all kidneys the renal blood flow increased steadily from $165 \pm 21 \mathrm{ml} / \mathrm{mln} / 100 \mathrm{~B}$ in the first hour to $260 \pm 49 \mathrm{ml} / \mathrm{min}$ in the third hour (FIg. V,6). After three hours perfusion macroscoplc haemolysis was detected in the perfusate of the heart-lung machlne. During the first hour of blood perfusion, GFR and ERPF values were higher than those in group II. However, after a slight increase in the second hour all values dropped to the same level or even lower levels than the first hour values (FIg. V,6). No correlation could be demonstrated between the values of GFR and ERPF and 1ife-sustalning function after 1mplantation. As in group II a low filtration fraction was measured during the blood perfusion. In most experiments the urine production decreased slowly throughout the perfusion $(N 1 g, V, 6)$.

\section{D1scussion:}

In thls serles experiments successul six day kldney preservation was not achleved. Only three out of elght dogs survived after autotransplantation. The intermediate blood perfusion performed in a heart-lung machine, including a flim oxygenator and a hydrollc balloon-pump, had not the same beneficlal effect as the normothermic ex-vivo perfusion 


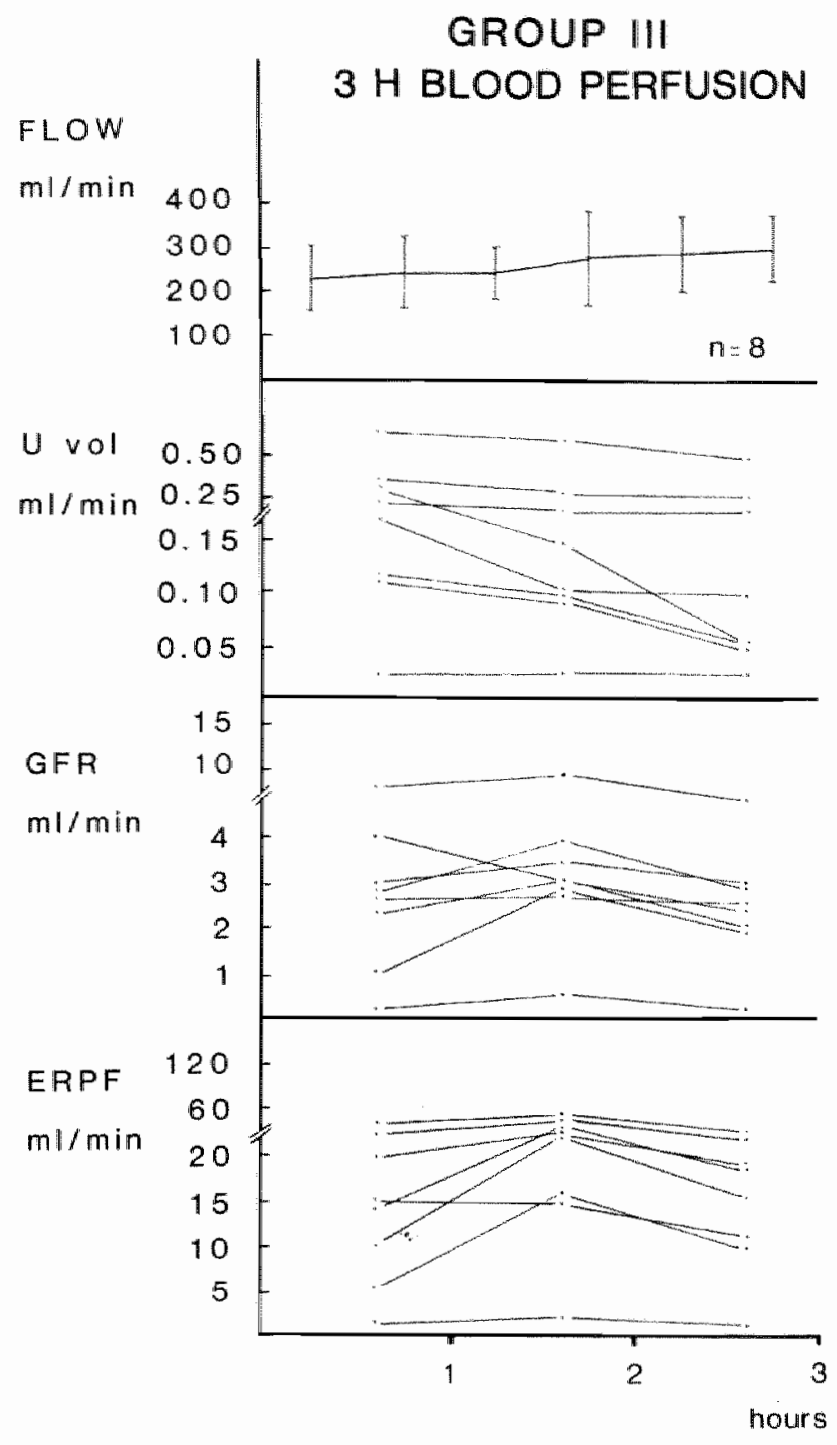

F1gure V,6: Perfusion parameters of the blood perfusion halfway the six day preservation perlod in group III. The renal blood flow is presented in mean values $\pm S . D$. The urine production, the glomerular flitration rate and the effective renal plasma flow are presented for each perfusion experiment. The filtration fraction showed no variation and was low throughout each perfusion (range 0.06-0.25). FF values are not presented in the flgure. 
In group II.

Isolated blood perfusions of kidneys as applied in the experiments of group III have been used by several authors but malnly for physlologlcal and pharmacologlcal studies $(20,21)$ (see chapter I, 1). Few authors have reported attempts to preserve kidneys for transplantation with nomothermic preservation techniques $(16,30,33)$. Their data Ind1cate that the functional integrty of such lsolated kidneys can be preserved for approximately elght hours. Factors which might be responsible for organ fallure at longer perfuston periods are lack of substrates and hormones, accumulation of waste products and damage caused by the mechanlcal way of perfusion ( 30 ). In the experiments of group II these drawbacks of normothermlc preservation were limited by the shorter time of blood perfusion. Moreover the damage induced by the mechanical perfusion was reduced (N1zet et a1.) by the application of a Dale-Schuster type hydraulic balloon pump lnstead of a conventional roller pump.

In the heart-lung machine a mean arterial pressure of $120 \mathrm{~mm} \mathrm{Hg}$ was used throughout the blood perfusion. This pressure was routinely used in the perfusion circuit of Prof". Nizet. Although GFR and ERPF were higher than in the ex-w1vo perfused group, the values were st1ll low ln proportion to the total renal blood flow (chapter IV). The higher perfusion pressure applied in the isolated blood perfusion accounted for the higher Inftial GFR and ERPF values. However, the GFR and ERPF decreased durling the third hour, whlle a steady increase in blood flow was measured. This suggests that the extraction of 131 I-hIppurate was impaired even more. In addition the macroscople haemolysis that occurred at the end of the blood perfusion had a detrimental effect on the tubular fraction.

other unvestigators have described a similar decrease in GFR and tubular function in lsalated blood perfusion of notpreserved kldneys $(15,17,20)$. Several explanations for the Impalred renal function were glven. N1zet et al. (12) stated 
that during the course of the perfusion the release of vasodilatating factors in the heparinised blood reduced the resistance of pre- and postglomerular arterloles, leading to oedema and increased tubular pressure. Thereby a decrease in GFR and hippurate extraction might occur. Waugh and Kubo (20) emphasized that microembolisation by fat globules was responsible for the decline in GFR, since addition of the fat emulsifying agent Pluronic-F68 significantly reduced the decline in GFR. Berkowltz et al. (182) and lateron Gagnon et al. (22) also reported decline in $Q F R$ and tubular function in spite of increasing blood flow. Dilatation of efferent arterioles, which modulate the hydrostatlc pressure in the glomerul1, and an increased medullary blood flow were thought to be responsible for the functional alterations after several hours of perfusion.

In this study the flitration fraction measured at one hour after implantation did not have such a predicltive value for the viability of the kidney as in the other groups. Flgure $V, 4$ shows that klaneys in group III with low filtration fractions did not prove to have life-sustalning function after 1mplantation. An explanation for this phenomenon was found in kidney histology at autopsy. Haemorrhag1c infarction, which was especially present in the outer medulla$\mathrm{ry}$ zone, was considered to be responsible for the tubular and glomerular damage. These data suggest that the heartlung perfusion in group III had been beneflolal to the tubules but on the other hand, had caused endothellal damage.

These findings might explain the low flitration fractlons after implantation, indicating the presence of active functioning tubules, and the anurla that occurred afterwards caused by the vascular damage. The endothellal damage was probably caused by the higher perfusion pressure applied during the mechantcal blood perfusion (120 versus 90-100 mmHB in group $\mathrm{II}$ ).

In conclusion it was found that the intermediate blood perfusion had to be Improved and that the experiments des- 
cribed here could not answer the question whether the normothemic ex-vivo perfusion could be replaced by an artificial blood perfusion. The experiments were useful for the design of a new perfusion circult especially adapted to the requirements of the intermediate normothermic blood perfusion. 
Based on the experience obtained with the perfusion clmcult of Prof. Nizet (Llege, Belglum), a modifled heart-lung machine was bulit.

To reduce the blood damaging effect of the mechanical way of perfusion, the design of the perfuston clroult had to come up to the following demands:

a) the length of tubling should be kept as short as passible and,

b) the blood gas interface should be avolded or reduced to a minimum $(183,184)$.

As in the perfusion clroult of Prof. N1zet a Dale-Schuster type hydraulic balioon pump was used instead of a roller pump. Besides the less traumatic effect on the blood, this pump had another advantage: it could be placed in a waterbath. Hereby the use of a heat-exchanger could be avolded.

For the intermediate blood perfusion in these experiments some other speciflc requirements were necessary:

a) It should be possible to sterlilse the circult,

b) blood (heparinised) leaking from the capsule of the perfused kidney should be re-added continuously to the circulating blood volume,

c) the priming (flling) of the clrouit should be performed quickly and it should be able to read the primling volume,

d) It should be possible to measure both the perfusion pressure and the renal blood flow, and flnally to take blood samples and to collect the produced urine.

Perfusion clrcult: As shown in flgure VI, 1 the actual perfusion clrcult was composed of a disposable reservolr (polyvinylchloride, RV 500-1, Sclmed, Minneapolis, Mn), the hydraulic balloon pump, a dsposable membrane oxygenator (Kolabow $4002 \mathrm{~A}$, Scimed, $\mathrm{M} n$ ), a cone-shaped plexiglass filter with a single-layer nylon filter $\left(20 \mathrm{~cm}^{2}, 200 \mu \mathrm{m}\right.$ pore $\left.\mathrm{slze}\right)$ and an 


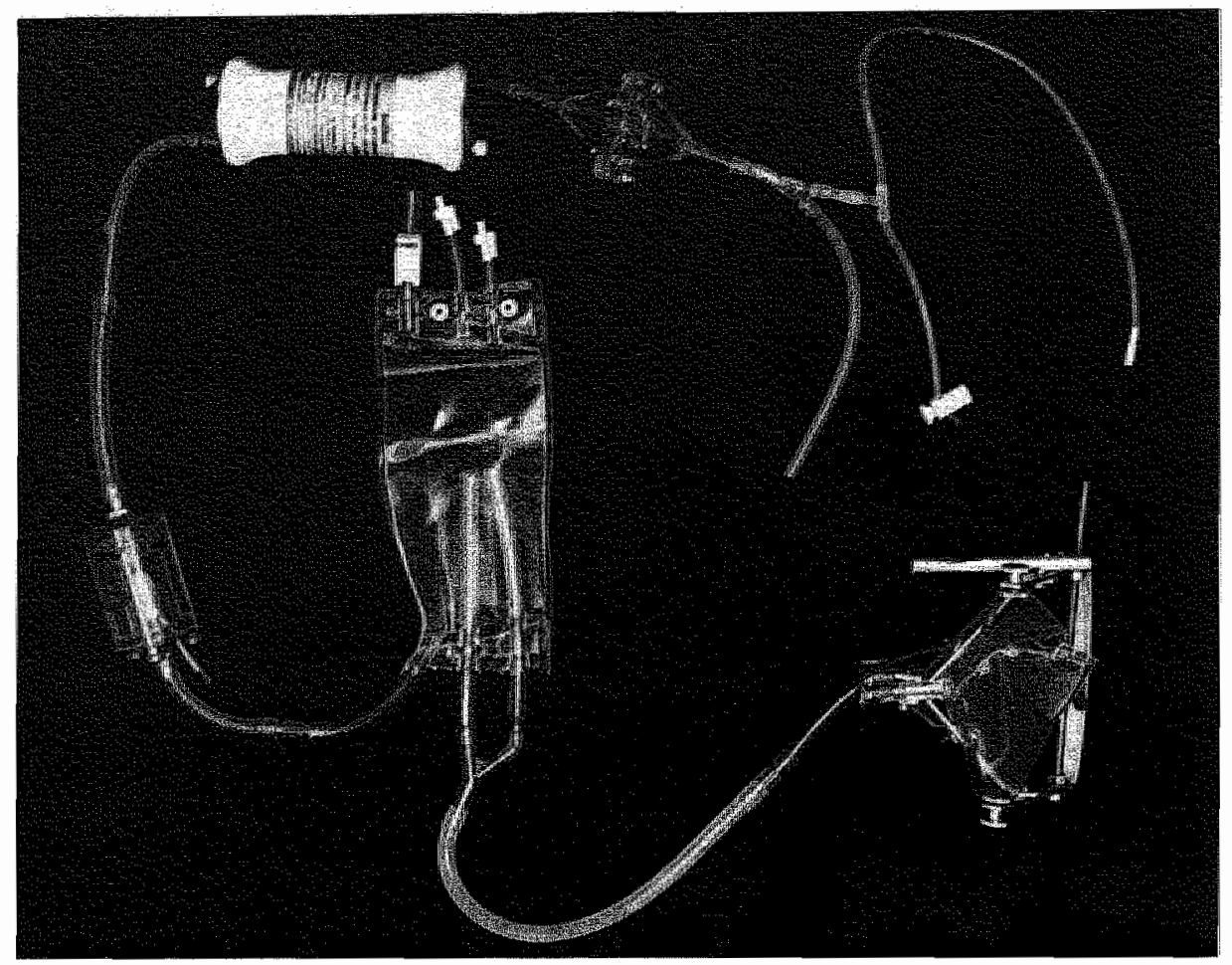

Flgure VI, I: Clrcult for normothermic blood perfusion of canine kidneys. The perfusion clrcult lncluded a membrane oxygenator (Kolobow 400, 2A, Sclmed), a hydraulic balloon pump (Dale schuster type), a single-layer nylon blood fliter, a venous reservolr and an organ chamber. The organ chamber was made of a dispocable venous reservolr (RV 500-1, Sclmed) opered on 1 ts long slde, spread out check-formed and flxed in an alumintum fome. 
organ chamber.

The balloon in the blood pump was made of a flngertip of an operating glove and 1 te wes replaced after each perfusion. The nylon fllter in the blood fllter was also replaced after each perfusion. The organ chamber was made of a alsposable venous reservolr (RV 500-1, Selmed) which was opened on $1 \mathrm{ts}$ Long side, spmead out check-formed and flxed $1 \mathrm{n}$ an alumintum frame. Hereby a kidney-shaped space was created, under which blood from the renal wein and from leakage from the renal capsule could be collected. The ureter cannula was led out through a separate hole in the organ chamber. Humidity was malntalned by covering the upper slae of the kldney with a small plece of plastlc and by folding up the organ ohamber.

By this construction the blood gas Interface was limited to a few square centimeters just below the klaney. The parts of the perfusion clrcult were connected with s1licone tublng with a total length of one meter. The arterial line was provided with a sample line and a connection for a mercury manometer. The hydraulic balloon pump, which was the same as described in chapter $V$, was provided with a flow indicator; the amplitude of the pump-piston, which was proportional to the stroke valume of the pump, was Indlcated by a needle on a callorated scale.

Preparation for the blood perfusion: The perfusion c1rcult as shown In $\mathrm{r}$ Gure VI, I was constructed under sterwle cond thons and fixed on a heary rrame of lron and plex1glase. The venous reservolr was plxed on a plextglass plate on whlch the priming volume roughly was indloated. "The balloon of the pump was fllled with Pluld and connected via a pressure tubling with the pliston-pump. Next the lron frame with the perfusion clrcult was suspended from the celling above a thermostatic water bath $\left(38^{\circ} \mathrm{C}\right)$. The pertusion clrcult was kept in postition by a counterwelght connected va a pulley with the 1 ron frame. 


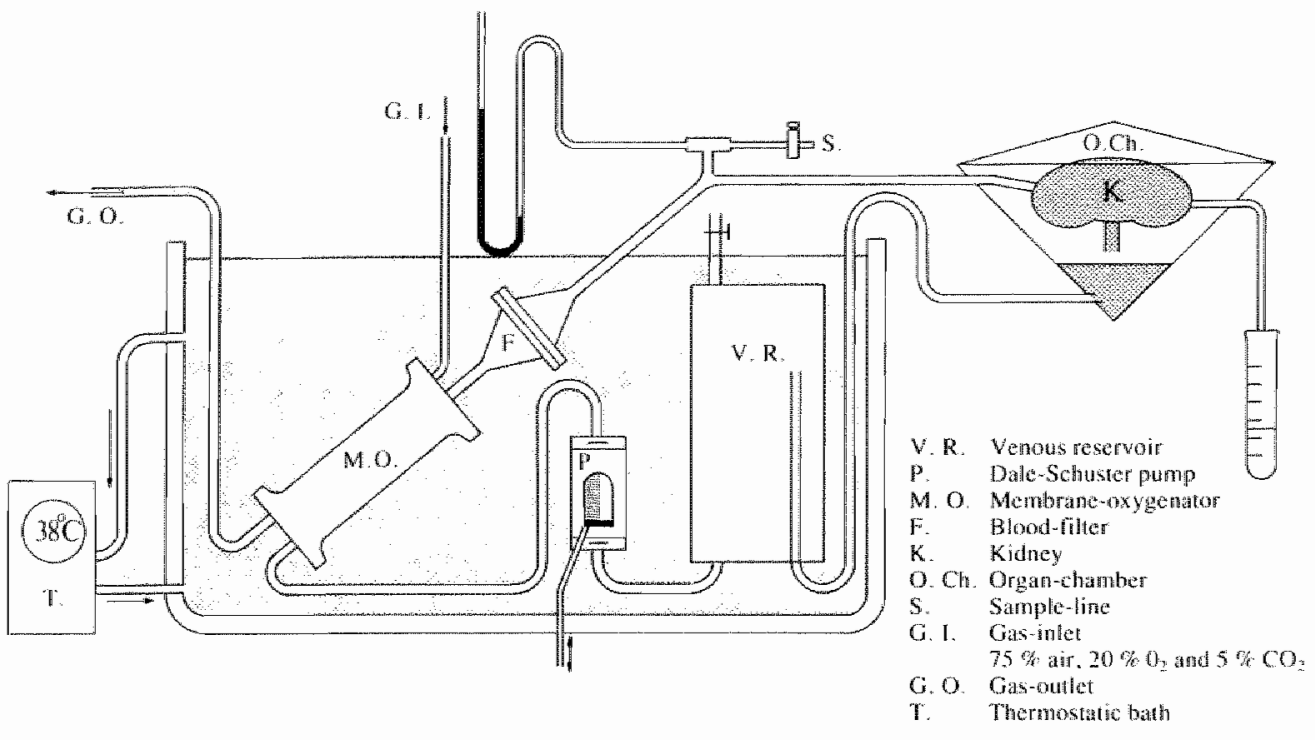

Flgure VI,2: Scheme of the modifled heart-lung machine for 1solated blood perision of cantine kidneys. 
An aquarium was used as waterbath: (I used the aquanium or my wife and so I prevented her from keaping turties in 1t, for I hate those creatures). The sample Ine and the tubing to the mercury manometer were filled with sterile saline.

Isolated blood perfusion: As described 1 in chapter $V$ the heparlnised blood was drawn from the carotid artery of a donor dog. The venous reservolr of the heart-lung machlne was papld1y filled with donor blood. The perfusion of the preserved kidney started within two minutes after priming of the elroult.

The blood pump was adjusted to a peruston pressure of $100 \mathrm{~mm} H \mathrm{Hg}$. The blood was oxygenated in the membrane oxygenator by air to which $20 \% \mathrm{O}_{2}$ and $5 \% \mathrm{CO}_{2}$ was added to malntalin an axygen saturation of about $95 \%$ and a pH of 7.4 . At the start of the perfusion $20 \mathrm{ml}$ of a solution contalning $0.21 \mathrm{~g}$ sod1umcarbonate and $0.75 \mathrm{~g}$ glucose was added per 1iter perfusate. Now the whole clrcuit (except the argan chamber) was submerged in the themostatic waterbath. Hereby the als in the venous reservolr was removed. A scheme of this situation ls shown in flgure VI, 2. Next the priming valve of the venous reservolr was closed, and by a short flrm push on the venous reservolr the alr-bubbles in venous line were pressed back into the organ chamber. Hereby the level of the blood in the organ chamber was the same as that of the fluld in the water bath. Finally an infra-red lamp dipected to the kidney maintalned nomothermia of the k1dney. A plcture of the lsolated blood pereusion $1 \mathrm{~s}$ shown $1 \mathrm{n}$ ifgure VI, 3 .

Results of 1solated blood perfuslons with not-preserved k1dreys: To examine the qualities of this newly bullt perfusion system four kidneys were perfused during three hours. A warm Ischaemia time of two minutes was needed for nephrectomy, insertion of an arterlal cannula and transportation of the 


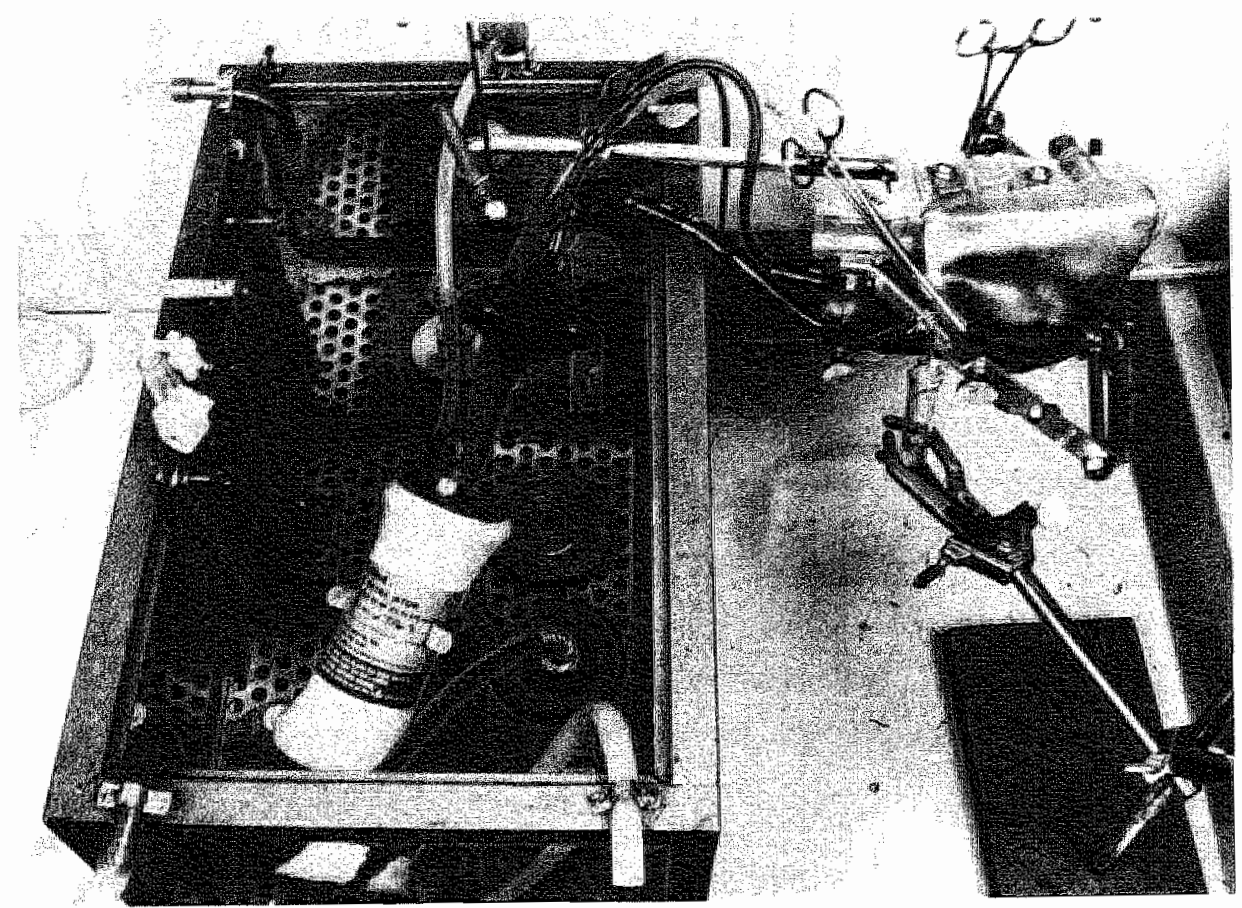

Flgure VI,3: Modifled heart-lung machine for blood perfusion. The whole clrcult except the organ chamber was placed In a themostatic waterbath $\left(38^{\circ} \mathrm{C}\right)$. The blood/gas interface was limited to only a few square centimeters just below the kidney (see $F 1 B$. VI, 2$)$. 


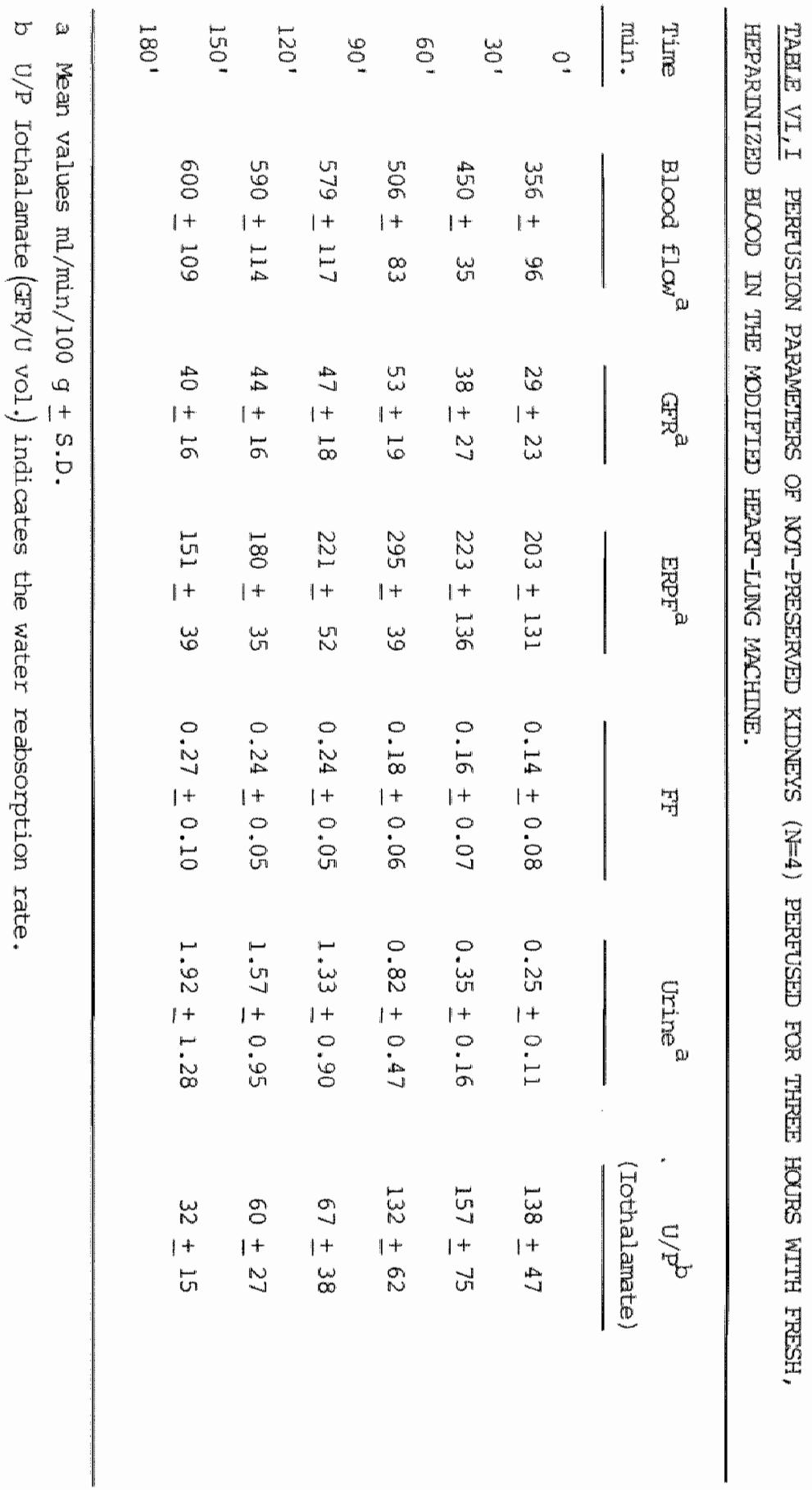


kidney to the perfusion machine. During the perfusion blood flow was measured and $G$ FR and ERPF values were determined as described in chapter $V$. The urine and blood samples were taken at 30 minute intervals.

The results are summarized in Table VI, 1., which gives an Impression of the functional capacity of the isolated perfused kidneys. The results are similar to those reported by other investigators (15, 20). They described supranomal blood flow and increasing urine production which might be due to a progressive loss of antidiuretic hormone. During the second part of the perfusion $G F R$ and the ERPF decreased while a steady increase of blood flow was measured. As discussed in chapter $V$ this might be explained by a reduced resistance of pre- and postglomerular arterioles, leading to oedena and increased tubular pressures (12).

It was concluded that the new perfusion machine, as described in this chapter, was well adapted to the special requilements of a nomothermic kidney perfusion halfway a hypothermic preservation period. 
In this chapter the flrst experlences with the newly bullt heart-Iung machine in the six day preservation model are described. The pllot studies are divided in four small groups.

a. In four dogs the right kidney was preserved by hypothermic perfusion in the Gambro machine for $s 1 x$ days. On the thind day of the preservation perlod the kidney was normothermicaliy perfused with whole blood from an unrelated donor dog. The experimental model is shown in figure IV, I. The intermediate blood perfusion in the modified heart-lung machlne was performed as described in chapter VI. After three hours blood perfusion the kIdneys were flushed with Eurocolilns at $4^{\circ} \mathrm{C}$ and perfused In the Gambro(8) machine for another three days. In these pllot studies the viablity of the preserved kidney was only assessed by survival after implantation and serum creatinine measurements.

In this group only one out of four dogs had life-susta1ning kidney function after implantation and contralateral nephrectomy. The only survivor had a maximum serum creatinine concentration of $490 \mu \mathrm{mol} / 1$ on the third day after implantation. At the start of the intermediate blood perfusion the kldneys regalned their normal colour and produced urine within flve minutes. However in this group the perfusion characteristics differed strongly from those described in chapter $V$ and VI. After 15 to 20 minutes perfusion a marked decrease in blood flow was observed (F1g. VII, 1, continuous line). During the second and third hour of the perfusion the blood flow increased slowly to supranormal values. The urine production, GFR and ERPF values followed the blood flow 


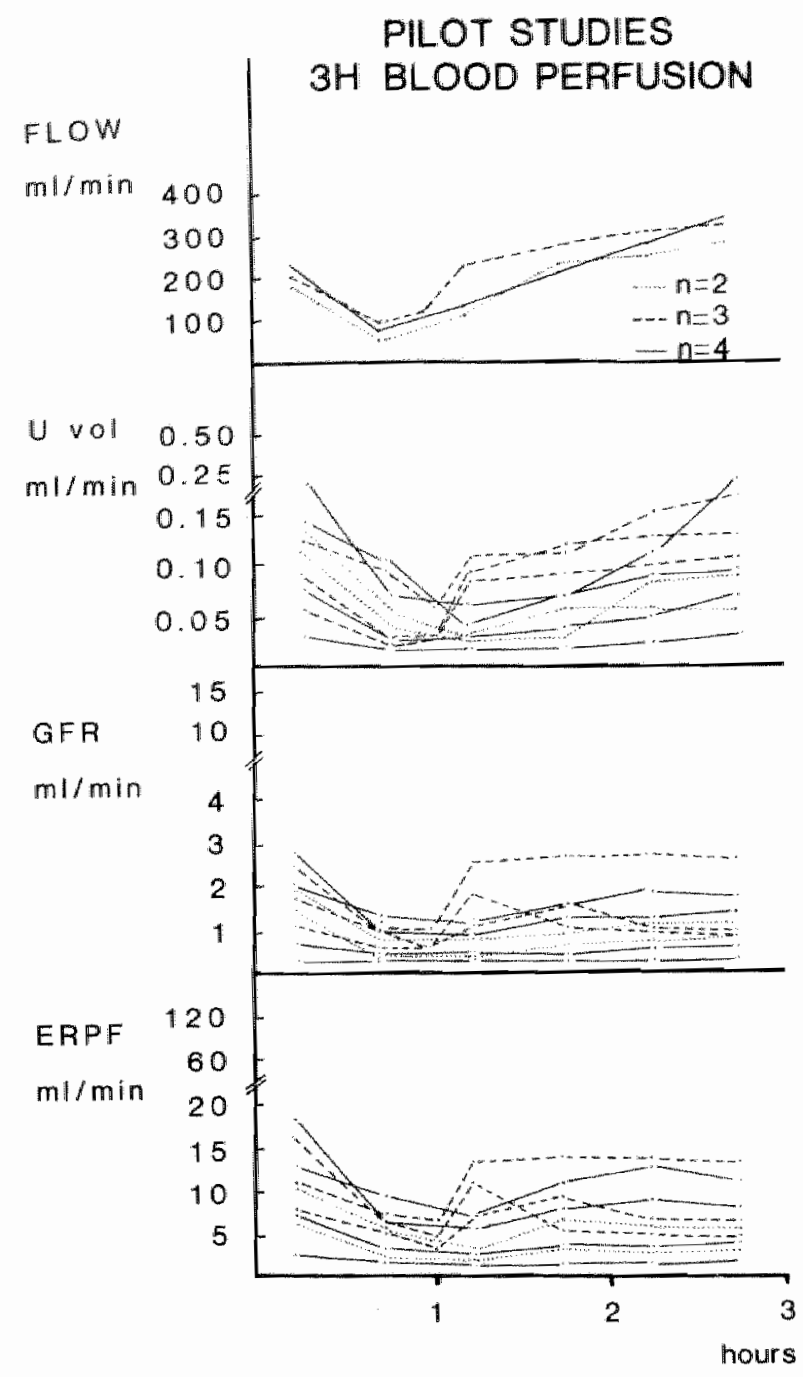

Flgure VII I: Perfusion parameters of the blood perfusion halfway the 6 day preservation period in the pliot studies. Durlng the flirst part of the blood perfusion, a severe vasoconstriction was measured (continuous line). Addition of phenoxybenzamine $(n=2)$ aid not reduce the decrease in blood flow (dotted 1ine). In 3 experiments mannitol was given after one hour perfusion (broken line). This resulted in an increase in the renal blood flow. In all experiments the other parameters followed the blood flow. 
pattern; after a decrease they moreased slowly to their inftial values at the end of the perfusion (Fig. VII,1). The blood perfusions were technically well performed without any macroscopic haemolysis. The unexpected decrease in blood flow was probably due to vasoconstriction and was thought to be responsible for the poor results after implantation. So 1 f there had been any beneficial effect by the blood perfuston itself, this was masked by the vasoconstriction during the filst part of the perfusion. The possible mechanism of the vasoconstriction w11 be discussed in chapter IX.

b. In other pilot studies attempts were made to counteract the vasoconstriction during the intermedlate blood perfusion. In two experiments $20 \mathrm{mg}$ phenoxybenzamine (D1benzyline ${ }^{(B)}$ per liter perfusate was added at the start of the three hours nomothemic perfusion. However this vasodilating drug did not influence the marked decrease in blood flow during the first hour of the blood perfusion. After implantation of these kidneys anurla occurred and the dogs died uraemic. As in the former four experiments the glomerular filtration rate and the effective renal plasma flow decreased in proportion with the blood flow. These values remalned low during the second and third hour of the blood perfusion (FIB. VII, 1, dotted line).

c. In the next experiments the effect of hyperosmolar mannitol on the decreased blood flow was examlned. It has been demonstrated by other investigators (185) that hyperosmolar mannitol induces a decrease in renal vascular resistence in ischaemic damaged kidneys by reducing t1ssue- and endothellal cell swelling. According to other authors (186) manntol would also have a vasodilator effect in ischaemic kidneys, medlated mainly by increased prostacyciln ( $P G I_{2}$ ) activity. In three preservation ex- 
periments $20 \mathrm{~m} 1$ mannitol solution $(20 \mathrm{~g} / 100 \mathrm{ml})$ per llter perfusate was $\mathrm{g}^{1}$ ven arter the irst hour of the normotherric blood perfusion. In these perfusions the blood flow Increased upon infusion of the mannitol solution (F1g. VII, 1, broken line). Inltially the glomemuar filtration rate and the effective renal plasma flow increased in proportion with the blood flow. In two experiments however, these values decreased during the third hour of the perfuston and in one case they remained constant.

In the last mentioned experiment the dog survived after the six day preservation period with a maximum serum creatinine of $400 \mu \mathrm{mol} / \mathrm{l}$ on day two. After implantation the other two kianeys had a weak consistency despite firm pulsations of the renal artery. These kidneys never produced urine. These experiments gave evidence that mannitol was effective in reducing the vascular resistance of poorly perfused kidneys. On the other hand mannitol seemed to have a detrimental effect on the kidney during prolonged perfusion in the heart-lung machine. The latter effect might be explained by a progressive dehydration of kidney celis by the hyperosmolar perfusate.

d. Finaliy in some pilot experiments the vasoconstriction durlng the intermediate blood perfusion was influenced by the addition of carbachol 1.e. a vasodilating drug with direct action on the vessel wall. Mannitol was g1ven just durlng the last minutes of the perfusion. In these experiments the vasoconstriction was functionally antagonised and the dogs survived after implantation. This pliot study was extended to a series experiments. The results are presented in chapter VIIT. 
In thls chapter a series of 11 experiments (group IV) is described in which dog klaneys were preservea by hypothermic perfusion and 3 hours isolated blood perfusion halfway the preservation period (see experimental model, Esg. IV, 1). As In the control group the hypothermic perfusions were performed In the Gambro machine (Chapter III). The isolated normothermic blood perfusion was performed according to the technique described in chapter VI. Based on the experiences in the pliat studies (Chapter VII) an attempt was made to Improve the blood flow during the blood perfusion.

At the start of the blood perfusion $200 \mu \mathrm{B}$ carbachol per liter perfusate was added and during the last five minutes of the perfuston $20 \mathrm{ml}$ mannitol solution $(20 \mathrm{~g} / 100 \mathrm{ml})$ per 1iter perfusate was administered. The perfuston pressure in the heart-lung machine was $100 \mathrm{~mm} \mathrm{Hg}$. Durlng the blood perfusion GER and ERPF values were determined as in group IIT. Urine and blood samples were taken at 30 minute intervals. After the preservation period of six days implantation followed by contralateral nephrectomy was performed. As in the other experimental groups the kidney function was assessed by dally serum creatinine measurements. GFR and ERPF were also measured one hour after implantation as described in chapter III. In the same way follow up determinations of GFR and ERPF were performed at three, ten and 21 days after $1 \mathrm{~m}$ plantation in the last flve dogs of this group (IV). Three weeks after implantation the dogs were sacriflced. After autopsy histologlcal examination of the kidney blopsies was performed. 


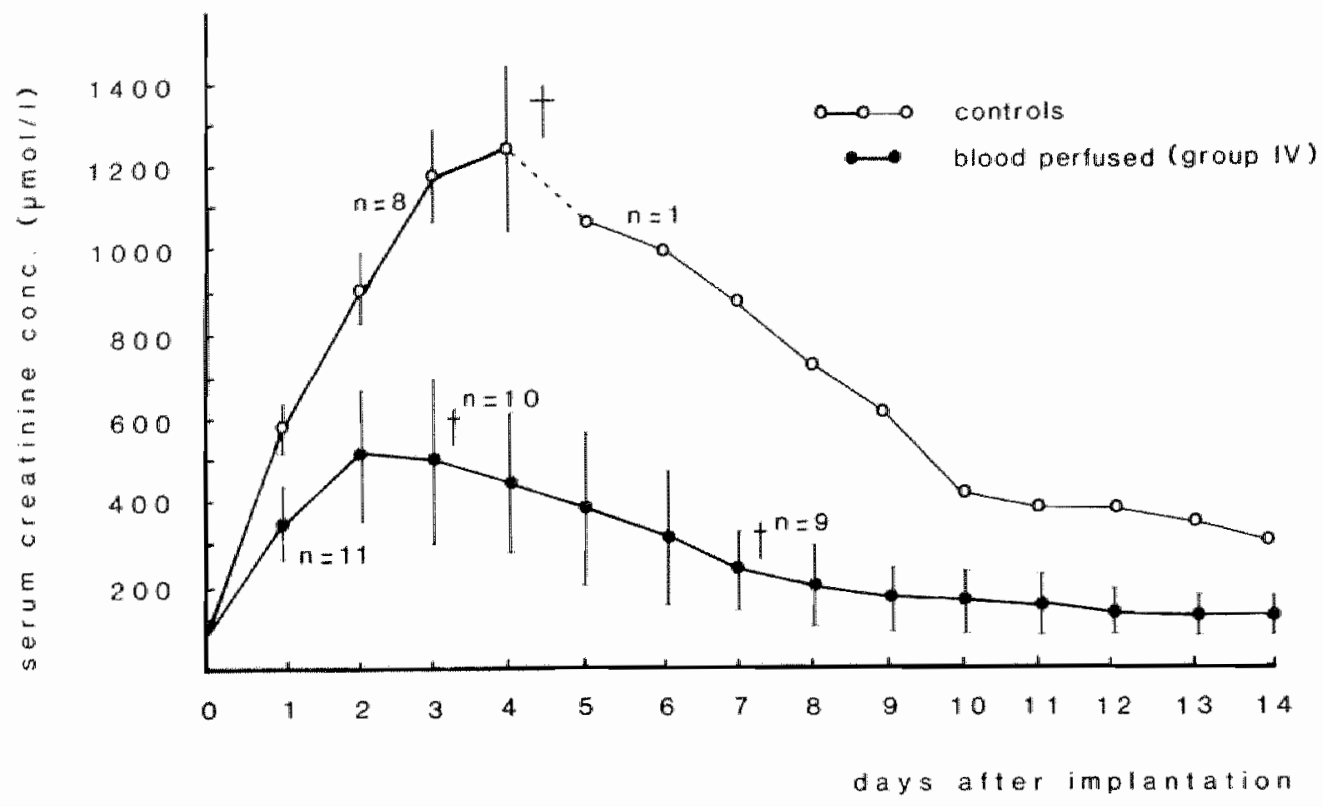

Flgure VIII,1: Serum creatinine concentration in group IV (mean values \pm S.D.). In thls group all dogs had life-sustalning kldney function. Two dogs had to be sacrificed for technical reasons. The results in the control group (I) with hypothermic perfusion only, are also presented. 
Hypothermic perfusion: During the hypothermic perfusion the same values of perfusion pressure, perfusate flow and $p H$ were measured as in the control group (I) (FIg. III,3). APter the normothermic ex-vivo perfusion the same perfusion parameters were measured as during the first part of the hypothermic perfusion.

Survival after implantation: Upon revascularisation all kidneys regained normal colour and produced immediately urine. At one hour after Implantation the urine production was signiflcantly higher ( $p<0.01$ Wilcoxon test) than in the control group and than in group III (chapter III, V). The urine production averaged $24 \mathrm{ml} /$ hour (range $4-51 \mathrm{ml} /$ hour) and was not slgnificantly different from that in group II (Chapter IV). In this group nine out of 11 dogs survived in a healthy condition. Unfortunately two dogs had to be sacrificed at respectively three and seven days after implantation because of wound dehiscence and urine leakage (technleal fallures). The serum creatinine values followed the pattern of the other dogs. In this group the mean serum creatinine concentration returned to normal within two weeks after implantation and had a maximum value of $533 \mu \mathrm{mol} / \mathrm{l}$ (range 279-885 $\mu \mathrm{mol} / 1$ ) on day two (F1g. VIII, 1). No significant difference (W1licoxon test) was observed between the mean serum creat1nine concentration values after implantation in this group (IV) and group II (FIg. IV,4).

Kidney function after Implantation: GFR and ERP values measured at one hour after Implantation are shown in Table VIII,1. As in the ex vivo perfused group (Table IV, 1) much variation was found among these values and the Individual values did not correlate with the serum creatinine concentration level after implantation. As shown in flgure VIII, 2 al1 kidneys had low filtration fractions after implantation 
TabIE VIII, 1: GLOMERULAR FILTRATION RATE, EPFECTIVE RENAL PLASMA FLOW AND PILTRATION FRACTION MEASURED IN SIX DAYS PRESERVED KIDNEYS ONE HOUR AFTER IMPLANTATION

\section{GROUP IV (modified heart-lung perfused)}

\begin{tabular}{rrrr} 
dog & GFR $^{2}$ & $\mathrm{ERPF}^{\mathrm{a}}$ & $\mathrm{FF}$ \\
\cline { 2 - 3 } 1 & 2.85 & 26.40 & 0.11 \\
2 & 0.53 & 3.95 & 0.13 \\
3 & 14.45 & 77.52 & 0.19 \\
4 & 5.47 & 49.66 & 0.11 \\
5 & 3.48 & 19.05 & 0.18 \\
6 & 1.17 & 10.71 & 0.11 \\
7 & 4.52 & 30.64 & 0.15 \\
8 & 3.40 & 13.73 & 0.25 \\
9 & 1.74 & 7.65 & 0.23 \\
10 & 1.72 & 8.67 & 0.20 \\
11 & 0.15 & 0.55 & 0.27
\end{tabular}

a GlF and ERPF values were calculated in $\mathrm{ml} / \mathrm{mln} / 100 \mathrm{~g} \mathrm{kldney}$ welght. 


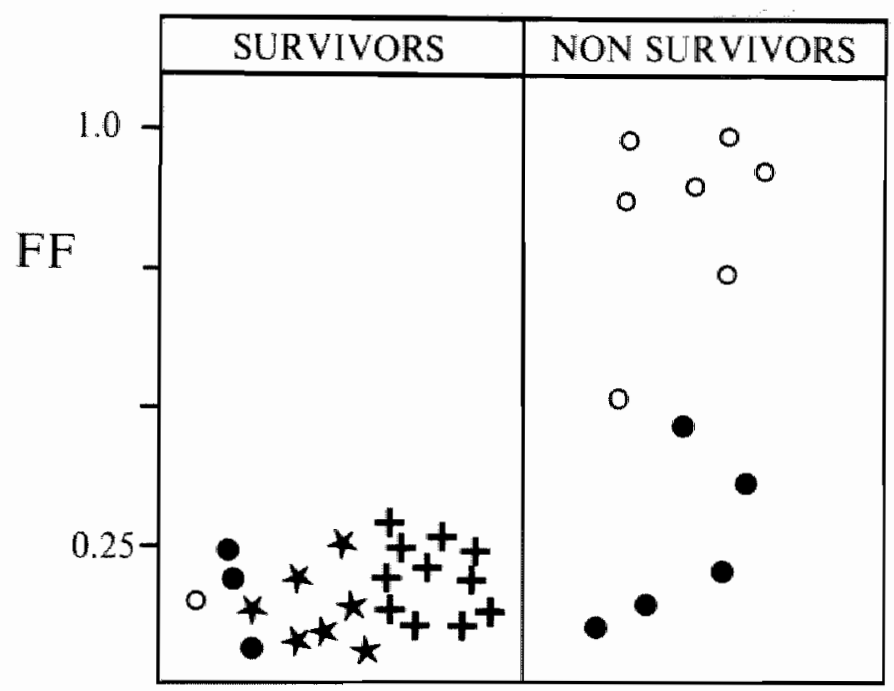

Figure VIII, 2: In group IV (modifled blood perfused; + ) all dogs had low flitration fractions at one hour after 1mplantation. For comparison the FF values of the other groups are also presented. (o:controls; *ex-v1vo perfused; : lsolated blood perfused in heart-lung machine with flim oxygenator). 
TaLLE VII, 2: FOLLOW-UP OF GLORERULAR FILTRATION RATE, EFEECTIVE RENAL PLASMA FLOW AND FILTRATION FRACTION IN SIX DASS PRESERVED BLOOD-PERFUSED KIDNEYS ARTER IMPLANTATTON. ${ }^{\mathrm{a}}$ (GROUP IV)

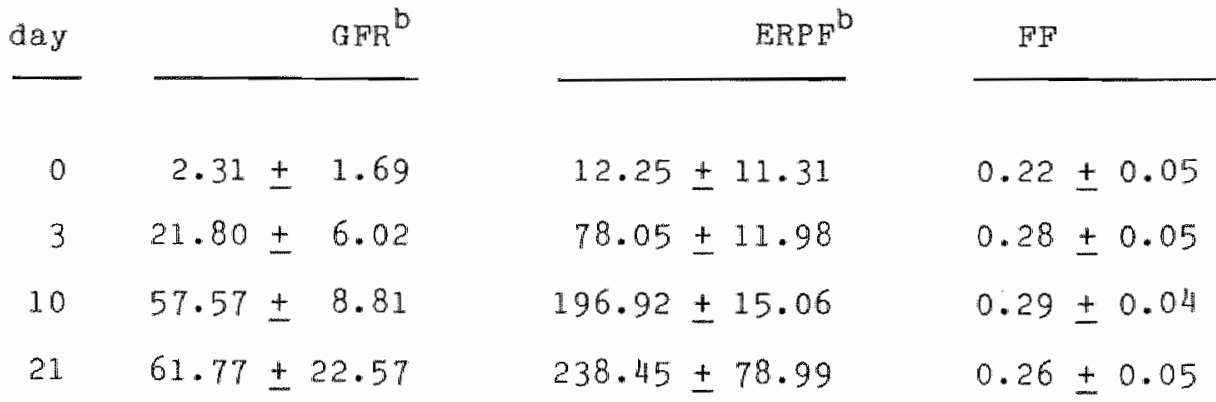

a Mean values \pm S.D. of flve dogs (no. 7-11) are presented.

b GFR and ERPF values are calculated in ml/min/100 g kidney we tght . 
(In flgure VIII, 2 the Fr values after implantation of ad1 cour experimental groups are summarlzed).

In flve dogs of group IV follow up cleatance deterinatons were performed at three, ten and 21 days after 1mplantation. The GFR and ERPF values returned to the $1 \mathrm{r}$ nomat ramge within ten days after implantation (Table VIII, 2).

Histology: In this group all dogs were sacrificed three weeks after implantation. Blopsies of these kldneys showed normal morphology. However, slgns of pyelonephritis were present to a certain amount in all kidneys due to ascending infection, which is inherent to the Implantation in the neok (168).

In this group two dogs had to be sacriflced for technical reasons at respectlvely three and seven days atter $1 \mathrm{~m}-$ plantation. Th1s offered the opportunity to compare thelr histology with that of the kldneys from group I and III whlch had no 11 fe-sustalning function. H1stologloal sectlons of these two kidneys showed normal glomerull and blood wessels. Signs of severe tubular damage were not seen in both kldneys; only a few casts were observed (FIg. VIII,3). On bisecting the kidneys at autopsy no haemorrhaglo zone was observed between the cortex and the medulla as opposed to the kldneys of group III.

Isolated blood perfusion: During the blood perfuslons the perfusion pressure was kept on 100 mm Hg. Inlt1a11y $1 n$ all kldneys a normal blood flow $(266 \pm 93 \mathrm{ml} / \mathrm{mLn} / 100 \mathrm{~g})$ was measured. After 20 minutes the renal blood flow decreased for about 30 minutes to Inorease finally to supranormal values $(411 \pm 68 \mathrm{ml} / \mathrm{min} / 100 \mathrm{~g})$ in the third hour of the perfusion $(\mathrm{FIg}$. VIII, 4$)$.

The decrease $1 \mathrm{n}$ blood flow during the first part of the blood perfusion was less severe than in the pllot atudies (FIg. VII,1). In this group the renal blood flow measured during the second part of the first hour was slgniflcantIy 


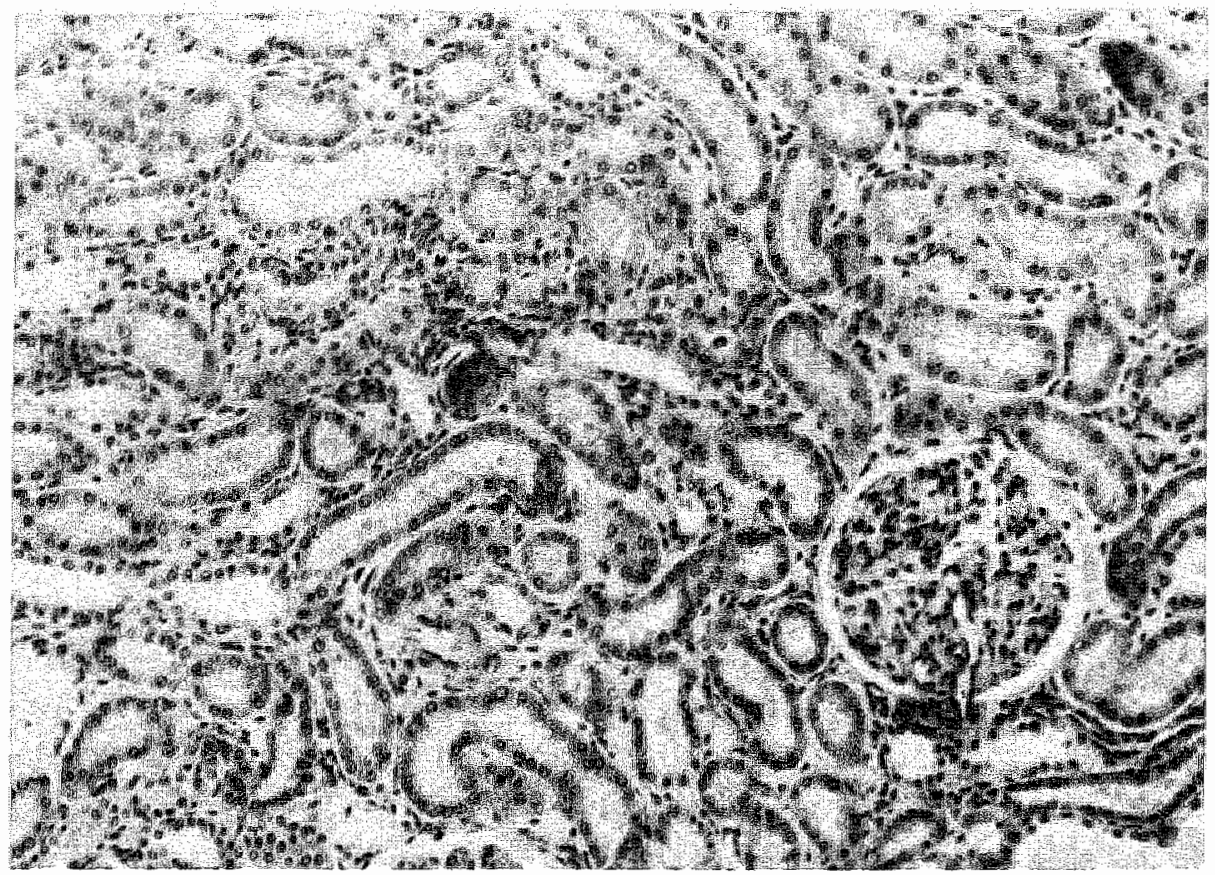

Flgure VIII,3: In group IV, two dogs had to be sacriflced for technlcal reasons at respectively 3 and 7 days after Implantation. This offered the opportunity to compare their histology with that of kidneys from group I and II which had no Iffe-sustalning Punction. Histology of these 2 kidneys showed normal glomerull and blood vessels. S1gns of severe tubular danage were not seen $\ln$ both kidneys; only a few casts were observed. (H1stology 3 days after 1 mpantation, ca. 250 x Hematoxi111n/Eosin). 
higher ( $p<0.05$ Wilcoxon test) than in $\mathrm{six}$ p1lot experiments with and without phenoxybenzamine. Durlng the blood perfusion different GFR and ERPF values were measured between the individual experiments. In each experiment the diuresis, Ger and ERPF decreased and Increased in proportion with the blood flow. No further increase of these parameters was abserved during the third hour of the perfusion (FIg. VIII, 4). As in other groups a low flitration fraction was measured; since the GFR and ERPF both followed the same pattern, the flitration fraction remalned unchanged throughout each Ind 1vidual perfusion.

During the last five minutes of the blood perfuslon the hyperosmolar manitol solution was added to the perfusate in the venous reservolr. This resulted in an abrupt increase in blood flow (20-30 $\mathrm{ml} / \mathrm{mln} / 100 \mathrm{~g}$ klaney) and urlne production (1-2 ml/min/100 g kidneg).

\section{Discussion:}

Finaliy, in this group (IV) the preservation time of dog kidneys could be extended successfully to six days by three hours blood perfusion in a modifled heart-lung machine halfway the hypothermic preservation perlod: nine out of 11 dogs survived in a healthy condition after implantation. Two dogs had to be sacriflced because of a technical fallure.

In this group the serum creatinine concentration levels after implantation were similar to or even lower than those reported by other authors after three days hypothermic continuous perfusion (70). The good function of the kidneys in group IV preserved by this comblned hypothermic and normothermic perfusion procedure was conflrmed by the normal aFR, ERPF and FF values measured ten days after implantation.

During the three hours 1solated blood perfusion the course of the GFR, ERPF and diuresis were influenced by the inttlal decrease in renal blood flow. As compared to the p1- 


\section{GROUP IV}

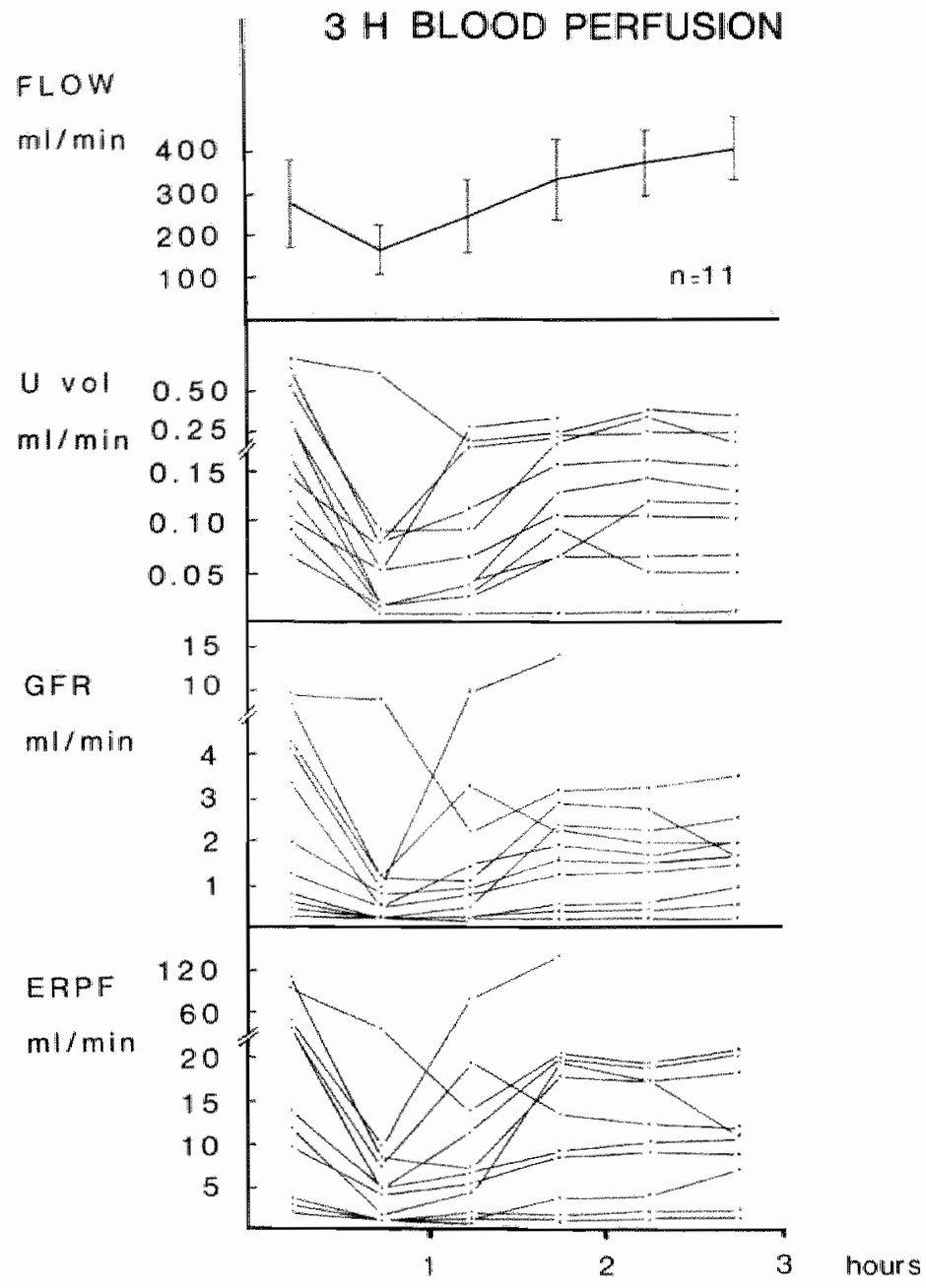

Flgure VIII, 4: Perfusion parameters of the blood perfusion halfway the six day preservation period in the group IV. The renal blood flow is presented in mean values $\pm S . D$. The urdne production, the glomerular filtration rate and the effectIve renal plasma flow are presented for each perfusion experiment. The flitration fraction showed no variation and was low throughout each perfusion (range 0.06-0.25. FF values are not presented in the figure). 
lot studies (FIg. VII, I) a better recovery of the GFR, ERPF and urine production was observed during the second hour", while these values cemalned stable durlng the third hour of the blood perfusion. The latter results obtained In this series experiments might be attributed to the improved blood flow conditions.

In comparison with the blood flow values in the pllot studies the blood flow decrease in this group was functionally antagonised by the addition of carbachol. The shorter and less severe vasoconstriction was considered of great importance to the recovery of the urine production, the GFR and ERPF (FIg. VIII,4). Evidence for this assertion was g1ven by Conger et al. (187) who studied the effects of norepinephrine induced vasoconstriction in rats. In confirmation with others $(188,189,190)$ they observed persistent low GFR values and ollgurla after restoration of renal blood flow by addition of acetylcholine. They measured high tubular pressures due to 1ntratubular obstruction, which was responsible for the marked reduction in glomerular filtration. With regard to these data 1t should be emphasized that the prevention of vasoconstriction is even more important in blood perfusion of preserved kidneys, since intratubular obstruction by "casts" is caused by prolonged hypothermic preservation itself (as shown in the histological sections of the control group) and by release of vasoconstrictive material by the kidney itself (Chapter IX).

Hyperosmolar mannitol solution was administered during the last five minutes of the isolated perfusion to counteract to some extent oedema which 1 s inherent to lsolated k1dney perfusion, as described in chapter $V$. It has been demonstrated by other investigators (185) that hyperosmolar mannitol induces decrease in renal vascular resistence in Ischaemic damaged kidneys by reducing tissue- and endothelial cell swelling. Indeed the infusion of hyperosmolar mannitol caused not only the expected osmotic diuresis but also an abrupt increase in renal blood flow during the last flve 
minutes of the blood perfusion. In this group the mannitol golution was given during the last minutes of the perfusion to avold possible detrimental effect on the kldney during prolonged perfusion. So a progressive dehydration of renal cells was prevented by short exposure to the hyperosmolar perfusate.

One hour after implantation all kldneys had low filtration fractions, indicating the presence of active functioning tubules. Histological examination of the kidneys or the two techndcal fallures in thls group reveales data whlch are comparable with the histology of non-viable kidneys of the control group and group III. In both kidneys normal glomeru11 and blood vessels were seen whthout any slgns of bleeding as In group III. These data suggest that vascular damage was prewented by the lower perfusion pressure (100 versus 120 mmHg) and the less complicated perfusion system applied in this group. In contrast with the control group few casts were obserwed in slices of both kidneys. This indlcates that the intermediate blood perfusion had a beneficlal effect especialiy on the tubular cells of the preserved kidney.

Fron the results presented in this chapter it can be concluded that irreversible damage induced by hypothermic preservation can be prevented by an artificlal normothermic blood perfusion. By this method the preservation time can be extended up to slx days without loss of viability of the klaney. The posstble mechanlsm of the beneflclal effect of the blood perfuston on the preserved kidney is discussed in chapter $x$. 


\section{FUSION}

In this chapter some remarks about the blood flow pattern during the normothermic blood perfusion are made. In the newly built perfusion apparatus, described in chapter VI, normal blood flow values were measured during perfusion of not-preserved kidneys (Table VI,1). In the course of the perfuston the blood flow increased steadily to supranomal values. This phenomenon, also described by others $(20,21)$ might be due to depletion of vasotonic agents, e.g. the loss of renin substrate from the blood perfusate (19).

on the other hand the vasodilation may be explained by activation of plasma kinins induced by activation of the Hageman factor by exposure to the forelgn surfaces of the perfuston apparatus. Evidence for the latter explanation of the vasodilation during the second part of the blood perfusion was given by Nizet et al. (12) who prevented the development of supranormal blood flow by addition of a soya bean trypsin inhlbitor (Trypsin like enzymes induce the formation of bradykinin). Bradykinin like substances also enhance the renal permeablilty leading to oedema. Hereby the decrease in GFR in proportion to the renal blood flow can be explained.

During the isolated blood perfusion of preserved kidneys in the pliot studies with the new heart-lung machine, a strongly different blood flow pattern was obserwed. A marked vasoconstriction was measured during the flrst part of the perfusion (Fig. VII,1). Impasped renal blood flow during the first hour of isolated kidney perfusion has also been described by other investigators $(17,20,21)$. According to Nizet et a1. (21) this vasoconstriction is caused by a vasoactive material released mainly by erythrocytes in the perfusate. It has also been suggested that the vasoconstriction might be caused by catacholamines released in the blood donor during bleeding. However, in two pliot studies the adaltion of the alpha adrenergic blocking agent, phenoxybenzamine (191), ratiled to el1- 
minate the vasoconstrletion (FIg. VII,1). In three pliot experiments the infuslon of hyperosmolar mannitol solution was effectlve in reducling the vasoconstriction (Flg. VII, I). It has been demonstrated by other investigators (185) that hyperosmolar mannteol Induces a decrease in renal vascular resistance In 1 gchaemic damaged kidneys, by reduclng tissue and endothe1 llal cell swelling. Johnston et al. (186) described that mannitol would also have a vasodilator effect in ischaemlc kidneys, mediated malnIy by increased prostacyciln (PGI,) activity. Although mannitol was effective in reducing the renal vascular resistance in the pliot experiments, 1 t seemed to have a detrlmental effect as well during prolonged perfusion in the heart-lung machine. This might be explained by a progressive dehydration of the kldney cells by the hyperosmolar perfusate.

Finally in the successfut series preservation experiments (group IV), the blood flow during the flest part of the blood perfusion could be Improved (FIg. VIII,4). As compared to the pliot experiments (FIg. VII,1) a significant (p<0.05, W11coxon test) reduction of the decrease in renal blood flow could be obtalned by the addition of carbachol. Elgure VIII, 4 shows that the vasoconstriction was not abol1shed but functionally antagonised. Bla1ne and Dunlay (192) measured vasodilatation after continuous infusion of acetylcholine in the renal artery. In the experiments of group IV satisfactory vasodilatation was brought about by a single dose of carbachol, which has a slmllar action on the vessel wall but which is broken down much less rapldiy.

Although the vasoconstriction in group IV was reduced, the blood fllow pattern st11 differed striklngly from the blood flow durlng the perfusion of not-preserved kldneys. As shown In Table VI, 1 the blood flow in these kianeys did not decrease during the first hour of the blood perfusion. This suggests that preserved kidneys are more susceptible to vasoconstricting agents clrculating in the perfusate. This might be due to elther the accumulation of vasoconstrictive factors that cannot be inactlvated rapldly enough by a preserved kldney, or by 
a release of vasoconstrletive material by the kidney toselt.

The blood flow difference between the not-preserved and the hypothermic perfused kldneys might be explained by the activation of the renin anglotensin system. Recently Derkx et al. (193) reported activation of (1nactuve) promenin by exposure to cold.

It is suggested that cold-promoted activation or prorenin occurred during the hypothermic perfusion of the kidney. At the start of the nomothemlc 1 solated blood perfusion the release of activated renin would cause the formation of anglotensin $I$ and subsequentiy angiotensin II, a potent vasoconstrictor. A typlcal finding was that the vasoconstriction in the preserved klaneys ocurred after 20 minutes. Mcalff and Itskovitz (194) reported the loss of vasoconstrictive activity of anglotensine II in 1schaemic kidneys. Supposing that the renin anglotensine system is involved in the vasoconstiction during the blood perfusion, these observations may explain why the blood flow alterations occurred just after 20 minutes. Further experiments $\mathrm{e} \cdot \mathrm{B}$. With the application of a converting enzyme Inhibltor (Captopri1), are necessary to eluclate these questions.

The proposed explanation makes 1 t difflcult to understand why the hypothermic perfused kidneys in group III did not show any vasoconstriction during the blood perfusion in the heartlung machlne with the flim oxygenator. In the pliot studies and $1 n$ group IV the only technlcal difference was the use of a membrane oxygenator instead of a flim oxygenator. However, 1 t is unlikely that this alteration could be responslbie for the vasoconstriction. On the contrary the mechanlcal damage of the blood in group IV, which would cause vasoconstriction, was less than in group III slnce macroseoplc haemolysis was not observed in group IV as opposed to group IIT. probably the stable blood flow in group III was due to the addition of promethazine. In prior studies by Nizet et al. (12) the action of promethazine on the blood flow in lsolated kidneys has been an emplrical flnding. Perhaps the antiserotonin (side) effectis of 
promethazine might explain why this antihistaminic arug prevented vasoconstriction in the heart-lung machine with the flimoxygenator. Promethazine was not added to blood perfusions in the heart-lung machlne with the membrane oxygenator. 
In this thesis the results of six day experimental k1dney preservation are described. Successful preservation was achieved by a combination of bypothermic continuous perfusion and three hours normothermic blood perfusion, elther "ex-vivo" or "1solated" in a heart-lung machine.

Successul experimental kidney preservation of three to four days by hypothermic continuous perfusion has been achleved by several investigators $(72,75)$ (Chapter I,3). However, consistent good results have not been reported after longer preservation periods $(69,75)$. In conformation with these data the results of the control group clearly showed that slx day hypothermic perfusion is not 11 kely to maintain the viablitty of a kidney: only one out of elght dogs survived.

It is suggested by several authors (195) that the nonviability of kidneys after prolonged hypothermic preservation is due to an impalrment of energy metabolism. After preservation, suppression of ATP regeneration upon revascularisation w11l cause loss of viability of the kidney, since Ilfe supporting functions require rapld resynthesis of ArP. Southard et al. (130) found in slices of hypothermic preserved dog kldneys loss of adenosine nucleotides, reduction in resplration and ATP synthesis, and uncoupling of oxldation and phosphorylation in the mitochondria. A progressive fall. In adenosine nucleotide content was also described by Buhl (196) In anaeroble perfused rabblt klineys: a complete regeneration of adenosine nucleotides was obtained during one hour in vitro perfusion with resumed oxygen supply and addition of adenosine (196).

These data might explasn the mechanism of the beneflctal effect of the blood perfusion on the preserved kidneys in the experiments described here. It 1s suggested that the metabollsm was restored during the blood perfusion. Indeed the low filtration fractions measured throughout each blood per- 
fusion indicated the presence of active energy metabolism in the proxlmal tubules. These data glve evidence for the restoration of ATP-levels in tubular cells during the blood perfusion. However, the content of adenosine nucleotides was not measured in this study. Determination of these biochemical parameters after the nomothermic blood perfusion would exolude the possibli1ty of testing the viabli1ty of the kidneys "In-vivo" at the end of the preservation period. Another semies of 1dentical experiments will be needed to find out whether the blood perfusion does restore the adenosine nucleotide content and ATP-synthesis.

At this polnt a recentiy developed method to test the viabli1ty of an organ may be mentioned. Chan et al. (197) were able to measure the ATP-content of human kidneys invivo by $3{ }^{I} \mathrm{P}$ nuclear magnetic resonance. This would enable the evaluation of the metabollc state of a preserved kidney with malntenance of the possibility to test the life-sustaining function of the organ "In-vivo". Certainly this might be a valuable method to obtain more information about the mechanlsm of the beneflclal effect of the normothermic blood perfusion in these preservation experlments.

Although the exact mechanlsm of the blood perfusion on the hypothermic preserved kldney remalns sofar unknown, the histologlcal data in group IV suggest a recovery of metabolism in tubular cells during the normothermic blood perfusion.

Explatining the mechanism of the blood perfusion in a slmplifled and tmivial way, one could say that the preserved kldney is "recharged like a battery", before 1t becomes exhausted completely. However, a more interesting comparison can be made with the behaviour of hibernating mamals (198). For Instance hibernating ground squirrels keep their body temperature at about $4-5^{\circ} \mathrm{C}$ during dormancy. Regardiess of amblent temperature or any other external stimulus, they wake up at seven to 12 days intervals. The anlmals rewarm rapldily from 4 to $36^{\circ} \mathrm{C}$ and exhibit full aclitity in eating, 
drinking and excretory behaviour before they peturn to tompld agaln (c. Green, personal communlation). The resemblanee with this natural existing behavloum of hibernating mammals lndicates that the kloney preservation model described here may be a logical approach to $10 n g-t e m$ omgan preservation.

\section{Conclusion}

From this study 1 t can be concluded that it is possible to prevent irreversible preservation damage in hypothermic continuous perfusion by three hours nomothermic lsolated blood perfusion, after whlch the organ can be preserved for another three days. The data suggest that by further lmprovement of renal blood flow during the flrst part of the blood perfusion, the beneflclal effect can be obtained by a shorter perfusion period. Moreover this would limit the detrimental effects whlch are inherent to prolonged lsolated blood perfusion of kidneys.

In addition further lmprovement of penal blood flow would make this preservation model suitable for wiablitty monitoring of hypothermic preserved kidneys. Furthermore, if the same results can be obtalned by using an artiflcial perrusate, it would be possible to use the model to find out which factors are responsible for the beneflolal effect of the nomothermic intermediate perfusion. This might also contribute to the development of improved bypothermic preservation techniques.

Flnally, the good results of these six day preservation experlments suggest that the application of alternating hypothernic and normothemic perfusion might enable long-term preservation In the future. 
In this thesis a new kidney preservation method is described. Successful six day preservation of dog kidneys was achleved by hypothermic albumin perfusion comblned with a short intermediate normothermic blood perfusion.

In chapter I a review $1 \mathrm{~s}$ presented of the development and current status of varlous kidney preservation methods employed in the clinical and experimental situation: Preservation by normothermia is not sultable for transplantation surgery, although normothermic perfusion may be applied to assess the viablitty of a kldney before transplantation.

Next several flush solutions for cold storage preservation are discussed. Most of these solutions can be safely used up to 36 hours for kidney preservation. The effect of these preservation solutions is explained as follows: during hypothermic preservation osmotic cell swelling is caused by the decreased activity of the $\mathrm{Na} / \mathrm{K}$ pump in cell membranes. The efficlacy of the preservation solutions is due to the presence of Impermeable anlons and to the high osmolarity and not to the "Intracellular" composition as stated formerly. The cold storage technique is less effective for preservation of kidneys which have suffered a considerable warm ischaemic time (non heartbeating donors). In these clrcumstances hypothermic continuous perfusion is preferable. Clinlcal and experimental data indicate that kldney preservation up to 72 hours can be obtained wlth hypothermic perfusion. The compostition of several perfusates is discussed.

Kidney preservation by freezing has not been achleved as yet. On the other hand cryopreservation of cell suspensions and embryos can be performed without unacceptable loss of vlability. Probably the characteristics in which organs distingulsh from cell suspensions, namely the flxed geometry, the high density of various celis and a vascular system, are malinly responsible for the disappolnting results sofar ob- 
talned in cryopreservation of organs.

Kidney preservation by comblned hypothermic perfusion and cold storage does not result in prolonged preservation time. Klaneys preserved by intermittent cold storage and hypothermic perfuston would be less viable than kldneys preserved by one of these techniques alone for the came time.

In this thesis the results of combined hypothermic and nomothermic perfusion are described. The study is a continuation of the research performed by kootstra and van der Wijk. They have shown that the preservation time of dog kidneys could be prolonged by a comblnation of hypothermlc and normothermio perfusion. Halfwa a hypothermlc and normotherinlc perfusion period of 4 to 6 days with an albumin perfusate the preserved kldney was connected with the clrculation of the donor dog. After several hours normothermic perfusion the hypothermic preservation was continued with the same albumin perfusate. Normothermic, so-called "ex-v1vo" perfusion resulted in a significantly better kidney function after autotransplantation and immediate contralateral nephrectomy.

In chapter II the materials and methods applied in the preservation experiments are described.

The experiments described in chapter III clearly show that a six day period of hypothermic perfusion only is not likely to malntain the viablilty of a kidney. In the control group (I) only one out of elght dogs survived after tmplantation.

The experiments discussed in chapter IV Indicate that successful kidney preservation can be obtalnea by combunation of hypothermic preservation and normothermic ex-vivo perfusion of three hours. In a consecutive serles of seven experiments all animals survived with good kidney function (group II). During the three hour ex-vivo perfusion an increase in glomerular flitration and tubular secretion was measured. Although a preservation time of $s 1 x$ days was 
reached, there was no question of true preservation 1 in group II suce the kineys were connected agaln with the donordog. In the next experments an atempt was made to obtaln sind a results by replacement of the ex-vivo perfuston by an artiflelal perfusion in a heat-1ung machine.

In elfit experiments described in chapter $V$ the nomotherme perfusion was performed in a heart-1ung machine lncluding a film oxygenator and a hydraulic balioon-pump. Freah heparlnised blood was used as perfusate. Successtul $81 x$ day preservation was obtalned in only three out of elght experiments (group III). Klaney function measured at one nour after Implantation Indicated that most kidneys did have active functionling tubules. The poor results in this serles can be explained by endothellal damage which might be due to the high perfusion pressure during the blood perfusion. Ev1dence for this explanation 1 s glven by numerous haemorrhagic areas whlch were observed both macroscopleally and microscopleally at autopsy.

Chapter VI describes the construction of a modifled heart-lung machine especlaling adapted to the requirements of the perfusion of a preserved kidney.

In chapter WI some pllot experlments are described in which the modifled heart-lung machine was used in the $s 1 x$ day preservation model. In these experlments an attempt was made to lmprove the renall blood flow during the heart-lung perfusion. By addition of carbachol and - at the end of the parusion - manntol, improvenent of the results was obtalned.

Tn a consecutive seres of 11 experiments, described in chapter VIII, successful six day kidney preservation was achleved by three houm nomothemic blood perfusion in the modlfled heart-lung machine (sroup IV).

In chapter IX speclal attention is paid to the blood flow pattem durling the nomothemic perfusion ln the different preservation experiments. 
Finally, In chapter $x$ the mechandsm of the beneflclal effect of the normothermic blood perfusion is discussed. It is suggested that the energy metabolism in the cells is restored during the normothermic perfusion. The blood perfusion resulted in a better preserwation of the tubules as shown by histological examination in group IV.

From this study can be concluded that it is possible to prevent 1 rreversible preservation damage in hypothermic continuous perfusion by three hours normothermic tsolated blood perfusion, after whlch the organ can be preserved for another three days. Further improvement of the renal blood flow durling the normothermic perfusion would make this preservation model sultable for viablitty montoring of hypothermlc preserved kianeys. Finally, the good results of these six day preservation experiments suggest that application of alternating hypothermic and nomothermlc perfusion might enable long-term preservation in the future. 
In dit proefschrift word een nieuwe nierpreservatie methode beschreven. Succesvolle zesdaagse preservatie van hondenleren werd verkregen door middel van hypotherme perfusle met albumine gecomblneerd met een korte tussentijdse normotherme bloedperfusie.

Hoofdstuk I geeft een overzicht van de ontwlkkeling en huldige toepassing van versch1liende nierpreservatie methoden in de klinische en experimentele situatie. Preservatie net behulp van alleen normotherme perfusie 1s niet geschlkt voor transplantatie chirurgle, ofschoon normotherme perfusle kan worden toegepast om de vitalitelt van een nier te beoordelen voorafgaande aan transplantatie. Vervolgens wordt de samensteling van verschillende preservatie vioelstoffen besproken die gebrulkt worden voor de zgn. "cold storage" preservatie. De meeste van deze vloelstoffen kunnen vellig gebrulkt worden voor nierpreservatie tot 36 uur. De werking van deze preservatie vioelstoffen wordt als volgt verklaard: tifdens hypotherme preservatie veroorzalkt de afgenomen activitelt van de $\mathrm{Na} / \mathrm{K}$ pomp in de cel membraan osmotische zwelling van de cel. De werking van de preservatie vioeistofien berust op de aanwezigheld wan impermeabele anionen en de hoge osmolaritelt, en nlet, zoals vroeger werd beweerd, op de "Intracellulalre" lonen samenstelling.

De "cold storage" techniek 1.5 minder effectief voor het preserveren van nleren die een aanzlenlifk lange wame ischaemle tifd hebben ondergaan (bv. hart-dode donoren). In deze onstandigheden verdient hypotherme continue perfusie de voorkeur. Klinlsche en experimentele gegevens wijzen erop dat nlerpreservatie tot 72 uur kan worden berelkt met behulp van hypotherme perfusle. De samenstelling van diverse perfusaatvloeistoffen wordt besproker.

Nlerpreservatie door middel van invriezen is tot nu toe nog nlet gelukt. Daarentegen kan cryopreservatie van celsuspensies en embryo's worden verrlcht zonder inacceptabel 
vitalitelts verlies. Waarschijnlijk zijn voomamelijk de eigenschappen waarin hele organen verschllien van cel-suspensies, te weten de vastliggende geometrische verhoudingen, de hoge dichtheid van verschiliende celien en een vatstelsel, verantwordelijk voor de teleurstellende pesultaten die tot dusver zijn behald met het invrlezen van organen.

Door een combinatie van hypotherme perfusle met "cold storage" kan de duur van de nierpreservatie nlet worden verlengd. Nieren die afwlsselend met "cold storage" en hypotherme perfusle worden gepreserveerd zouden minder vital1telt behouden dan nieren die even lang bewaard worden met één van de methoden afzonderlijk.

In dit proefschrift worden de resultaten van gecombineerde hypotherme en normotherme perfusie beschreven. Het onderzoek is een voortzetting van experimenteel werk verrleht door Kootstra en van der Wijk. In dierexperimenten toonden zif aan dat de preservatieduur van hondenieren kon worden verlengd door een combinatle van hypotherme en normotherme perfusie. Halverwege een hypotherme perfusie periode van 4 à 6 dagen met een albumlne oplossing werd de gepreserveerde nier aangesloten op de lichaamscliculatie van de donorhond. Na enkele uren normotherme perfusie werd de hypotherme preservatie voortgezet met hetzelfde albumine perfusaat. De normotherme zgn. "ex-vivo" perfusie leldde tot een signiflcant betere nierfunctie na autotransplantatle en direkte contralaterale nefrectomie.

In hoofdstuk II worden de materialen en methoden beschreven welke werden toegepast bif de preservatie experdmenten.

U1t de experimenten beschreven in hoofdstuk III bl1fkt dat een zesdaagse preservatie perlode met alleen hypotherme perfusie resulteert in een irreversibel furktieverlies van de nier. In deze controle groep (I) overleefde slechts één van de acht honden na limplantatie.

De experimenten besproken in hoofdstuk IV tonen aan dat succesvolle zesdaagse nierpreservatie kan worden berelkt 
door de hypotherme preservatie te conblneren met een drie wur durende nomotheme ex-vivo perfusie. In weven opeenvolsende experimenten overieefden ada proefdieren met een boede nierfunkte (groep II). Thjens de drie uur durende ex-vivo peritule werd een verbetering van de glomerulaire Plitatie en de tubulus secretle gemeten. Bij deze experimenten was geen sprake van echte preservatie, aangezen de nler tifdelifk werd verbonden met de donorhond. In de volgende expermenten werd getracht dergelike resultaten te berelken door de ex-yvo perfusle te vervangen door kunstmatige perfusie in een hartiong machine.

In hoofdstuk $v$ worden acht expermenten beschreven waarbly de normotherme periusle werd uitgevoerd in een hart-1ong machlne met een flim-axygenator en een hydraulische ballonpomp. Als perfusaat werd vers heparine bloed gebrulkt. Van de acht experimenten werd in slechts drie gevallen succesvolle zesdaagse preservatie verkregen (groep III). De nier.. funktle gemeten éen uur na 1 mplantatle wees erop dat bly de meeste niemen wel actief secernepende tubull aanwezig waren. De slechte resultaten in deze serle kunnen worden verklaard door endotheel beschadiglng ale zou zijn ontstaan door een hoge perfusle druk tijdens de bloedpertusle. Deze verklarlng Is aammemelijk door de vele haemorkhagische gebleden, welke zowel macroscopisch als microscoplsch warneembare waren blj obductle.

In hoofdstuk VI wordt de constructle beschreven van een gewljzlgde hart-long machlne, dle speclaal wera aangepast an de elser besteld an de perrusle van eer gepreserveerde nier.

In hoofdstuk VII worden enkele pilot experimenten beschreven warbly de gewldzlgde hart-long machlne werd Bebrulkt in het zesadagse nierpreservatle model. In deze serie experimenten werd getracht de bloedflow door de nier tajdens de hartlong perfusle te verbeteren. Door toevoeglng van carbachol en - aan het elnd van de perfusle - mannltol werd verbetering van de resultatem bereld. 
In een serie var 11 opeenvolgende experimenten besohreven in hoofdstuk VIII, werd succesvolie zesdagise nierpreservatie verkregen met behulp van drle uur nomotherme bloedperfuste in de gewljzlgde hart-long machlne (groep IV).

In hoofdstuk IX wordt speclale aandacht besteed aan het verloop van de bloedrlow tijdens de nomotherme perfusle in de verschillende preservatie experimenten.

Tensiotte wordt in hoofdstuk $x$ het mechanlsme van het gunstlg effect van de normotherme bloedperfusie besproken. Gesuggereerd wordt dat het energle metabolisme in de cel zich herstelt tijdens de nomotheme perfusle. De bloedpertusle resulteerde met name in een betere preservatie van de tubuli, hetgeen werd aangetoond door histologisch onderaok in groep IV.

De conclusie van dit proefschrlft luldt dat het mogelljk is lrreverstbele preservatie schade ten gevolge van hypotherme perfusile te voorkomen door een drle uur durende ge1soleerde nomotherme bloedperfusie; de nler kan Mierna nog eens drie dagen worden gepreserveerd. Verdere verbetering van de bloedflow tijdens de normotherme perfusle zou dit preservatiemodel geschikt kunnen maken voor het bepalen van de vitaliteit van een hypotherm gepreserveerde niler.

Tenslotte suggereren de goede resultaten van deze zesdaagse preservatie experimenten dat in de toekomst de toepassing van afwisselend hypotherme en nomotherme perfusie langdurige nlerpreservatie mogelljk makt. 
1. Herodotus. Histomes, book II. In "Herodotus" with an english translation by A.D. Codley. Vol. I, D. 371. Harvard Unlversity Press, Carbridge, Massachusetts, and W111Lam Helnemann, London, 1966.

2. Starling EH, Wemey EB: The secretion of urine as studied in the 1solated kidney. Proc R Soc Biol (B101) 97: 321-363, 1925.

3. Brodle TIO. Perfuston of surviving organs. J Physiol (Lond) 29: 266, 1903.

4. Knowlton FP and Starling FG. The Influence of varations in temperature and blood pressure on the perfomance of the 1solated mamalian heart. I Phys'101 (Lond) 44: 206, 1912.

5. Bainbridge FA and Evans CL. The heart, Iung and kidney preparation. J Phys 1ol (Lond) 48: $278,1914$.

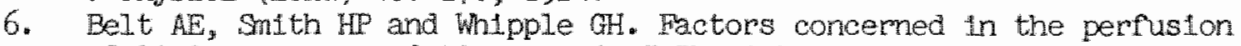
of living organs and tissues. Arm J Phystol 52: 101, 1920.

7. Henlngway A. Some observations on the perfusion of the 1solated kidney by a pump. I Physiol (Lond) $71: 201-213,1931$.

8. Brull L and Louls-Bar D. Toxlcity of artiflc1ally clrculated hepar1nised blood on the kidney. Arch Int Physlol Blochem 65: 470-476, 1957.

9. N1zet $A$, Cuypers $Y$, Massillon $L$ and Lambert $S$. Mise en évidence de facteurs rédulsant le débit sanguin rénal et libéré par les hématles. Arch Int Physiol Blochem 65: 568-588, 1957.

10. Cuypers $Y$, Korver $G$ and Nizet A. Neutralisation par différents arganes de l'action vasoconstrictice du sang hépariné et conservé. Arch Int Physlol Blochem 69: 213-221, 1961.

11. Cuypers $Y$, N1zet $A$ and Baerten A. Technique pour la perfusion de relns Isolés de chien avec du sang hëparinë. Arch Int Physiol BLochem 72: 245-255, 1964 .

12. Nizet $A$, Cuypers $Y$, Deet Jen $P$ and Kramer $K$. Functional capacity of the isolated perfused dog kianey. Pflugers Archlv 296: 179-195, 1967.

13. Dale HH and Schuster EHJ. A double perfuslon-pump. J Physiol 64 : 356-364, 1928.

14. Schröder E, Ochwadt B and Bethge H. Herstellung und Funktion eines Isollerten Nlemenpraparates vom Hund. Pflugers Archtves 286: 189$198,1965$.

15. Schepper J de, Stock J van der. Fen perfuste methode van de geIsoleerde hondenier. Maams Diengeneeskundig TIJdschrift 40: 373, 1971 .

16. Kulat1lake $\mathrm{AE}$. Isolated perfuston of canine and human kidneys. Br $\mathrm{J}$ Surg $54: 877-882,1967$.

17. Rasenfeld $S_{3}$ Sellers AL and Katz J. Development of an 1solated perfused marmallan kidney. Am J Phys1ol 196: 1155-1159, 1959.

18. Rosenfeld $S$, Kraus $R$ and McCullen $A$. Effect of rent $n$, Ischemla and plasma protein loading on the 1solated perfused kidney. Am J Physiol 209: 835-843, 1965.

19. Berkowt.tz HD, Miller LD and Itskowltz HD. Renal function and the renln-anglotensin system in the 1solated perfused kldney. Am J Physlol 213: 928-934, 1967.

20. Waugh WH and Kubo T. Development of an 1solated perfused dog kidney with limproved function. Am J Phys1ol 217: 277-290, 1969. 
21. Nizet A. The isolated perfused kidney: Possiblilties, IImlations and results. Ed. review. Kloney Int $7: 1-11,1975$.

22. Gagnon JA, Grove DW and Wlamenbaum W. Blood flow distribution and tissue solute content of the isolated perfused kdaney. Prilugens Archlv 347: $261-274,1967$.

23. Behlmann J, GiebIsch G, Ochwadt B and Schoeppe W. Micropuncture study of isolated perfused rat kidney. Am J Physliol 212: 77-82, 1967.

24. Ross $\mathrm{BD}$, Epstein $\mathrm{FH}$ and Ieaf $\mathrm{A}$. Sodium reabsorption in the perfused rat kidney. Am J Physiol 225: 1165-1171, 1973.

25. Fuller BJ, Pegg DE, Walther $C A$ and Green $C$. An isolated rabblt kidney preparation for use in ongan preservation research. J Surg Res 22: 128-142, 1977.

26. Kowallewski $\mathrm{K}$ and Kalodej A. Secretory function of 1 solated cantne pancreas perfused with fluorocarbon emulsion. Surg gymecol obstet 146: $375-378,1978$.

27. Kowalewsk1 K, Kolodej $A$ and Kocylowski A. Secretion of Insulin by the canine pancreas perfused ex vivo with fluorocarbon enulston. Surg Gynecol Obstet 148: 539-542, 1979.

28. Indrich B, Greenburg AG, Intaglietta $M$ and Peskin G. Flluorocarbon emulsions as blood replacement fluid: Influence on the omental microcirculation. J Surg Res 26: 185-198, 1979.

29. Endrich B, Newman $M$, Greenburg $A G$ and Intagl1etta M. Fluorocarbon emulsions as a synthetic blood substitute: Effects on microvascular hemodynamics in the rabb1t onentum. J Surg Res 29: 516-526, 1980.

30. Dumn PN, Merkel FK, Roseman D, Haklin M and Mnglish K. Is normothermic preservation an alternative to hypothermic preservation? Organ Preservation: Basic and applled aspects (Ed. DE PegB, IA Jacobsen and NA Halasi) Lancaster: MIP press, 1982: p. 273.

31. Schrler JF, Rudowskd WJ, Daszynski J, Goralski SA and Helczyńsk1 L. Influence of strona-free hemoglobin solution on renal function in dogs. Z Exper Ch1mang 12: 138-145, 1979.

32. Suaudeau J, Fallon JT, Austen WG and Erdmann AJ. Protection by plasma protelns of the isolated lamb heart perfused with stroma-free hemoglobin at $38^{\circ} \mathrm{C}$. Am Surg 189: 322-333, 1979.

33. Cassie $G$, Couch $N$, Dammin $G$ and Murray JC. Normothermic perfusion and relmplantation of the excised dog kidney. Surg Gynecol Obstet 109: $721,1959$.

34. Funler BT and Pegg DE. The assessment of renal preservation by normothermic bloodless perfuston. Cryoblology 13: 177-184, 1976.

35. Whisteman MC. 'The effect of warm ischemia on the function of rebblt ktdneys measured by isolated nomothemlc perfusion. I Surg Res $23:$ $332-338,1977$.

36. Marshali V, Ross B, Blishop M and Morrls P. Evalulution of renal preservation usirg the 1solated perfused rat k1dney. Transplantation 26: $315-318,1978$.

37. Murray JE, Merril JP, Harrison JH, WLIson RE and Damin GJ. Prolonged survival of muman-kidney homografts by immunosuppressive drug therapy. N Engl J Med 268: 1315-1323, 1963.

38. Lefebre $L$ and Nizet $A$. Shunt vasculalre dans les relins de chien perfusés et conservés a basse température. Arch Int Phamacodyn 92: $119,1952$.

39. Levy MV. Oxygen consumption and blood flow in the hypothermic perfused kidney. An J Phystol 197: 1111-1114, 1959. 
40. Caine RY, Pegg DF, Pryse-Davis J and Lelgh-Brown F. Renal preservation by loe-coollng. Ar experimental stidy relating to kidney transplantation fron cadavers. Br Med J $2: 651-655,1963$.

41. Pegs DE An approach to hypothemic renal preservation. Cryoblology $15 * 1-17,1978$.

42. RHer JC, Melander R, Peterson TA, Coe J and H1tohoock CR. Canine renal aliografts. Studies of reversible histopathologic changes following prolonged extracorporeal refrigeration. Arch Surg 83: 502511, 1961 .

43. Bruntus V, Bergentz BE, Ekman $\mathbb{H}$, Melin LE and Westberg $\mathrm{C}$. The cadaveric letaney in clinlcal transplantation. Scand J Urol Nephrol 2: $15-23,1968$.

44. Keeier R, Swinney $:$, Taylor RM and ULdal.1 MB. The problem of renal. presemation. Br J Urol 38: 653-655, 1966.

45. Collins GM, Bravo-Shugeman M and Terasales PI. Kidney preservation for transportation. Lancet ?: 1219-1222, 1969.

45. Hartley ICJ, Collins GM and Gunie GJA. KLaney preservation for transpoptation. Function of 29 human-cadaver kidneys presemed with an Intracellular perfusate. N Engl J Med 285: 1049-1052, 1971.

47. Collins GM and Halasz NA. Forty-elght hour ice storage of kidney. Importance of cation content. Surgery $79: 432-435,1976$.

48. Braf ZVI. F and Bolchis H. Toxic1ty of Collins" solution. Lancet 1: $563,1974$.

49. Collins GM, Hartley ICJ and Clunle GJA. Kidney preservation for transportation: Experimental analysis of optinal perfusate composition. $\mathrm{Br}$ J Surg 59: 187-189, 1972.

50. Collins GM, Green RD and Halasz NA. Importance of anion content and osmolarlty in Push solutions for 48 to 72 hour hypothemfo bidney storage. Cryoblology 16: 217-220, 1979.

51. Watk1ns GM, Prentiss NA and Couch NP. Successful 24-hour kidney preservation with simplifled hyperosmolar hyperkalemic perfusate. Transplant Proc 3: 612, 1971.

52. M111ez $\mathrm{P}$ et al. Influence of 1schaenta on post-transplant Nunction of 188 cadaver renal grafts. Lancet $2: 887,1972$.

53. Jensen W. Preservation of rabblt kidneys without perfuslon. The slignifleance of the $\mathrm{Na}^{+} / \mathrm{K}^{+}$rat1o, the phosphate concentration and the dextrose concentration in the wash out fluld. Organ Preservation (Ed. DE Pegs) Church111-L1vingstone, London and Edinburgh, $p .7$. 1973.

54. R1jksen JIWB. Compos1tion of the Duro-Collins' solution. Eurotransplant manual. Eurotransplant Foundation, Unlversity Hospltal, Le1den, Holland, p. 30, 1972.

55. Sacks SA, Petritsoh PH and Kaufman JJ. Canine kidney preservation. using a new perfusate. Lancet 1: 1023-1028, 1973.

56. Johnson PWG. The effect of 1schaemic Infury on kidneys preserved for 24 hours before transplantation. Br J Surg 59: 765, 1972.

57. MoCabe $\mathrm{R}$, Applebaum H, Lorleo $D$ and Stevens L. Fallure of cantne kldney preservation using Sacks II solution. Lancet I: $517,1975$.

58. Chatterjee SN, Berne IV. Fallure of 48 hours of cold storage of canine kldneys using Sacks' solution. Transplantation 19: 441, 1975.

59. Ross H, Marwhall VC and Escott ML. 72-hour canine kidney preservation without continuous perfusion. Transplantation 21: 498-501, 1976. 
60. Guthinger WP, Linke ChA, Pranikoff $K$ and Fridd ChW. Compartson of hypertonlc citrate and Collins $\mathrm{C} 2$ and 03 flushling solutions in cantne cold storage kidney preservation. Transplantation 25: 279, 1978.

61. V1 $D$, Chee M and Toledo-Pereyra LH. Fallure of hypertontc citrate solution to preserve canine renal transplants after 24 hours of hypothermic storage. Transplantation 29: 90, 1980.

62. Toledo-Pereyra IH and Condle RM. Conparison of Sacks and a new colIold hyperosmolar solution for hypothermic renal storage. Transplantation 26: $166,1978$.

63. Burg MB and Orloff J. Active catlon transport by kidney tubules at $0^{\circ} \mathrm{C}$. Am J Physiol 207: 983-988, 1964.

64. Jambotte $I$. Persistance of active and passive lonilo transport dur.Ing Iow-temperature Iiver preservation. Surgery 73: 8-14, 1973 .

65. Humphries AL, Russell R, Ostafin J, Goodrich SM and Moretz WH. Successful relmplantation of canine kidney after 24 hour storage. Surgery 54: 136-143, 1963.

66. Humphries AL, Moretz WH and Pelrce EC. Twenty-four hour kidney storage with report of a successful canine autotransplant after total nephrectomy. Surgery 55: 524-530, 1964 .

67. Humphrles AL, Russell $R$, Stoddard LD and Moretz WH. Three-day kidney preservation: Perfusion of kidneys with hypothemic diluted blood or plasma. Surgery 63: 646-652, 1968.

68. Belzer 70 , Ashby BS and Dunphy, JE. 24-Hour and 72-hour preservation of candne kidneys. Lancet 2: 536-539, 1967.

69. Woods JE. Successful three-to-seven day preservation of cantine ktaneys. Arch Surg 102: 614-616, 1971.

70. Abouna GM, LAm F, Cook JS, Grubb W, Cralg SS, Selbel HR and Hume DM. Three-day canine ktdney preservation. Surgery 71: 436, 1972.

71. Preuss HO and Murdaugh HV. The toxic effect of ammonia on renal cortical tubule function in vitro. J Lab \& Clin Med 71: 561-572, 1968.

72. Grundmann R, Berr F, PItsch $H$, Kirchhof $R$ and Plohelmaler H. Ninety-six-hour preservation of canlne kidneys. Tramsplantation 17: 299$305,1974$.

73. Wliliams JT, Hoffman $\mathrm{R}$ and Belzer Fo. Lack of correlation between pertodic perfusate changes and subsequent renal function. Transplantation 15: 629-630, 1973 .

74. Johnson RWG, Anderson M, Flear CTG, Murray SGF, Taylor RMR and SwInney J. Evaluation of a new perfusion solution for kldney preservation. Transplantation 13: 270-275, 1972.

75. Johnson KWG, Cohen GL and Balliardle FD. The $1.1 \mathrm{~m} 1$ tations of cont 1 nuous perfusion with plasma protein fraction. Organ Preservation II (Ed. DE Pegg and IA Jacobsen), Church111-Livingstone, Sdinburgh, London and New York, p. 18, 1979.

76. Claes $G$ and Blohmé I. Clinical experience with albumln perfuston of human kldneys. Organ Preservation (Ed. DE Pegg), Churchill-Livingstone, Iondon and Falnburgh, p. 60, 1973.

77. Cohen GL, BallardLe FW, Malnwaring A and Johnson RWG. Lysosomal enzyme release durlng successful 5,7 and 8 day cantne kldney storage. zyme release during Busic and applied aspects (EA. DE Pegg, IA Jacobsen and NA Halasz), Iancaster, MPP press, p. $249,1982$.

78. Abouna GM, Pashley DH, Ginsbury JM, Delong TG, Sobel REE and Jeske AH. KIdney preservation by hypothermic perfuston with atbumin versus plasina and with pulsatile versus non-pulsatile flow. Br J Surg 61: $555-561,1974$. 
79. Toledo-Pereyra LH, Condle RM, Nalmberg, R, Simons RL and Najartan JS. A flbrinogen-free plasma perfusate for preservation of kidneys for one hundred ard twenty hours. Surg aynecol Obstet 138: 901-905, 1974.

80. Belzer FO, Ashby BS, Gulyassy PF and Powell M. SuccessfuI seventeen-hour preservation and transplantation of human-cadaver kidney. $N$ Engl J Med 278: 608-610, 1968.

81. Belzer Fo. Renal preservation by continuous hypothermic perfusion past, present and future. Transplant Proc IX: 3: 1543, 1977.

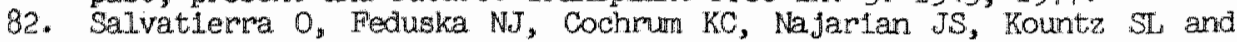
Belzer Fo. The impact of 1000 renal transplants at one center. Arn Burg 186: $424-435,1977$.

83. Feduska NJ, Belzer Fo, Stieper KW, Duca FM, MHtchell JW, Vincenti F, Cochmu KC and Salvatierra O. A ten year experlence wlth cadaver kIdney preservation using cryoprecipltated plasma. Am J Surg 135: $356-361,1976$.

84. Garvin PJ, Codd JE, Newton WI and W17lman VL. Perfusate composition In renal preservation. Arch Surg 112: 67, 1977.

85. McCabe $R$, Plerce JC, Lattes $C$, Lorieo $D$, Hardy $M$, Jean-Jacques $M$, Cuttis $A$ and Fitzpatrick H. Reduction of acute tubular necrosis by continuous pulsatile perfusion with plasma protein fraction. Transplant Proc IX, 3: 1547, 1977.

86. Burleson RU, Jones DB, Yenjkonshian AM, Cornwall C, DeVoe Ch and DeRito J. Cilnical renal preservation by cryoperfusion with an albumin perfusate. Arch Surg 113: 688-692, 1978.

87. Horpacsy G, Scholz D, AIthaus $P$ andP $<$ May M. Clinical experiences in the Gambro-preservation unlt: Analyses of 101 human cadaver kidneys. Eur surg Res 11: 50-60, 1979.

88. Belzer FO, Hoffmann FM, Miller DT, Glass NR, Sollinger HW and Southard J.. A new perfusate for kidney preservation. Transplant Proc 16: 161,1984 .

89. Moberg AW, Santiago EA, Mason RV, Mozes MG, Campos RA and Najarian JS. Transportable organ-perfusion system for kidney preservation. Lancet 2: 1403-1405, 1971 .

90. Sullivan MJ, Palmer M, Swenson DA and Kayfetz L. Cadaver kidney preservation with viacell organ perfuston apparatus. Arch Surg 111: 1103-1105, 1976.

91. Opelz $a$ and Terasak1 PI. Decreased transplant surv1val rate of shared and nonshared machlne-preserved cadaver kldneys. Transplant Proc IX, 3: 1505-1512, 1977 .

92. Belzer FO. Evaluation of kidney-preservation methods. Lancet 2: $1063-1064,1973$.

93. Milier HC, Alexander JW and Sint th FJ. Evaluation of Kidney preservation methods. Lancet $1: 880-881,1973$.

94. Toledo-Pereyra LH, SLmons RL, Moberg AW, Buselmeler TJ, KJellstrand CM and Najarlan JS. Effect of ongan preservation in cadaver ktdney transplantation. Kidney Int 8:132, 1975.

95. Scott DF, Wh1teside D, Redhead $J$ and Atkins RC. Ice storage versus perfusion for preservation of kidneys before transplantation. $\mathrm{Br}$ Med J $4: 76,1974$.

96. Opelz $\mathrm{G}$ and Terasakt PI. Advantiage of cold storage over machine perfusion for preservation of cadaver kidneys. Transplantation 33: 64$68,1982$. 
97 Spector D, Limas $C$, Frost $\pi$, Zachary JB, Sterloff $S$, W1lliams GM, Rolley RT and Sadler JH. Perfusion nephropathy in humean transplants. N Engl J Med 295: 1217-1221, 1976.

98. HA1I GS, Light JA and Perloff Lo. Perfusion-related injury in renal transplantation. Surgery 79: 440-447, 1976.

99. Cerra FB, Raza S, Andres GA and Slegel JH. The endothellal damage of pulsatile renal preservation and lts relationshlp to perfusion pressure and colloid osmotic pressure. Surgery 81: 534-541, 1977.

100. Van der Wi.jk J, Voordes C, RIjkmans BG and Kootstra G. Light mioroscopy findings in intermediate term kidney preservation. Organ Preservation: Basic and Applied Aspects (Ed. DE Pegg, IA Jacobsen and NA Halasz), Lancaster: MTP press, p. 239, 1982.

101. Johnson FWG, Anderson M, Morley AR, Taylor RMR and SWInney J. Twenty-four hour preservation of kidneys injured by prolonesed wam 1schaemla. Transplantation 13: 174-179, 1972.

102. Halasz $\mathrm{NA}$ and Collins GM. Forty-elght-hour ktdney preservation. A comparison of flushing and lce storage with perfuston. Arch Surg 111: $175-177,1976$.

103. Denham BS, IInke CA and Fridd CW. Twenty-four hour cantine renal preservation by pulsatile perfusion, hypothermic storage and comblnations of the two methods. Transplant Proc IX 3: 1553, 1977.

104. Sheenan HL and Davis JC. Renal ischaemia with falled reflow. I Pathol Bacteriol 78: 105-120, 1959.

105. Flores J, DIBona DR, Frega $N$ and leaf A. Cell volume regulation and ischaemic tissue damage. J Membrane Biol 10: 331-343, 1972.

106. Summers WK and Jamison RL. The no reflow phenomenon in renal ischemia. Lab Invest 25: 635-643, 1971.

107. Hardaway CRM, Elovitz CMJ, Brewster WR and Houghin DN. Clotting time of heparinized blood. Arch surg 89: 701-705, 1964.

108. Weed RI, La Cell PI and Mer1LI EW. Metabollc dependence of red cell deformability. J Clin Invest 48: 795-809, 1969.

109. Bergstrom J, Colliste H, Groth $C$, Hultman $E$ and Melin B. Water, electrolyte and metabolic content in cortical tissue from dog kidneys preserved by hypothermia. Proc Eur Dialysis Transplant Ass 8: 313$320,1971$.

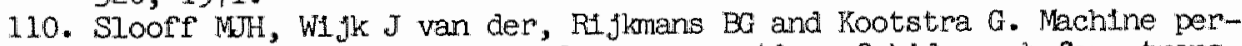
fusion versus cold storage for preservation of kldneys before transplantation. Arch Ch1r Neerl 30: 83-90, 1978.

111. Belzer Fo, Reed TW, Pryor JP, Kountz SL and Dunphy JE. Cause of renal injury in kidneys obtalned from cadaver donors. Surg Gynecol Obstet $130: 467-477,1970$.

112. Flloso AM, Cho SI. Analysis of 75 discarded cadaver kldneys. Arch Surg 111: 1129-1130, 1976.

113. Proctor E. Vascular resistance and urinary flow in the 1schemlo kidney during 48- to 96-hour perfuston. J Surg Res 27: 175-180, 1979.

114. Miller HCh, Alexander JW and Nathan $\mathbb{P}$. Eiffect of warm 1schemic damage on intrarenal distribution of flow in preserved klaneys. Surgery 72: 193-202, 1972.

115. Baxby $K$ and Johnson RWG. Prediction of kldiney viablilty before transplantation. Br J Surg 62: 810-812, 1975 .

116. Grundmann $R$, Bischoff $A$, Albrod $A$ and Pichlnaler $H$. Canine kidney perfusion after various wam ischaemic periods. Organ Preservation II (Ed. DE Pegg and IA Jacobsen) p. 33, Churchill-Livingstone, Edinburgh, London and New York, 1979. 
117. ModgI11 W, Wiggtns PA, Rosenberg II, Humphrey CS and Glles GR. An evaluation of viability tests of human cadaverte kidneys. Br J Surg $54: 548-553,1977$.

118. Feinfeld DA, Levine RD, Levine SD and Fleischner G. Ligandin in perfusates fron transplanted kidneys: a test for tubular necrosis. Nophron 21: $38-41,1978$.

119. Cho 3I, Zallneraltis $B$, Ond $N$ and Arias IM. Prediction of cadaver kidney function by ligandin analys1s. J Surg Res 30: 361-364, 1981.

120. Macallum AB. The paleochemistry of the body fluids and tissues. Phys101. Rev 6: $316,1926$.

121. Doninan FG. Theorle der Membrangleichgewichte und Membranpotentiale bel Vorhandensein von nicht dialysierenden Elektrolyten. Ein Beltrag zur physikalisch-chemischen Pbyslologie. Z. Elektrochem 17: 572, 1911.

122. Nernst $W$. Uber die berechnung chenischer Glelchgewichte aus thermischen Messungen. Nachr Acad WISs Goetingen. Math Physik KI IIa. Math Physik Chem Abt 1: 1, P< 1906.

1.23. Acquatella $\mathrm{H}$, Përez-González $M$, Morales JM and Whittembury G. Ionic and histological changes in the kidney after perfusion and storage for transplantation. Transplantation 14: 480, 1972.

124. Downes G, Hof Prnarm FM, Huang $J$ and Belzer FO. Mechanisms of action of washout solutions for kldmey preservation. Transplantation 16: $46,1973$.

125. States $B$, Holtzapple Ph, Rosenhagen M and Segal S. Effect of hypothermic storage of kidney slices on menbrane ATPases and electrolyte transport. Kidney Int. 2: 17, 1972.

126. Green CJ and Pegg DE. Mechanism of action of "intracellular" renal preservation solutions. World J surg 3: 115, 1979.

127. Southard JI and Belzer Fo. Control of canine kidney cortex slice volume and lon distribution at hypothermia by impermeable anions. Cryobloloby 17: 540, 1980.

128. Belzer FO, Hoffman RM, Glass NR, Sollinger HW and Southard JH. A new perfusate for kıdney preservation. Transplantation 33: 322, 1982.

129. Mees $N$, Southard $\mathrm{JH}$ and Belzer Fo. Inhibition of Lschemic Induced celluzar swelling in kidney cortex tissue by lactoblonate anions. I Trauma 22: 118-120, 1982.

130. Southerd JH, SenzI.S KA, Hoffmann PM and Belzer Fo. Fnergy metabolism In kidneys stored by simple hypothermid.

Transplant Proo 9: 1535, 1977.

131. Southard $\pi \mathrm{H}$, Senzig KA and Belzer Mo. Erfects of hypothermia on canine kt.dney mitochondrla. Cryobiology 17: 148, 1980.

132. BuhI MR and Jörgensen S. Brealkdown of 5-adenine nucleotides in Ischaemic renal cortex estimated by oxypurine excretion durling perfuston. Scand J Clin Iab Invest 35: 211, 1975.

133. Calmen KC, Quin RO and Bel1. PRF. Metabollc aspects of organ storage and prediction of organ viability. Organ Preservation (Ed. DE Pegg) Churchill-Livingstone, London and Fdinburgh, p. 225, 1973.

134. Buhl $\mathbb{M R}$. Oxypurgne excretion during Kidney preservation: An indicatol" of Lschaemic danage. Scand J Clin Lab Invest 36: 169, 1976.

135. Fischer JH, Kulus D, Hansen-Schmidt I and Isselhard W. Adenine nucleotide levels of carine kldneys during hypothermic aeroblo or anaeroble storage in Collins' solution. Eur Surg Res 13: 178, 1981. 
136. Rosis $\mathrm{H}$ and Escott ML. Gaseous oxygen perfuston of the renel vessels as an adjunct in kidney preservation. Transplantation 28: 362, 1979.

137. Wischer JH, Cremtak $A$, Haver $U$ and Isselhard W. A new simple method for optimal storage of ischenically damaged kidneys. Transplantation 25: $43,1978$.

138. Bore PJ, Papatheofanis I and Sells RA. Adenosine triphosphat regeneration and function in the rat kidney following wam 1schaemla. Transplantation 27: 235, 1979.

139. Fernando AR, Griffiths JR, O'Donoghue EPN, Ward JP, Anstrong DMG, Hendry WF, Perrett D and Wickham JEA. Enhanced preservation of the 1schaemic kidney with inosine. Lancet 1: 555, 1976.

140. Buhl MR, Kemp $E$ and Kemp G. Inosine in preservation of rabblt kidneys for transplantation. Thamsplant Proc 9: 1603, 1977.

141. Buhl $\mathrm{NR}$, Kemp $E$ and Kemp $G$. Purine nucleotide and rucleoside admintstration to kidneys: the effect on tolerance to ischaemia. Organ Preservation II (Ed. DE Pegg and IA Jacobsen) Churchtll-IIvingstone, Edinburgh, Iondon and New York, p. 247, 1979.

142. Baue $A E$, Chaudry $I H$, Whrth $M A$ and Sayeed MN. Cellular alterations with shock and ischemla. Anglology 25: 31, 1974.

143. Rey LR. Thermal analysis of eutectios in freezlng solutions. Ann NY Acad Sc1 85: 510-534, 1960.

144. Lovelock JE. The mechenism of the protective action of glycerol against hemolysis by freezing and thawing. Blochem Blophys Acta 11: $28-36,1953$.

145. Lovelock JE. The denaturation of lipid-protein complexes as a cause of damage by freezing. Proc Roy Soc London (B10.1) 145: 427-433, 1957.

146. Mazur P. Causes of injury in frozen and thawed cells. Proc Am Soc Exp B101 24: 175-182, 1965.

147. Mazur $P$. The role of Intracellular freezing in the death of cells cooled at supraoptimal rates. Cryoblology 14: 251-272, 1977.

148. Mergman HTS. Review of biological freezing. Cryobiology, (Ed. HI Meryman) Academic Press, New York, p. 2-114, 1966.

149. Huggins CE. Frozen blood-clinical experlence. Surgery 60: 77-84, 1966.

150. Farrant J, Knight SC, MCGann LE and O'Brian J. Optimal recovery of lymphocytes and tissue culture cells following rapld cooling. Nature 249: $452-453,1974$.

151. Pegg DE. Freezing of bone marrow for clinical use. Cryoblology 1: $64-71,1964$.

152. Sherman JK. Low temperature research on spermatozoa and eggs. Cryobilology 1: 103-129, 1964.

153. Whittingham DG and Adams CE. Low temperature preservation of rabbit embryos. Cryob1ology 11: 560, 1974 .

154. Jacobsen LA. Steps towards long-term preservation of ktaneys at subzero temperatures. Scand J Urol Nephrol suppl. 52, 1979.

155. Pegg DE, Jacobsen LA, Armitage JW and Taylor M. Mechanisms of cryoinjury in organs. Organ Preservation II (EA. DE Pegg and IA Jacobsen) Churchl11-Livingstone, New York, London and Edirburgh, p. 132, 1979.

156. Halasz NA, Rosenfield HA, Orloff $M I$ and Selfert LN. Whole organ preservation, II freezing studies. Surgery 61 : 4.17-421, 1967. 


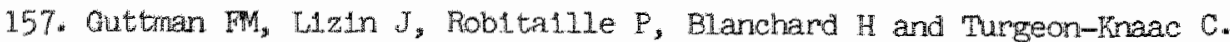
Survival of cargne kidneys arter treatment with dmethyl-sulphoxlde, freezirg at $-80^{\circ} \mathrm{C}$, and thawing by microwave 11 Iumination. CryobloloEY 14: $529-567,1977$.

158. Pegs DE, Green CJ and Walter CA. Attempted canine renal cryopreservation uslrg dimethyl sulphoxide, helitum perfuston and microwave thantng cryoblology 15: 618-626, 1978.

159. Than GM and HIrsch A. Prospects for organ preservation by vitrifleation. Organ Preserwation: Baslc and applled aspects (Ed. DE Pegg. IA Jacobsen and NA Halasz) Lancaater, MTP press, p. 399, 1982.

160. Belzer 70 and Southard J1. The future of kidney presemation. Transplantetion $30: 161,1980$.

161. MIner J and Lakey WH. Kidney preservation using combinations of Belzer and Collins techniques. Transplantation 20: 278, 1975.

162. Scott DF, Stephens EO, Keaveny KV, Kountz SL and Belzer FO. Evaluation of preservation of cadaver kidneys. Transplantation 11: 90 , 1971.

163. Woods JE, Holley KE and DIpasquale JA. Comparison of methods of 24hour preservation of dog Kldneys using the same perfusate. Transplantation 11: 295, 1971.

164. Kootstra $\mathrm{G}$, Van der W1jk J and Pujkmans Ba. A now device towards $1 n-$ temediate tem kldney preservation. An expermental study. Scand J Urol Nephrol 54 (suppl): 86-89, 1980.

165. Van der WIJk J, Slooff MWH, Ri Jknans BG and Kootstra G. Sucicesisful 96- and 144-hour experimental kidney preservation: A combination of standard machine preservation and newly developed nomothermic ex vivo perfuston. Cryoblology 17: 473, 1980.

166. Donker AJM, Wan der Hem, Slulter WJ and Beekhuis H. A radiaisotope method for simultaneous determination of the glomerular flltration rate and the effective renal plasma flow. Neth $\mathrm{J}$ Med 20:97, 1977.

167. 3ntth HW. "The kldney. Structure and function in heal th and disease. New York: Oxfond Unlversity Press, p. 43, 1951.

168. Herman ThJ and Turcotite JG. Preservation of kidneys by hypothemla and low flow perfusion w1th bloodless perfusate. Arch Surg 98* 121, 1969.

169. Scott $J$, Emanuel. D and Haddy F. Effect of potasslum on remal vascular resistance and urlne flow rate. Am J Physlol 197: 305-308, 1959.

170. Powe1] WJ Jr. DIBona DR, Wlores J and Leaf A. Fiffects of hyperosmothe manitol on reduclng ischemlc cell swelling and minimizing nyocardial recrosis. C1rculation 54: 603-615, 1976.

171. Buchbinder D, Karnody AM, Leather RP and Shah DM. Hypertontc mann1tol: Its use in the prevention of revascularisation syndrome after acute artental 1schemia. Arch SurB 116: 414-421, 1981.

172. RAflmans BO, Van der W1jk J, Donker AJM, Sloaff MH and Kootstra $G$. Functlonal studtes in 6 days successful preserved canine kidneys. I Jrol 127: 163-166, 1982.

173. Baltz $\mathrm{T}$, Hallenbeck GA, Shorter RG, Scott GW, Owen ChA and Hunt JC. Preservation of kidneys for transplantation. Arch Surg 91: 276, 1965.

174. Lavender AR, Forland M, Rams JJ, Thompson JS, Russe HP and Spargo BH. Extracorporeal transplantation in man. J A M A 203: 265, 1968.

175. Carter JN, Green RD, Halasz NA and Colilns GM. Ex vivo perfusion: A renal preservation model. I Surg Res 31: 55-60, 1981 . 
176. Pauşescu E, Mendler $N$, Gebhardt $K$ and Sebening F. Exceptional performance in heart preservation with aminoacid contalning perfusion fluid. World I Surg 2: 109, 1978.

177. Van der WIJk J, Rijkmans BG and Kootstra G. Six day kddney preservation in a canine model. Influence of a 1 to $4 \mathrm{hr}$ ex-v1vo perfuston interval. Transplantation 35: 408-411, 1982.

178. Henderson LW, NoIph $\mathrm{KD}$, Puschett JB and Goldberg M. Proximal tubular malfunction as a mechanism for diuresis after renal homotransplantatIon. N Eng J lled 278: 467, 1968.

179. Herdman RC, Vermier RL, Michael AF, Kelly WD and Good RA. Renal function and phosphorus excretion after human renal homotransplantation. Lancet 2: 121, 1966.

180. Herdman RC, Michael AF, Vernier RL, Kelly WD and Good RA. Changes in phosphorus excretion and renal function after human renal allotransplantation. Nephron 5: 170, 1967.

181. Kountz SL, Truex G, Ealey LE and Belzer FO. Serlal hemodynamics after renal allotransplantation in man. Clrculation 41: 217, 1970.

182. Berkow1tz HD, Miller ID, Itskov1tz $\mathrm{HD}$ and Bovẻe KC. Renal function In the 1solated perfused kidney. Surg Gynecol Obstet 127: 1257-1266, 1968.

183. Dobell ARC, Mitri M, Galva R, Sarkozy E and Murphy DR. Btological evaluation of blood after prolonged recirculation through film and membrane oxygenators. Ann Surg 161: 617, 1965.

184. Lee WH $\mathrm{Jr}$, Krumhaar D, Fonkalsmud EW, Schjeck OA and Maloney I Ir. Denaturation of plasma protein as a cause of morbidity and death af"ter intracardiac operation. Surgery 50: 29-38, 1961.

185. Valdes ME, Iandau SE, Shah DM, Newell JC, Scov111 WA, Stratton H, Fhodes GR and Powers SR. Increased glomerular flltration rate following mannttol administration in man. I Surg Res 26: 473-477, 1979.

186. Johnston PA, Bernard DB, Perrin NS and Levinsky NG. Prostaglandins mediate the vasodilatory effect of mannitol in the hypoperfused rat kidrey. at Clin Invest 68: 127, 1981.

187. Conger JD, Robinette $J B$ and Guggenhelm SJ. Effect of acethylcholine on the early phase of reversible noreptnephrine-Induced acute renal fallure. Kidney Int 19: 399-409, 1981.

188. Arendshorst WJ, FIm WF and Gottschalk CW. Pathogenes ls of acute renal failure following temporary renal ischemia in the rat. Circ Res 37: $558-567,1975$.

189. Tiamer GA, Sophasan and Sluan KL. K1dney pressure after temporary renal artery occlusion in the rat. Am J Phys101 230: 1173-1181, 1976.

190. Donohoe JF, Vankatachalam MA, Bernard DB and Levingky NG. Tubular leakage and obstruction after renal Lschaenia: Structure-functional corpelations. Kidney Int 13: 208-222, 1978.

191. Cump FE, Mag111 Th, Thal AP and KInney JM. Regional adrenergle blockade by Intra-arterlal injection of phenoxybenzamine. Surg Gymecol Obstet 127: 319-326, 1968.

192. Blaine FH and Dunlay MC. Renal function during conclousness and anesthesia in sheep: effects of renai vasodilation by papavertne and acethylcholine. J Pharmacol Exp Ther 218: 470-474, 1981.

193. Derkx FHM, Bouma BN and Schaleknamp MADH. Prorenin - renth converston by the contact activation system in human plasma. Role of plasma protease inhibitors. J Lab Clin Med, 1984, in press. 
194. Molff JC and Itskovitz HD. Loss of the renal vasoconstrictor act1vity of anglotensin II during renal ischemia. J Clin Invest 43: 2359-2367, 1964.

195. Fuscher JH, Hansen-Schmldt I, Kulus D and Isselhard W. Renal viab1lity testing during preservation by metabolic parameters.

Ongan Preservation: Besic and applied aspects (Ed. DE Pegg, IA Jacobsen and NA HaLasz) MTP Press, Lancaster, p. 139, 1982.

196. Buhl MR. The post anoxl. regeneration of $5^{\prime}$-adenine-nucleotides in rabblt kidney tissue during in vitro perfusion. Scand J Lab Invest $36: 175,1976$.

197. Chan et al. Acute renal fallure. Ed. Ellahou HE, London: Ltbbey J., $35,1982$.

198. Sulzer FG. Versuch elner Naturgeschichte des Hamsters. 1774. 


\section{SLOTWOORD}

De experimenten beschreven in dit proefschrift werden op drie plaatsen verricht, te weten; Groningen, Luik en Mastricht. Herult volgt dat er vele mensen in meer or mindere mate aan het onderzoek hebben meegewerkt. Het zou onmogelijk zijn om hen allen op deze plaats te bedanken; bij voorbat daarom mijn excuses.

Prof. Kootstra wiI 1 ik in het bljzonder bedakken voor de wIjze waarop hij het onderzoek heeft geleid. Z1 jn onvermoelbaar enthouslasme is een grote stimulans voor mij geweest. Prof. Wildevuur wil ik bedanken voor zijn begeleiding tijdens het eerste deel van het onderzoek. Jan van der W1Jk, het was een groot genoegen om met jou samen te werken. Dr. Donker wil ik special bedanken voor zifn praktische hulp, de verhelderende discussies en de advlezen voor de correetle van dit proefschrift. Chrls Voordes ben ik zeer erkentelijk voor zifn hulp bif het beoordelen van de histologische preparaten. Ook Rob Visser in Mastricht heeft hieraan meegewerkt. Het eerste deel van het onderzoek werd verrlchti in het Centraal Dlerenlaboratorium van de R.U. Groningen. Ik dank hierbij alle medewerkers voor hun uitstekende blotechnische hulp. Tevens bedank ik hierbif de analistes van de afdeling interne en het isotopenlaboratorlum voor het verrichten van de nierfunktie bepalingen.

Een deel van de experimenten werd ultgevoerd in Luik. Prof. N1zet wil ik hierbij bedanken voor zijn gasturijhela en voor het beschlkbar stellen van een bloedpomp. De technische assistentie van de heer en mevrouw Thoumsin-Moons was bijzonder leerzaam.

In 1980 werd het onderzoek op het blomedisch centrum van de R.U. Limburg voortgezet. Wh Bumman heeft mid vele goede adviezen gegeven warvoor ik hem zeer erkentelljk ben. Ton van den Bogaard, Petra Rommers en Hub slmons wll lik bedanken voor hun hulp blj de praktische uitvoering van de experlmenten, evenals Ruud Krager en Inger Slmons van de capac1- 
teltagroep fyslologle. De medewerkers van de instrumentele d1enst op het B.M.C. waren steeds behulpraam buj technlsche problemen, warvoor min hartelijke wank.

Prof. Struyker Boudlet heeft door zijn adviezen bljgedragen aan het ultelndel1jke onderzoeksresultat. ook voor de kitische beoordeling van het proefschift ben $1 k$ hem zeer erkente $11 \mathrm{Jk}$.

Chrls Voskamp en de medewerkers van de medische fotografle bedank $1 k$ woon hun hulp bly het maken wan de tekeningen en foto's. Prof. Greep wil $1 \mathrm{k}$ bedanken voor de gelegenheld die his als opleider geboden heeft om att proefschrift te voltoolen. Tenslotte wil Ik Karin Spronck harte$11 \mathrm{lk}$ bedanken voor het typewerk. Met bewonderenswardig ulthoudingsvermogen heeft zij steeds opnieuw de vele correctles in dit proefschift aangebracht. 


\section{CURRICULUM VITAE}

Bert Rijkmans werd geboren op 6 juni 1953 twe Groningen. Van 1965 tot 1971 volgde hiy zifn middelbare schoolopleiding aan het Praedinius Gymnasium te Groningen. Na het behalen van het elndaploma (B) ging hif medicijnen studeren aan de Rijlcsuniversiteit Groningen, waaraan hil in 1978 het arts-examen behaalde. Daarna was hil tot 1980 als wetenschappelf jk medewerker verbonden aan deze universitelt bij de afdeling Experimentele Chlrurgle (hoofd Prof. Dr. C.R.H. W1Idevuur). Van 1980 tot 1981 was hif werkzaam als wetenschappelifk medewerker aan de Rijksuniversiteit Limburg te Mastricht bif de capaciteltsgroep Algemene Heelkunde. In de periode 1978 tot 1981 werd experlmenteel nierpreservatie onderzoek verricht, gesubslaleerd door de Nier Stichting Nederland. Vanaf januart 1982 volgt hif de opleiding Algemene Chlrurgie in het Zlekenhuls St. Annadal (opleider Prof. Dr. J.M. Greep). 